\title{
The Role of Prison Chaplains in Restorative Justice
}

\author{
by \\ Jurgita Rushkyte, B.A. Hons \\ A thesis submitted to \\ the Faculty of Graduate Studies and Research \\ in partial fulfillment of \\ the requirements for the degree of
}

Master of Arts

\author{
Department of Law \\ Carleton University \\ Ottawa, Ontario \\ January, 2007
}

(C) 2007, Jurgita Rushkyte 


$\begin{array}{ll}\begin{array}{l}\text { Library and } \\ \text { Archives Canada }\end{array} & \begin{array}{l}\text { Bibliothèque et } \\ \text { Archives Canada }\end{array} \\ \begin{array}{l}\text { Published Heritage } \\ \text { Branch }\end{array} & \begin{array}{l}\text { Direction du } \\ \text { Patrimoine de l'édition }\end{array} \\ \begin{array}{l}\text { 395 Wellington Street } \\ \text { Ottawa ON K1A ON4 }\end{array} & \begin{array}{l}\text { 395, rue Wellington } \\ \text { Ottawa ON K1A ON4 } \\ \text { Canada }\end{array}\end{array}$

Your file Votre référence ISBN: 978-0-494-26966-4 Our file Notre référence ISBN: 978-0-494-26966-4

NOTICE:

The author has granted a nonexclusive license allowing Library and Archives Canada to reproduce, publish, archive, preserve, conserve, communicate to the public by telecommunication or on the Internet, loan, distribute and sell theses worldwide, for commercial or noncommercial purposes, in microform, paper, electronic and/or any other formats.

The author retains copyright ownership and moral rights in this thesis. Neither the thesis nor substantial extracts from it may be printed or otherwise reproduced without the author's permission.
AVIS:

L'auteur a accordé une licence non exclusive permettant à la Bibliothèque et Archives Canada de reproduire, publier, archiver, sauvegarder, conserver, transmettre au public par télécommunication ou par l'Internet, prêter, distribuer et vendre des thèses partout dans le monde, à des fins commerciales ou autres, sur support microforme, papier, électronique et/ou autres formats.

L'auteur conserve la propriété du droit d'auteur et des droits moraux qui protège cette thèse. $\mathrm{Ni}$ la thèse ni des extraits substantiels de celle-ci ne doivent être imprimés ou autrement reproduits sans son autorisation.
In compliance with the Canadian

Privacy Act some supporting forms may have been removed from this thesis.

While these forms may be included in the document page count, their removal does not represent any loss of content from the thesis.
Conformément à la loi canadienne sur la protection de la vie privée, quelques formulaires secondaires ont été enlevés de cette thèse.

Bien que ces formulaires aient inclus dans la pagination, il n'y aura aucun contenu manquant.

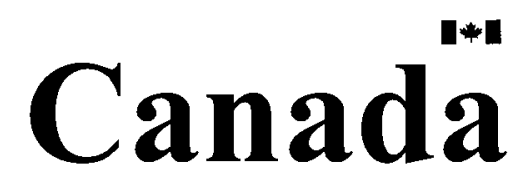




\begin{abstract}
Modern practices of restorative justice have garnered considerable academic attention since the $1970 \mathrm{~s}$. While various facets of the different practices that fall under the "restorative justice" umbrella have come under the lens of academia and corrections research, there remains a dearth of study of the interrelation between restorative justice and prison chaplaincy.

This thesis explores the links between restorative justice and prison chaplaincy. The two-pronged approach begins on a conceptual level, that is, by examining the similarities of the goals and practices of restorative justice and prison chaplaincy, thereby highlighting their natural complementarity. Secondly, the role of prison chaplains as active, intentional participants in some restorative justice settings is examined with a view to further shedding light on the complementary natures of both approaches. It is argued that there is a natural complement between prison chaplaincy and the main elements, principles and practices of modern restorative justice as these are developed in the existing literature of the field.
\end{abstract}




\section{Table of Contents}

Title Page

Abstract

Table of Contents

i

ii

iii

Chapter 1: Introduction

Research Focus and Thesis Statement 3

Key Concepts and Terms

$\begin{array}{ll}\text { Methodology } & 10\end{array}$

Chapter 2: Historical Overview 19

The Evolution of Restorative Justice in the Western World 20

Pre-modern and Indigenous "restorative" practices 23

History of the modern restorative justice movement in Canada 33

$\begin{array}{ll}\text { Origins of prison chaplains } & 39\end{array}$

$\begin{array}{ll}\text { History of prison chaplains } & 40\end{array}$

Prison chaplains today 44

Historical confluence of motivations? 45

Chapter 3: Overview of Restorative Justice Theory 47

$\begin{array}{ll}\text { Defining restorative justice } & 48\end{array}$

Affected persons $\quad 52$

Main principles of restorative justice $\quad 61$

$\begin{array}{ll}\text { Goals of restorative justice } & 68\end{array}$

Some hallmarks of an effective restorative justice practitioner in the prison $\quad 69$

setting

Chapter 4: Restorative Justice Role of Prison Chaplains $\quad 72$

$\begin{array}{ll}\text { General role and mandate of prison chaplains } & 73\end{array}$

Prison chaplains and restorative justice: the conventional setting $\quad 81$

Formal participation of prison chaplains in restorative justice 107

$\begin{array}{ll}\text { Chapter 5: Conclusion } & 115\end{array}$

$\begin{array}{ll}\text { Future research } & 115\end{array}$

$\begin{array}{ll}\text { Limitations } & 116\end{array}$

$\begin{array}{ll}\text { Interpreting the findings } & 116\end{array}$

$\begin{array}{ll}\text { Bibliography } & 120\end{array}$

$\begin{array}{ll}\text { Appendix A } & 131\end{array}$

$\begin{array}{ll}\text { Appendix B } & 135\end{array}$ 


\section{Chapter 1: Introduction}

Chaplains play a vital role in the prison environment, yet these prison employees do not receive adequate attention in academic literature. ${ }^{1}$ Little is written about them in the context of prevailing and emergent correctional trends. Even with the emergence of restorative justice as a near-mainstream corrections alternative and its broad explication in academic and policy circles, inadequate attention is devoted to the juxtaposition of prison chaplaincy and restorative justice. I aim to bridge this gap.

There are many questions surrounding prison chaplains. What are they and what exactly do they do? Why is there so little attention paid to their work? Why has so little research been done regarding chaplains' work and their impact on the penitentiary legal system? This thesis will aim to shed light on these and other questions by honing in especially on the relationship between the work of prison chaplains and the emergent restorative approach to criminal justice.

Even though modern restorative justice is a comparatively new phenomenon, it has nonetheless garnered a much greater portion of recent academic attention compared to that which is devoted to prison chaplains. There remains much to learn in this emergent field, but many of its bases are covered. It has been considered from all angles, or so it would seem. One notable and perhaps puzzling exception is that of prison chaplains. For an approach that stresses inclusiveness and participation of a wide range of individuals (this will be discussed further on), it is peculiar that many of its scholars in restorative justice such as Bazemore, Braithwaite, Cooley, Daly, Estrada-Hollenbeck,

\footnotetext{
'Sundt, J. L. and Cullen, F.T., "The Correctional Ideology of Prison Chaplains: A National Survey," (2002) 30, Journal of Criminal Justice at 370.
} 
Hudson, Pranis and others, have been silent on chaplains as prospective partners in the prison setting.

Why?

Perhaps the lack of attention paid to prison chaplains stems from the fact that the details of life in prison are not typically of concern to the general public, including academia. The reality is that prisons are closed systems and even prison reforms, though technically matters of public policy, are closed-system initiatives and are rarely, if ever, "spurred by community input." It should not be a surprise then that prison employees in general do not figure prominently on the minds of the general public. ${ }^{3}$ The problem is compounded for prison chaplains, who comprise less than 1 per cent of all prison employees. ${ }^{4}$ These factors combine to render them unnoticed and their work relatively unexamined. Their high turnover rates further complicate their systematic study.

In spite of the dearth of academic insight into prison chaplains, closer attention to prison chaplains, especially in relation to restorative justice, may be valuable for several reasons from a socio-legal standpoint. Historically, the responsibility of prison chaplains has been to provide prisoners with a variety of services, such as facilitating adjustment to prison, visiting prisoners in isolation, helping inmates make plans for their release, counseling and helping inmates' families, providing religious and general education, and, of course, conducting religious services. ${ }^{5}$ The work of chaplains goes beyond the offender in prison, and in some cases extends to his/her family, the victim of the crime

\footnotetext{
${ }^{2}$ Bazemore, G., "Restorative Justice and Earned Redemption: Communities, Victims and Offender Reintegration," American Behavioral Scientist, vol. 41, no. 6 (March 1998) at 775.

${ }^{3}$ Sundt and Cullen, at 370.

${ }^{4}$ Ibid.

${ }^{5}$ Ibid.
} 
and his/her family, and the community at large. ${ }^{6}$ Furthermore, it is known that "chaplains have historically played a role in shaping correctional policy, have advocated for reform, and have occasionally raised an intra-institutional voice against inhumane practices." Likewise, "the potential importance of the [prison] chaplain as an agent of social change" has not gone unnoticed. ${ }^{8}$ As an example, a book by Glaser entitled The Effectiveness of a Prison and Parole System, “...of the successful releasees who credited a specific staff member with being a major influence in their reformation, one-sixth [of inmates] cited the prison chaplains. ${ }^{9}$ For all of these reasons, it would seem that, if anyone, prison chaplains are well placed to make an impact on prisoners. If that is indeed the case, how do their work and aspirations match up with the goals and principles that underpin restorative justice? Is there a natural, untapped synergy between prison chaplaincy and restorative justice?

\section{Research Focus and Thesis Statement}

Even though chaplains have been a part of the prison system since its inception, their work remains obscure to outside observers. This research will shed some light on the work and the significance of prison chaplains by examining their correctional approach and their role in the penitentiary system in Canada, in general, at the federal and provincial levels. At its heart, this research will explore the likely relationship between

\footnotetext{
${ }^{6}$ McCormick, K., "Prison Chaplains' Conference Hears a New Definition of Justice," (From the Worldwide Faith News Archives: www.wfn.org/2000/06/msg00018.html) at 1.

${ }^{7}$ Sundt and Cullen, "The Correctional Ideology of Prison Chaplains: A National Survey" (2002) 30, Journal of Criminal Justice, at 370.

${ }^{8}$ Ibid.

${ }^{9}$ Glaser, D., The Effectiveness of a Prison and Parole System, (The Bobbs-Merrill Company, Inc. University of Illinois, 1964) at 145.
} 
the work of prison chaplains and modern restorative justice, which is a new approach to criminal justice that has even spawned a government-run program in and out of prisons.

The purpose of linking prison chaplaincy and restorative justice in this research study derives from the fact that in spite of what may seem like a natural complemetarity, few authors have compared the work of prison chaplains with the main tenets of restorative justice. For this reason, there is an unfulfilled need in the socio-legal context to bridge the gap between prison chaplaincy and restorative justice.

The thesis question is twofold. First, is there a general complement between chaplaincy and restorative justice pertaining to their purpose and modus operandi in the prison environment? Second, what is the role, if any, of prison chaplains in the process of restorative justice? In the process of answering the main questions, other subquestions will be raised and answered, such as: what is restorative justice? What is the role of restorative justice in prisons? Why has the link between prison chaplains and restorative justice not been studied in-depth? And finally, why is it important in a sociolegal context to find correlations between prison chaplains and restorative justice?

The answers to each of these questions and sub-questions point to the overall argument (thesis) of this research project, that is, by the very nature of the office of the prison chaplain, there is a natural complement between prison chaplaincy and the main elements, principles and practices of modern restorative justice as these are developed in the existing literature of the field.

Given that a large proportion of prison chaplains are Christian faith, the academic literature on prison chaplains is also mainly written from Christian perspective, thus this thesis paper will for the most part deal with the work of Christian chaplains. While 
acknowledging this limitation, the work of chaplains of other faith traditions will also be acknowledged and discussed vis-à-vis restorative justice, albeit in a more restricted manner, leaving open directions for future research.

\section{Key Concepts and Terms}

For the purpose of clarity, it is important to identify and define the key concepts that will be used extensively in this thesis paper.

\section{Institutions}

The terms "prison," "jail," "penitentiary," "detention centre" and "correctional centre" are used throughout the thesis and are used frequently during the interviews. While there is a tendency for people to use these terms interchangeably, it is important to recognize that there are some important differences between their proper meanings. The main distinguishing features among these different terms pertain to the function, duration of incarceration and level of governmental jurisdiction. More specifically, both jails and detention centres function primarily to hold accused persons pending trial, sentencing or other court proceedings. ${ }^{10}$ Jails and detention centres may also hold people who have been assigned short sentences. ${ }^{11}$ Jails are typically smaller, older, local facilities, while detention centres by comparison are larger, modern, regional facilities built to meet the requirements of several municipalities. ${ }^{12}$ Correctional centres house offenders normally

\footnotetext{
10 "Correctional Services: Frequently Asked Questions," Ministry of Community Safety and Correctional Services, http://www.mpss.jus.gov.on.ca/english/corr_serv/faqs_correctional_services.html.

"Ibid.

${ }^{12}$ Ibid.
} 
serving periods of incarceration of up to two years less a day. ${ }^{13}$ Penitentiaries are federal government-run institutions. The term prison can apply to any of the above, except perhaps for jail, as "prison" implies an institution for incarceration for periods longer than the immediate term.

In Canada, the penal correctional system is divided into two jurisdictions: the provincial and federal. The provincial correctional system is responsible for sentences that are two years less a day, while sentences that are two years and more fall under the umbrella of the federal correctional system.

\section{$\underline{\text { Restorative justice }}$}

Defining restorative justice is an onerous task, given the complexity of the concept and its broad, varying application. At this juncture, I provide a succinct definition and return later on to indulge in the details in Chapter 3, where I compare competing definitions and present in detail the main elements of restorative justice for the purpose of delimiting a theoretical framework for the ensuing analysis in Chapter 4.

Basically, "restorative justice" is "a process whereby all the parties with a stake in a particular offense come together to resolve collectively how to deal with the aftermath of the offence and its implications for the future."14

Restorative justice takes the form of a variety of practices, of which the most common in Canada are victim-offender mediation (VOM), community and family group conferencing, sentencing circles and community boards or panels.

\footnotetext{
13 Ibid.

${ }^{14}$ Hadley, M. L., "Introduction: Multifaith Reflection on Criminal Justice" in The Spiritual Roots of Restorative Justice, (State University of New York Press, 2001) at 9.
} 
Victim-offender mediation. In victim-offender mediation and related (victim-offender reconciliation) programs, the offender and victim are brought together voluntarily in the presence of a trained mediator, ${ }^{15}$ with whom they meet individually first and then with each other only when they are both ready. ${ }^{16}$ Before the offender and victim do meet, they work with the mediator individually and proceed with the meeting only when each party agrees to proceed. ${ }^{17}$ Referral into the process can happen at one of four main intervals following an offence: upon arrest ("pre-charge"), post-charge but pre-trial, at the sentencing stage or following incarceration but before release. ${ }^{18}$ Regardless of the stage of the intervention, close cooperation with the formal justice system is a must. ${ }^{19}$ In some cases where the session takes place before sentencing, a report from the session is submitted to the court for consideration during sentencing. ${ }^{20}$

Community and family group conferencing. Community and family group conferencing, also known as community justice forums, ${ }^{21}$ has a slightly broader focus than victim-offender mediation. Here, a mediator gathers together the family and friends of both the victim and the offender for a discussion on the appropriate ways to address the offending behaviour and the preferred outcomes for the families involved or the community. ${ }^{22}$ The impact of the offender's behaviour on the victim, the victim's family,

\footnotetext{
${ }^{15}$ Transforming Relationships Through Participatory Justice (Ottawa: Law Commission of Canada, 2003) at 36 .

${ }^{16}$ Zehr, H., The Little Book of Restorative Justice, (Intercourse: Good Books, 2002) at 47.

${ }^{17}$ Ibid.

${ }^{18}$ Transforming Relationships Through Participatory Justice (Ottawa: Law Commission of Canada, 2003) at 36.

${ }^{19} \mathrm{Ibid}$

${ }^{20}$ Ibid. at 37 .

21 "Restorative Justice in Canada: A Consultation Paper," Department of Justice, Canada, May 2000, http://canada.justice.gc.ca/en/ps/voc/rjpap.html.

${ }^{22}$ Law Commission of Canada, 2003 at 39.
} 
the offender's family and the community is assessed..$^{23}$ A plan is formulated for monitoring the future behaviour of the offender and for outlining reparation. ${ }^{24}$ As with victim-offender mediation, various conferencing models have been adapted to the prison setting. ${ }^{25}$

Sentencing circles. "[T]he circle has long been viewed as a symbol of importance and empowerment among many First Nations. ${ }^{26}$ During the sentencing circle ${ }^{27}$ session participants sit in a circle. They are permitted to speak one at a time in the order in which they are seated. ${ }^{28}$ One or two "circle keepers" function as facilitators of the session and, in Aboriginal circles, Elders play a prominent leadership role. ${ }^{29}$

The process, usually several hours, involves gathering and responding to information, and formulating an appropriate sentencing plan that typically contains elements of reparation and restitution. ${ }^{30}$ Family, friends and community involvement provides strong social support and is a strong motivation for the offender to comply with this sentencing plan, lest he/she let all of these people down. The plan typically contains elements of reparation and restitution to the victim, as well as a strategy for the

\footnotetext{
23 Ibid.

24 Ibid.

${ }^{25}$ Newell, T., "Restorative Practice in Prisons: Circles and Conferencing in the Custodial Setting," International Institute for Restorative Practices, August, 2002 http://restorativepractices.org/library/mn02/mn02_newell.html.

${ }^{26}$ Dickson-Gilmore, J., and La Prairie, C., Will the Circle be Unbroken? Aboriginal Communities, Restorative Justice, and the Challenges of Conflict and Change, (University of Toronto Press, 2005) at131. ${ }^{27}$ For a detailed account of an actual sentencing circle in Canada, see Charles Pollard, "Victims and the Criminal Justice System: A New Vision," Criminal Law Review, January, 2000 at 12-16.

${ }^{28}$ Zehr, 2002 at 51 .

29 Ibid.

${ }^{30}$ Robin J. W., Huculak, B. and McWhinnie, A., "Restorative Justice Innovations in Canada," Behavioral Sciences and the Law, no. 20 (2002) at 366.
} 
rehabilitation and integration of the offender. It is rare for judges to refuse the recommended plans. ${ }^{31}$

The victim also experiences much support during the proceedings and is at liberty to express the harm that was done to him/her and seek answers to questions related to the infliction of the harm. Naturally, the victim receives the satisfaction of hearing the offender repent and, in this way, his/her healing and that of the offender and community can get underway. ${ }^{32}$

Variations of the sentencing circle can be applied in the prison setting. The circle is particularly relevant as an alternative process for disciplinary hearings which, according to Newell, form a critical focus of many prison systems. ${ }^{33}$

Community boards or panels. This approach involves boards/panels drawn up from community volunteers. These panels facilitate a discussion between victims and offenders through formal meetings. ${ }^{34}$ This may occur as a pre-charge measure or as a means to determine an appropriate sentence following a guilty plea entered in court. ${ }^{35}$ In either case, the discussion leads to a mutually agreed upon contract setting out the offender's obligations during a probationary period, which typically revolve around reparation and responsibility-taking. ${ }^{36}$ Breaches of the contract result in the offender returning to court for sentencing. ${ }^{37}$ This particular model of restorative justice, or variations of it, perhaps finds less application in the prison setting.

\footnotetext{
${ }^{31}$ Ibid.

${ }^{32}$ Ibid.

${ }^{33}$ Newell, 2002.

${ }^{34}$ Wilson et al, 2002 at 42.

${ }^{35}$ Ibid.

${ }^{36}$ Ibid.

${ }^{37}$ Ibid.
} 


\section{Methodology}

In the process of this qualitative research project, personal narratives of prison chaplains, other people involved in the correction of prisoners, restorative justice experts and relevant community members were recorded. In some cases, these testimonies consisted of letters written to prison chaplains or volunteers and were provided to me well after the fact. Overall, the interviews and other accounts used in this research project provided a body of data shedding light on the links between prison chaplains and restorative justice.

It is perhaps appropriate at the outset to address the issue of selection bias vis-àvis the letters from prisoners to chaplains and volunteers, recognizing the potential for concern that these letters, because they were provided by prison chaplains and chaplaincy volunteers, do not represent the whole experience in prison and possibly cast prison chaplains in an overly positive light. The point may be true, but I believe that its relevance is debatable. I do not dispute the notion that the letters do not represent the whole experience in prison, but they are not meant to. To explain, I am not extracting from them quantitative data for the purpose of assembling statistics to illustrate overall sociological trends. Rather, I am pin-pointing certain qualitative data that illustrate realworld examples of a relationship between the elements of restorative justice and prison chaplaincy. Furthermore, because the thesis is about the relationship of prison chaplains and restorative justice, and not whether prison chaplains are good or bad, positive or negative, it is not entirely relevant that my data comes from primary sources which on the balance cast prison chaplains in a positive light. After all, not all restorative justice experiences are painless for offenders or are perceived by them to be positive. 


\section{Historical overview}

The full analysis of the data will be preceded by a historical overview in Chapter two. This overview will cover several inter-related items of central pertinence to this thesis paper. To the extent that is relevant, the historical roots of the Canadian penal system will be reviewed with an eye on the historical influences that persist to this day. Likewise, the concept of punishment in Canada will be discussed from a historical perspective. This will include an overview of the main goals of the penal system, including the conception and practice of rehabilitation. Furthermore, the rise of restorative justice in Canada will be reviewed. This will include a discussion of both the historical and religious/spiritual roots of restorative justice and the current understanding of restorative justice within the Canadian penal system. Lastly, this chapter will briefly look at the historical roots of prison chaplaincy in Canada and its evolving role over time.

\section{$\underline{\text { Research Participants }}$}

For the purpose of this research project, two separate groups of participants were selected to participate in an interview. Each group consisted of 5 interviewees for a total of 10 people.

The first group of participants was selected for their direct knowledge of the work and experience of prison chaplains with prisoners inside and outside of the prison, at the federal and provincial levels. This group of participants is crucial to the research project since they play a significant role within the penitentiary justice system boundaries and beyond. Their work is greatly understudied, and therefore they provide new insights into the chaplain's profession and their active role in the promotion of restorative justice. The 
main criterion was their employment as prison chaplains in Canada, or their participation as prison chaplaincy volunteers. Those with experience in federal and/or provincial institutions were consulted. Chaplaincy programs in each jurisdiction provide the same services. ${ }^{38}$ The main differences between the prisons of each jurisdiction are the separate bodies of legislation that establish and govern the institutions ${ }^{39}$ and the tenure of the sentences (as discussed earlier, sentences under two years are served in provincial institutions and those over two years are served in federal institutions). The latter facet has implications for the work of prison chaplains, given that those whom they respectively minister to have different needs stemming both from the severity of their offences, as well as the duration of their sentences.

Among this same group of participants were some that are employed as full-time prison chaplains and others that provide chaplaincy services to the prison community on a part-time basis. Each set follow the same policies, procedures and ethical guidelines, however there is a notable distinction the two that deserves attention. Full-time prison chaplains, as the title suggests, are fully employed within the prison setting and have less opportunity for professional interaction with communities outside of prison, therefore, fewer linkages with the community. Part-time chaplains, though less-connected to the prison community, have much more robust ties to the outside community.

The second group of participants consisted of project officers, executive directors, directors, including but not limited to, those that work on the issue of restorative justice.

\footnotetext{
${ }^{38}$ Ministry of Public Safety and Security (Ontario), Correctional Services Division, "Religious Services and Spiritual Care," in Adult Institutions: Policy and Procedures Manual, (July 2004); and Correctional Service of Canada, Role of Chaplains, http://www.csc-scc.gc.ca/text/prgrm/chap/pro06-2_e.shtml. ${ }^{39}$ Ministry of Public Safety and Security (Ontario), Correctional Services Division, "Religious Services and Spiritual Care," (July 2004); and Department of Justice Canada, Corrections and Conditional Release Act (1992), http://laws.justice.gc.ca/en/showtdm/cs/C-44.6///en.
} 
These persons were selected from various Government departments and nongovernmental organizations such as the Law Commission of Canada, the Correctional Service of Canada and Ontario Multifaith Council, all located in the Province of Ontario. I interviewed people who work in the restorative justice units of these organizations. They were selected for their professional expertise in the area of restorative justice and their ability to offer a non-academic perspective grounded in real-world experience.

\section{$\underline{\text { Recruitment Process }}$}

The selection process for this research study was non-random, specifically geared toward persons and centres of expertise in prison chaplaincy and/or restorative justice. Though constrained to some degree by personal availability and other factors, I was nonetheless able to recruit an appropriate cross-section of expertise: Ottawa area prison chaplains, including various employees and/or volunteers from the Ottawa Carleton Detention Centre; representatives from the Law Commission of Canada; officials from the Correctional Services Canada; members of the International Prison Chaplain's Association; a representative of Mentorship Aftercare Presence (M.A.P.); a representative of the Ontario Multifaith Council; and persons from other non-governmental organizations (NGOs). Potential participants were contacted by phone and written letters, through local contacts and governmental offices.

Through various Internet sites, I selected a list of organizations and people, and made contact with local prison chaplains and persons working in the government departments that are related to restorative justice and wrote official letters requesting interviews (please see appendices). Ideally, I was interested in interviewing former 
and/or present prison chaplains of different faiths due to the multi-faith prison environment of Canadian prisons, yet at the same time realized that it may not be possible or practical (if my research was to remain unskewed and representative of the demographic) to interview a chaplain of every faith. For example, according to the Correctional Service of Canada, in 2002 there were approximately 84 Institutional and Community Chaplains in the federal system of corrections alone. ${ }^{40}$ Of these, approximately 50 are Roman Catholic and the remainder, for the most part are Christians of other denominations, two Muslims, and one or two Sikhs, Jews and Buddhists. ${ }^{41}$ These circumstances required me to limit the scope of my research to prison chaplains that are primarily of Christian faith, though I did receive substantial information from a prison chaplain of the Buddhist tradition. However, I should be clear that I solicited and welcomed the participation of prison chaplains of other faiths as well. Overall, I asked prison chaplains questions that are related to their work inside and outside the prison walls, as well as their roles in restorative justice (please see appendices).

In general, the selection process for both groups was both formal and informal involving verbal and written contact with prison chaplains on the one hand and people working and participating in the implementation of the principles of restorative justice on the other. There was no financial gain for those who participated in this study, however, they will be provided with a copy of the finished project per their request.

\footnotetext{
${ }^{40}$ Landry, M., Private consultation by the author (CSC), November 22, 2005.

${ }^{41}$ Ibid.
} 


\section{$\underline{\text { Risks }}$}

The risk level for this research project was likely very minimal to both groups of participants as the nature of this research area is non-partisan, non-controversial and open to public debates and local media coverage.

For Group A: Although very minimal, it is important to note that there might have been (emotional, psychological and professional) risks of partaking in this study. During the course of the interview, prison chaplains, were asked questions about their own personal contact with the inmates and/or their families and how they have dealt with these issues outside the prison walls. This had the potential of being emotionally and psychologically exhausting. While such circumstances were not encountered, I was prepared to offer the participant an option to end the interview or to take a pause in the interview.

Also, it is important to note that the level of confidentiality between chaplain and inmate cannot be breeched. According to the Statement of Ethics, one of the core guiding principles that prison chaplains affirm to is "the importance of respecting the confidential nature of privileged information received during spiritual counsel.",42 Therefore, as the primary researcher, I did not seek information that would breech that pastoral and ethical confidentiality.

For Group B: Also worthy of attention was the very minimal possibility of professional (social and economic) risk involved for executive directors, directors, and project officers who participated in this study. In a case where specific opinions are made public by the

\footnotetext{
42 "Statement of Ethics," Correctional Service of Canada, http://www.cscscc.gc.ca/text/prgrm/chap/soe_e.shtml.
} 
aforementioned professionals, that are at variance with the policy of their employer, there is a possibility for job-related repercussions. For instance, if a person expressed negative feelings, personal perspectives and spoke candidly about the current justice system and/or the process of restorative justice in Canada, there could be negative implications for individual job security and professional relationships may also be affected.

\section{Anonymity/Confidentiality of Participants}

Due to the nature of this research study and since issues concerning the work of prison chaplains, government employees and other participants that work on initiatives of restorative justice are public, it is important to note that I was not be able to offer anonymity to participants of this study.

As primary researcher, I was not able to offer anonymity, as the area of interest is fairly narrow and the community of experts with whom I consulted is also small and opinions expressed by one individual could be recognized by colleagues. However, I was mindful of the potential risks participants were taking and conducted my work as conscientiously and confidentially as possible. I took extra steps to limit public exposure for participants who requested that such steps be taken, such as choosing a place for the interview in a non-public place, that is, somewhere private where the participant felt comfortable. I asked the participant for permission to interview and to record their voices. As per participants' request, confidentiality was respected and ensured however, quotations and comments were documented in the final version of this research project. In cases where participants did not wish for certain comments or ideas to be part of my thesis, I was prepared to make sure to omit such information. 


\section{Analysis}

The interviews took a maximum of 60 minutes and the questions were open-ended to allow each participant to express his/her opinion, personal experiences and to allow more room for discussion. Once the interviews were transcribed by me, key themes and concepts were identified and discussed in the subsequent chapters of this thesis.

In Chapter three, a theoretical framework consisting of the main elements of restorative justice will be devised based on the work of a number of different experts in the area of restorative justice. The analysis of restorative justice on an international scale will be omitted due to the limited scope of this research. The main aim of this chapter is to review and summarize the main theoretical underpinnings of restorative justice together with its main elements and to examine whether there is any commonality among differing definitions. The resulting theoretical framework will in Chapter 4 serve as the analytical basis for examining the data collected during the interviews, the purpose of which is to assess the natural complement between prison chaplaincy and the main elements, principles and practices of modern restorative justice.

Drawing upon the theoretical framework devised in Chapter three, Chapter 4 will evaluate the restorative justice role of prison chaplains by evaluating the data collected during interviews and from other primary and secondary sources. Specifically, the central question of whether prison chaplains engage in the major elements of restorative justice will be answered. How they do so will also be discussed by reviewing their duties, responsibilities and services. It is in this chapter that the thesis will gain full affirmation. 
Chapter five will provide a summary and conclusions including a restatement of the thesis. 


\section{Chapter 2: Historical Overview}

In this Chapter, I provide a relevant historical overview of restorative justice and prison chaplaincy in the Canadian system. Restorative justice proves harder to define than prison chaplains, because "restorative justice" is a relatively new term coined for a set of approaches of multiple origins that have been brought together (with important modifications) under a single umbrella term. Prison chaplaincy, on the other hand, is a lot easier to pin down, both conceptually and in terms of its agents: prison chaplaincy is a faith-based prison ministry and its agents are prison chaplains and ministry volunteers.

I look at the historical roots of both restorative justice and chaplaincy in this chapter to shed light on the commonalities that they share. This chapter discusses the motivations that traditionally have underpinned each, showing that both restorative justice and prison chaplains endeavour toward many of the same ends. My claim is that prison chaplaincy is in practice conducive to the goals of restorative justice, or, as formulated in the introduction, there is a natural complement between prison chaplaincy and the main elements, principles and practices of modern restorative justice. This chapter will show how restorative justice and prison chaplaincy came about. The coincidental commonality of their motivations (in certain respects) will at least prove that they are not mutually opposed. More significantly, it will lend additional support to the evidence provided in Chapter 4.

I begin the chapter by looking at the history of restorative justice including both its Indigenous and Western roots. Next, I look at the various traditions from which the modern restorative justice movement draws its insights and inspirations, focusing mostly on the motivations behind each. My overview of restorative justice is followed by a 
study of the origins of prison chaplains. However, most of this overview will focus on prison chaplains in the context of early Canadian prisons (jails, penitentiaries, reformatories, etc.). Again, the effort will be to gather the early motivations behind the emergent ministry.

\section{The Evolution of Restorative Justice in the Western World}

Many in the field present restorative justice as a traditional approach to justice that predates written history, one that is preserved by the various Indigenous groups that continue to practice it and has only fairly recently been discovered by modern, Western criminal justice systems. For instance, Morris and Gelsthorpe refer to the fact that restorative justice has been in existence for a long time, noting its links with the traditions of Indigenous peoples, ${ }^{43}$ which will be discussed in more detail later in the chapter. Howard Zehr, who has been called "a grandfather of restorative justice" 44 by the Centre for Justice and Peace Building, Eastern Mennonite University and who is "known worldwide for his pioneering work in transforming our understandings of justice"45 notes that restorative justice "is not a new or North American development" and indicates that it owes much to earlier movements and traditions that serve as precedents and are "as old as human history.",46

Not everyone shares the view that restorative justice is a phenomenon with deep historical roots. There is some tendency to see restorative justice as a relatively new

\footnotetext{
${ }^{43}$ Morris, A., and Gelsthorpe, L., "Something Old, Something Borrowed, Something Blue, but Something New? A comment on the prospects for restorative justice under the Crime and Disorder Act 1998," The Criminal Law Review (2000) at p.18.

${ }^{44}$ Eastern Mennonite University. Center for Justice and Peace Building, http://www.emu.edu/ctp/littlerj.html.

${ }^{45}$ Ibid.

${ }^{46} \mathrm{Zehr}, \mathrm{H}$., The Little Book of Restorative Justice (Intercourse: Good Books, 2002) at 11-12.
} 
movement that "began as isolated criminal justice initiatives based on reconciliation rather than retribution" that "embrace a broad range of approaches," including (but limited to) those drawn from various ancient and Indigenous traditions. ${ }^{47}$ Even Zehr acknowledges that the modern field of restorative justice came about in the 1970 s through case studies that involved experiments with victim-offender encounters. ${ }^{48}$ Daly contends that the notion that restorative justice employs Indigenous practices and was the predominant form of justice in pre-modern times is a myth, ${ }^{49}$ constructed and promulgated by some proponents of restorative justice in order to lend credibility to their policy goals. ${ }^{50}$ She argues that this is concerning; noting that the individual uniqueness of various histories and practices of justice of pre-modern peoples are not properly recognized and their idiosyncrasies are lost. They are merely "smoothed over and lumped together" as though they are one form of justice, whereas in reality this is not so. ${ }^{51}$ According to her, it is an error to selectively romanticize the pre-modern past in order to justify a current practice because doing so unwittingly reinforces ethnocentricity, that is, it amounts to a misuse of Indigenous justice practices for the purpose of strengthening restorative justice advocates' positions. Or, as Daly puts it, "the devising of a (white, bureaucratic) justice practice that is flexible and accommodating towards cultural differences does not mean that $[\mathrm{it}]$ is an Indigenous justice practice." ${ }^{\text {} 52}$ Likewise, the commonly-held assumption that some restorative justice practices such as conferencing are directly rooted in Native culture is quite misleading. In the case of

\footnotetext{
${ }^{47}$ Hadley, M. L., "Introduction," in Michael L. Hadley (ed.), The Spiritual Roots of Restorative Justice (Albany: State University of New York Press, 2001) at 9.

${ }^{48} \mathrm{Zehr}, 2002$ at 11.

${ }^{49}$ Daly, K., "Restorative justice: The real story," Punishment and Society vol. 4, no. 1 (2002) at 56.

${ }^{50}$ Ibid. at $62-63$.

${ }^{51}$ Ibid. at 63 .

${ }^{52}$ Ibid.
} 
conferencing, the practice from which it stems was created in the 1980 s by New Zealand's government bureaucrats as a way to better-accommodate the cultural sensitivities of Maori and Polynesian minority groups when engaging them on social welfare and justice matters. Due to the fact that the practice was invented by New Zealand government officials and is therefore not a practice that is taken from Maori and Polynesian cultures, ${ }^{53}$ its origins can hardly predate the arrival of Europeans.

So who is right? I argue both are to some extent. Some inspiration for the development of modern restorative justice comes from ancient and Indigenous practices. If one is inclined to view them as part of the heritage of the restorative justice movement, the claim could be made that restorative justice reaches back into distant past. On the other hand, it is fair to note that there was no systematic consistency or homogeneity among the various practices of vary diverse, geographically separated people. In spite of some similarities, there were significant differences that do not allow them to sit comfortably under one umbrella. It is for this reason that the modern practice of restorative justice does not mimic these historical and Indigenous precedents precisely and, as has already been demonstrated, relies on practices that are of a quite recent genesis. The key point to recognize is that while the current movement might draw upon some practices that predate modern justice for inspiration, it contains important innovations that allow for the necessary nesting within a formal justice system. Also, as Llewellyn and Howse illustrate, the modern theory and practice of restorative justice owes much to the influence of several other modern movements that preceded its

\footnotetext{
${ }^{53}$ Ibid. Also, Donald J. Schmid makes the claim that "no one has been able to cite any concrete evidence that meetings (hui) along the lines of family group conferences were used by Maori prior to European colonization or in the early $20^{\text {th }}$ century," in Restorative Justice in New Zealand: A Model For U.S. Criminal Justice (Wellington: Fulbright New Zealand, 2001) at 12.
} 
emergence. ${ }^{54}$ It is therefore not inaccurate to claim that the modern restorative justice movement is a modern synthesis: it is a new approach to justice that merely draws upon other experiences for ideas and, for the purpose of advocacy and self-justification. ${ }^{55}$

Where does that leave us? I am inclined to agree with the latter assessment, that is, that restorative justice is a new synthesis rather than a conglomeration of pre-modern practices that bear resemblance to one another and have been recently discovered by mainstream justice. Nonetheless, it is worth looking at the origins of restorative justice in both senses because in doing so we have two different means for explicating the motivations that underlie restorative justice. Granted, it may not be possible to trace actual histories vis-à-vis the pre-modern restorative practices because accurate documentation is sparse to absent. Nonetheless, there is enough data present in the literature that seeks to make sense of the ancient practices in order to appreciate the way of thinking behind them. An actual historical sketch is much more probable for the emergence of the modern restorative justice movement.

\section{Pre-modern and Indigenous "restorative" practices}

At the outset, a comment on the lumping together of "ancient" and "Indigenous" is in order. There is a sometimes not-so-subtle tendency to equate the Indigenous with the pre-modern and vice-versa in academic literature, as though Indigenous cultures and societies are static, unchanging and thus crisply preserve the primordial elements of

\footnotetext{
${ }^{54}$ These include the informal justice movement, the "restitution as a response to crime" movement, the victim's rights movement, the reconciliation/conferencing movement, the social justice movement. See Jennifer J. Llewellyn and Robert Howse, Restorative Justice: A Conceptual Framework, (Ottawa: Law Commission of Canada, 1998) at 13-14.

${ }^{55}$ For a concise explanation of how reference to an "ancient" past is used for the justification of restorative justice, see Douglas J. Sylvester, "Myth in Restorative Justice History," Utah Law Review, no. 1 (2003), http://www.law.asu.edu/files/Programs/Sci-Tech/Commentaries/16Sylvester.pdf at 494-495.
} 
humanity's early past. Upon reflection, this is an error. Unfortunately, the literature is replete with examples that do not take into account the dynamism of Indigenous culture and Indigenous groups. Even if they do not equate pre-modern and Indigenous practices outright, many sources tend to address one in terms of the other and unwittingly convey barely hidden assumptions that "Indigenous" means "pre-modern" and vice-versa. In recognizing this error, I adamantly strive to steer clear of it in this section by disentangling the two concepts. In doing so, I describe the restorative justice-related practices of Indigenous cultures. When warranted, I do make references to practices of the past. Likewise, I describe the restorative justice tendencies of early Jewish and Christian traditions.

"Native" justice. Perhaps a good starting point is to describe the blanket set of principles that have been termed the "Native sense of justice" and apparently can be used to characterize the conceptualization of justice of all non-European Indigenous groups. It is held that Native social order, unlike modern state-based social order, rests on a "balance between and among kin groups." For that reason whether an action is deemed to be a wrong depends on whether it disrupted the balance between the kin groups." ${ }^{\circ 7}$ Rectifying the wrong in the Native justice context, for instance in the case of a murder, could require a transfer of wealth from the kin group of the offender to the offended kin group or the killing of a member of the former, but not necessarily the offender. ${ }^{58}$ In this respect, Native justice has quite a different frame of reference from that of state-based justice,

\footnotetext{
${ }^{56}$ Samuel C. D., "Restorative Justice: Prison and the Native Sense of Justice," Journal of Legal Pluralism, no. $47(2002)$ at 83 to 111 .

${ }^{57}$ Ibid. at 85 .

${ }^{58}$ Ibid. at 92.
} 
which places its primacy on the rule of law. ${ }^{59}$ It is perhaps, in part, from this that the modern restorative justice practice derives its emphasis on restoring the relationship between the offender and the community.

In addition to the different frame of reference, Native justice does not have a role for the sort of centralized legal authority that characterizes modern state-based justice. ${ }^{60}$ In the state-based system the state is the ultimate authority that defines individuals as subjects of the law. Native justice on the other hand sets the primacy of the kin group above that of the individual or the state. ${ }^{61}$ That is, justice entails mending the social fabric within and between kin groups which is damaged during the commission of a wrong. This purported characteristic of traditional Native justice constitutes an interesting hurdle for the expansion of modern restorative justice to the extent that it needs to reorient itself away from its "original" focus on the kin group and become a practice that "re-affirms the individual's status as a subject of the law." modern practice of restorative justice is contingent on the consent of the state, ${ }^{63}$ it will be worth exploring further on how the emphasis on kin groups has been displaced by (or transformed into) other notions of "primary victims" (that is, the ones most directly impacted by the offence ${ }^{64}$ ), "secondary victims" (that is, the others impacted by the

\footnotetext{
${ }^{59}$ Ibid. at 91 .

${ }^{60}$ Ibid. at 96.

${ }^{61}$ Ibid. at 105 .

${ }^{62}$ Ibid.

${ }^{63}$ Bazemore, G., "Crime Victims and Restorative Justice in Juvenile Courts: Judges as Obstacles or Leader," Western Criminology Review, vol. 1, no. 1 (1998), http//wcr.sonoma.edu/vlnl/bazemore.html.

${ }^{64}$ Zehr, H., and Mika, H., "Fundamental Concepts of Restorative Justice," in Restorative Justice On-Line Notebook (U.S. Department of Justice, 1997), http://www.ojp.usdoj.gov/nij/rest-just/ch1/fundamental.html.
} 
crime $^{65}$ ), such as "family members", "friends", "criminal justice officials", "community"

Specific North American Native roots. Native North American ceremonies are considered to have a role in shaping the modern conduct of restorative justice. The Healing Circle, the Sweat Lodge, the Vision Quest and the Pipe Ceremony are some of the main examples of important spiritual ceremonies of different North American Native groups. ${ }^{67}$ However, Paul Skanks, Traditional Mohawk Nation Teacher, highlights the need to understand the true meaning of ceremonies. According to him:

Ceremony could mean many things. When we talk of ceremony as a practice or as an understanding that gives some insight beyond just our every day ordinary way of doing things, it connects us in a spiritual way our heritage, ancestry, the true meaning of medicines and all of them [ceremonies] begin with an inner focus of self. Sometimes what am I missing, where am I going and all of these kinds of questions have different levels of understanding. It begins with self, who I am and what am I looking for? What is it I believe in? And at the end there is this restoration, a recovering of self... ${ }^{68}$

Further, the purpose of these ceremonies is to "retrace the track, regain the lost, and recreate community." ${ }^{69}$ They serve to restore the self-respect of individuals, create an awareness of their roots, generate a sense of mutual connectedness, nurture the spirit and strengthen the community by reinforcing the place and responsibilities of individuals in the community. ${ }^{70}$

\footnotetext{
${ }^{65}$ Restorative Justice: A Framework for Fresno (Fresno: February, 2001), http://peace.fresno.edu/docs/rjframe0201.pdf. ${ }^{66}$ Ibid.

${ }^{67}$ Blue, W. A. and Blue, R. M. A., "The Case for Aboriginal Justice and Healing: The Self Perceived through a Broken Mirror," in The Spiritual Roots of Restorative Justice (Albany: State University of New York Press, 2001) at 69.

${ }^{68}$ Interview with Skanks, E. P., September 12, 2006.

${ }^{69}$ Blue, W. A. and Blue, R. M. A. at 69.

${ }^{70} \mathrm{Ibid}$
} 
Of the ceremonies mentioned above, perhaps the one to have figured most prominently in the genesis and evolution of the modern practice of restorative justice is the healing circle. According to Jane Dickson-Gilmore and Carol La Prairie, "the circle has important and profound cultural significance." $" 71$ Further the authors elaborate on the significance of the circle by saying that it is "[s]ymbolizing the interconnectedness of all things and directing consideration of the impact on all partners in that symbiosis when decisions are taken, the concept of the circle is synonymous with balance, openness, and a holistic approach to life." 72 It has been adapted to suit restorative justice and its modern form is better-known as the sentencing circle. The main motivation that underpins both the modern ceremony and the traditional one from which it was adapted is the restoration of the disrupted harmony of the group. ${ }^{73}$ The circle is important to restorative justice because it constitutes one of its main practices. This Native tradition thereby gives the modern restorative justice movement both form and substance (if you consider the underlying motivations of circles). The modern variant of the ceremony is attended by a group of people from the community who sit in a circle. ${ }^{74}$ The ceremony is led by an Elder, who starts things off with a prayer" and "speaking a few words usually of thankfulness and understanding of how things are." ${ }^{\text {76 }}$ Following that, the Elder passes a sacred object (usually "eagle feather," "talking stick," or "talking stone,"77) around the circle. As it goes around, each individual may say anything he/she wishes while holding

\footnotetext{
${ }^{71}$ Dickson-Gilmore, J., and La Prairie, C., Will the Circle be Unbroken? Aboriginal Communities, Restorative Justice, and the Challenges of Conflict and Change (University of Toronto Press, 2005) at vii. ${ }^{72}$ Ibid.

${ }^{73}$ Blue and Blue at 76.

${ }^{74}$ Ibid.

${ }^{75}$ Ibid.

${ }^{76}$ Ibid.

${ }^{77}$ Waldram, B. J., The Way of the Pipe: Aboriginal Spirituality and Symbolic Healing in Canadian Prisons (Broadview Press, 1997) at 135.
} 
on to the object. ${ }^{78}$ The circle provides every participant a means to speak "from the heart in a shared search for understanding" of the offence and to mutually identify the steps that are needed for the healing of all affected persons. ${ }^{79}$ In this way, the circle functions to restore the previously-disrupted harmony of the group. ${ }^{80}$ Blue and Blue add that the discursive nature is "the underlying variable in the success of the sentencing circle, which contributes to the rebuilding of the harmony within the community." ${ }^{\prime 81}$ Thus, discursiveness that occurs during the time of the sentencing circle may be the direct result of interrelatedness between the offenders, victims and community members, which, according to Blue and Blue "is the essential positive ingredient that rebuilds the community cohesiveness necessary for healing to take place." ${ }^{\prime 82}$ Further, "defining crime is the people's way of saying that there is something very wrong with the society, and the sentencing circle may be the people's way of dealing with the wrong." ${ }^{.83}$ Therefore, according to Hudson, "discursiveness is a key feature or restorative justice," where "all parties (offenders, victims, community representatives) are allowed to tell their stories in their own words." 84

The valid question to ask here would be how does speaking restore harmony?

Skanks, Traditional Mohawk Nation Teacher, tackles the question above. He says that I could be very articulate, nice words that would empress you, but it is not the speaking alone that restores the balance. It's the acting, it's the carrying out. We have an expression, it's a word and I teasingly do this sometimes to students. I say 'Kana ronkwa' and they get all embarrassed, and say oh you are so silly. It

\footnotetext{
${ }^{78}$ Ibid.

${ }^{79}$ Zehr and Mika, "Sentencing Circles," in Restorative Justice On-Line Notebook (U.S. Department of Justice), 1997, http://www.ojp.usdoj.gov/nij/rest-just/CH5/3_sntcir.htm.

${ }^{80}$ Blue and Blue at 76.

81 Ibid.

82 Ibid.

${ }^{83}$ Ibid.

${ }^{84}$ Hudson, B., "Beyond White Man's Justice: Race, Gender and Justice in Later Modernity," (Theoretical Criminology, University of Central Lancashire, SAGE Publications, London, 2006) at 6-7.
} 
means 'I love you'. But see, it doesn't talk about physical love or romantic love, it means I care about you. I care enough about you to be there if I'm needed. I care enough about you to listen if that is all that is needed. I care enough about you that if there is something that you need that I have that I will share it with you. Or I do something to help you or your family, particularly if I perpetrated something. ${ }^{85}$

Skanks reiterates that "it is not just speaking that restores the harmony" and elaborates by saying that "for an offender to join the circle in the first place, to come voluntarily speaks very loudly." 86 It means that "now, amongst my peers, amongst my community and everyone else, I am laying myself open to have them tell me how my actions have impacted them." 87 According to Skanks, "the fundamental understanding of responsibility for wrongful actions - this is how the healing, the restoration begins; this is the first step. ${ }^{\prime 88}$

Specific Maori roots. Modern restorative justice also has roots in pre-European Maori justice traditions. These were supplanted by European traditions upon their arrival. However, prior to the Europeans, the Maori indeed had a system of justice that had a highly developed oratory, but no codified laws, courts, judges, etc. ${ }^{89}$ It had both a spiritual dimension and a material dimension. ${ }^{90}$ Compensation for minor crimes was determined by the community. Elders and chiefs decided compensation for major offences. ${ }^{91}$ Typically, punishment consisted of a transfer of goods to the victim unless the crime was part of a pattern of persistent theft, or murder. In those cases, sanctions

\footnotetext{
${ }^{85}$ Interview with Paul E. Skanks. Ottawa, ON, September 12, 2006.

${ }^{86}$ Ibid.

87 Ibid.

88 Ibid.

${ }^{89}$ Case Study 1: "Maori of Aotearoa (New Zealand)," in Sustainable Social Relationships UNESCO, http://www.unesco.org/education/tlsf/theme_c/mod11/uncom1 1 t03s04.htm\#top.

${ }^{90}$ Ibid.

${ }^{91}$ Ibid.
} 
included plunder, beating, withdrawal of community support, or banishment. ${ }^{92}$ Respect for the spirit world was fundamental to this system. ${ }^{93}$

Judeo-Christian roots. Restorative justice is rooted, in part, in early Jewish and Christian beliefs. The most general example, perhaps, is that Rabbinic law aims ultimately to "achieve a harmony among persons and with God."94 This emphasis on creating harmony as a motive behind the idea of justice no doubt resonates with the modern restorative justice movement. So does the ancient, fundamental Jewish belief in the possibility of repentance and breaking free from the cycle of past wrongs by turning over a new leaf. ${ }^{95}$ What is particularly relevant to the modern understanding of restorative justice is how this belief is ideally put into practice. Full repentance involves confession, expressions of remorse and a resolve to change one's ways in the future. ${ }^{96}$ There is clearly a community-oriented dimension to these aspects of traditional Jewish practice. For example, a reformed sinner is to be treated with compassion by all individuals of his/her respective community, including those that had been wronged. ${ }^{97}$ Furthermore, even the Jewish conceptualization of repentance transcends the individual, as the Jewish faith regards individual repentance as just one part of the larger goal of collective repentance. ${ }^{98}$ This perspective is no doubt related to the Jewish concept of peace, known as Shalom, which means much more than an absence of conflict in that it consists of

\footnotetext{
92 Ibid.

${ }^{93}$ Ibid.

${ }^{94}$ Segal, E., "Jewish Perspectives on Restorative Justice," in The Spiritual Roots of Restorative Justice (Albany: State University of New York Press, 2001) at 183.

${ }^{95}$ Ibid.

${ }^{96}$ Ibid.

97 Ibid.

${ }^{98}$ Frankel, E., "Repentance, Psychotherapy and Healing Through a Jewish Lens," American Behavioral Scientist vol. 41, no. 6 (March 1998) at 815 .
} 
"completeness, fulfillment, wholeness - the existence of the right relationships among individuals, the community and God." 99 It too stresses interconnectedness between the individual and the community.

Restorative justice bears resemblance to ancient Jewish tradition in other ways as well. With respect to crimes pertaining to theft or destruction of property, biblical law requires restoration of the item in question or its equivalent value, to the extent that repayment does not impede the rehabilitation of the criminal. ${ }^{100}$ In fact, there is a strong dynamic favouring rehabilitation in the Hebrew Scriptures. ${ }^{101}$ There is also a strong notion of personal atonement. ${ }^{102}$ These underlying motivations clearly resonate in the modern practice of restorative justice in that it too emphasizes personal accountability for harm and righting the wrongs (discussed further in Chapter 3).

The principles of early Christianity are likewise seen as one of the deep-rooted elements of restorative justice. Perhaps most notable is the "revolutionary ethic of forgiveness" introduced by Jesus in the Sermon on the Mount. ${ }^{103}$ It was revolutionary because it demanded love of our enemies and those who are unjust. ${ }^{104}$ This forgiveness is the "most significant process for overcoming the devastation of crime" and it is an important element in the repair of disrupted human relations. ${ }^{105}$ The early Church invited its members to receive offenders with joy and compassion, encourage them by showing

\footnotetext{
${ }^{99}$ Bazemore, "Restorative Justice and Earned Redemption: Communities, Victims, and Offender Reintegration," American Behavioral Scientist vol. 41, no. 6 (March 1998) at 773.

${ }^{100}$ Segal, 2001 at 185-186.

101 Allard, P., and Northey, W., "Christianity: the Rediscovery of Restorative Justice," in The Spiritual Roots of Restorative Justice (Albany: State University of New York Press, 2001), at 133.

${ }^{102}$ Segal at 186.

${ }^{103}$ Allard and Northey, at 120.

104 Ibid.

${ }^{105}$ Ibid. at 121 .
} 
them mercy and giving them hope, and leading them to repentance. ${ }^{106}$ Early Christian thought was consistent with the above-mentioned Hebrew notion of Shalom, which carries a meaning of salvation, justice and peace. ${ }^{107}$ There are a great number of New Testament passages that convey a message of "restoration, reconciliation and peaceful communities." 108 Clearly the early Christian tradition and the modern restorative justice movement share some key underlying motivations.

However, I would like to question the true validity of Christianity's deep rooted values of forgiveness, restoration, compassion and mercy as they were put into practice in early modern Europe, "which covers the period roughly from 1500-1800."109 Looking closer into the history of prisons, where churches (of various denominations) played a significant role, ${ }^{110}$ it becomes evident that church officials were not always as forgiving, merciful or restorative as it is demonstrated. For example, in early modern Europe "torture was a tool for questioning prisoners and so qualified as part of the fact-finding process." "Some church officials "had the authority to pronounce death sentences, even though it was only done in minority of cases." "12 Also, shaming, referred as public penance, obliged "the offender to go barefoot while dressed in the sheet." also did not show signs of compassion and punished women severely when "accused of immoral conduct had to wear an outfit or carry a symbol [in public] that marked their

\footnotetext{
106 Ibid.

107 Ibid.

108 Ibid. at 135.

${ }^{109}$ Howard, S., Early Modern Resources. http://www.earlymodernweb.org.uk/emr/.

${ }^{110}$ Spierenburg, P., "The Body and the State," in Mooris, N. and Rothman, J. D., The Ox ford History of the Prison: The Practice of Punishment in Western Sociey, (Oxford University Press, 1995) at 45.

III Ibid.

${ }^{112}$ Ibid. at 46.

${ }^{113}$ Ibid. at 47.
} 
degradation." 114 And punishments as whipping, burning the convicts' skin, mutilation just to name a few were the penalties administered in early modern Europe. ${ }^{115}$

Much has evolved since then; however, we should not fall into the trap of romanticizing the role of Christian churches of that era and their role in the contemporary penal systems.

\section{History of the modern restorative justice movement in Canada}

Victim-offender reconciliation project. The history of the modern restorative justice movement has its beginnings in Canada. It is generally held that the movement began in 1974 with the first case of the victim-offender reconciliation program was applied in Kitchener, Ontario. ${ }^{116}$ The idea quickly took root and spread to the United States. ${ }^{117}$

This first instance of modern restorative justice was applied to two offenders charged with vandalism and consisted of meetings with victims to establish restitution agreements. ${ }^{118}$ The case was brought before a young parole officer, Mark Yantzi, who, along with volunteers, was brainstorming ahead of working on pre-sentencing reports. Yantzi mused that it may be worthwhile to have the youths meet their victims in order to work out means to compensate them for their losses. ${ }^{119}$ Because nothing like this had

\footnotetext{
114 Ibid.

${ }^{115}$ Ibid. at $46-48$

${ }^{116}$ See Jeff Latimer and Steven Kleinknecht, The Effects of Restorative Justice Programming: A Review of the Empirical (Ottawa: Department of Justice Canada, 2000) at 5; Susan M. Olson and Albert W. Dzur, "Revisiting Informal Justice: Restorative Justice and Democratic Professionalism," Law and Society vol. 38, no 1 (2004) at 143; Nawal H. Ammar, "Restorative Justice in Islam: Theory and Practice," in The Spiritual Roots of Restorative Justice (Albany: State University of New York Press, 2001) at 162; and Mark S. Umbreit, Robert B. Coates and Betty Vos, "Restorative Justice versus Community Justice: Clarifying a Muddle or Generating Confusion?", Contemporary Justice Review vol. 7, no. 1 (March 2004) at 83 .

${ }^{117}$ Huculak and McWhinnie, "Restorative Justice Innovations in Canada," Behavioral Sciences and the Law vol. 20 (2002) at 364.

${ }^{118}$ Latimer and Kleinknecht at 5.

${ }^{119}$ Ibid.
} 
been attempted before, Yantzi did not think it could be done. However, the volunteers encouraged him to pursue the idea regardless and so he approached the offenders with it. They appeared cautiously agreeable, acknowledging that it would be fair but tough. ${ }^{120}$ In completing the pre-sentence report, Yantzi added a one-page appendix outlining the possibility of a meeting with victims and some form of restitution. The judge who presided over the case just happened to be weary of repeat offenders and was open to considering new approaches. For that reason, he took up the idea and ordered the coaccused to meet their victims, determine the cost of the damage and pay them for anything not covered by insurance. ${ }^{121}$ In this way, the first victim-offender reconciliation project was born. While Yantzi's motivations for the original idea are not explicit, they are implicit in the name that he chose for the project. Obviously, he sought to reconcile the victim and the offender. It is also true that Yantzi had come to see the mainstream justice system's reliance on punishment as ineffective. ${ }^{122}$

Although the term "restorative justice" had not yet been coined, the victimoffender reconciliation project effectively laid the foundation for the movement. Yantzi wrote up the case in a report to the Mennonite Central Committee, where it generated much excitement. ${ }^{123}$ In addition, the media picked up on the case and there was a stream of magazine and newspaper articles on the initiative. However, the surest measure of success was when judges in Kitchener began to refer additional cases to Yantzi and his

\footnotetext{
120 Ibid.

121 Ibid.

122 Ibid.

123 Ibid.
} 
group. The idea continued to spread and by the early 1990s, there were two dozen victim-offender reconciliation projects in Ontario. ${ }^{124}$

The idea spread beyond Canada. In 1977, Howard Zehr, the director of the criminal justice office of the American Mennonite Central Committee, adapted the idea in creating the first victim-offender mediation program in the United States. ${ }^{125}$ Variants of these programs spread across the United States, usually initiated by faith communities attempting to facilitate face-to-face engagement between victims and offenders. ${ }^{126}$ By the 1980 s, similar projects emerged in New Zealand, Australia and Europe. ${ }^{127}$

Sentencing Circle. A prominent form that restorative justice eventually took was that of the Sentencing Circle. The first of these appeared in the Yukon Territory and the Province of Saskatchewan in $1992 .{ }^{128}$ The process brings together the offender, supporters, Elders, judges and victims in order to deal with the underlying causes of the criminal behaviour. ${ }^{129}$ The process was designed to combine respect for due process, mediation/negotiation, consensus-based decision making and aboriginal healing and peacekeeping concepts. ${ }^{130}$ It should be noted, however, that even though this model draws upon Indigenous traditions, it is not "inherently "aboriginal" "itself, ${ }^{131}$ in that it was conceived of by the justice system and from the start was a hybrid of justice system priorities and Indigenous traditions. While the model has proliferated in Canada since its

\footnotetext{
124 Ibid.

125 Ibid.

126 Transforming Relationships Through Participatory Justice, (Ottawa: Law Commission of Canada, 2003) at 36.

${ }^{127}$ Butler, D., "Restorative justice processes fall into three broad categories, though increasingly they are being blended," Ottawa Citizen, September 11, 2004 at A1.

${ }_{128}$ Wilson et al at 364.

${ }^{129}$ Butler, D., at B2.

${ }^{130}$ Wilson et al at 364

${ }^{131}$ Ibid.
} 
inception, its informal structure has created some problems for its implementation in different locales. ${ }^{132}$

Conferencing. Another prominent form that restorative justice took was that of conferencing. It drew upon the practice of "family group conferencing," which was created in 1989 in New Zealand through the enactment of a new law (Children, Young Persons and Their Families Act of 1989) that dealt with "care and protection for children and with youth crime. ${ }^{.133}$ The motivations behind the new practice and the bill that created it was to involve parents, family groups, kin groups and the tribal community in developing solutions to problems and to attend to the cultural sensitivities of the Indigenous population. ${ }^{134}$

The process of a family group conference can be summarized as follows. ${ }^{135} \mathrm{~A}$ youth justice coordinator calls on the victim to meet with the offender and the offender's family. Police are present at the conference. The conference begins with the police reading a "statement of the facts," which describes the offence and background information about the youth offender. If the offender agrees to the facts of the offence the victim is then asked to speak about the impact the offence. On those occasions when the victim is unable or unwilling to participate in person, the youth justice coordinator may read a statement from the victim relating the impact of the offence on him/her. Most often, this is followed by an apology or some expression of remorse by the offender. After that, the conference participants engage in collective discussion about what should

\footnotetext{
132 Ibid.

${ }^{133}$ Schmid, D. J., Restorative Justice in New Zealand: A Model for U.S. Criminal Justice (Wellington: Fulbright New Zealand, 2001) at 12.

${ }^{134}$ Ibid. at 11-12.

${ }^{135}$ This description is provided by Schmid at 13 .
} 
be done to repair the harm to the victim (including payment of restitution) and what the offender should do in order to be held accountable for the offence. Following the discussion, the offender is left alone with his/her family to discuss a suitable plan. The entire group then reconvenes to hear of the proposed family group conference plan from the family and the offender. The plan is discussed and negotiated by the parties, including the police and the victim. If an agreement is attained, the plan is recorded by the justice coordinator. If criminal charges had been presented in court, the family group conference plan is presented to the court for approval.

A spin-off of this model was developed in 1991 in Wagga Wagga, Australia as a community policing technique. ${ }^{136}$ The format is basically the same, only this type of conference ends in a social gathering (with refreshments) during which the offender is symbolically "reintegrated." 137 This same format was adopted in Canada, in 1999 by the RCMP (who consulted extensively with Wagga Wagga practioners) for use in youth crime. $^{138}$ The first session was held in August 1999 by Victoria Parole staff who had been trained in the practice by the Westshore RCMP detachment. ${ }^{139}$

Other influences. There are several intersecting factors and influences that served as a further impetus to restorative justice. First and foremost of these is the deep dissatisfaction with the conventional justice system in the developed world that resulted from the apparent failure of the central institutions of the criminal justice system. ${ }^{140}$ The

\footnotetext{
${ }^{136}$ Butler, "Restorative Justice Practices" at B2.

${ }^{137}$ Ibid.

${ }^{138}$ Wilson et al at 372.

${ }^{139}$ Ibid.

${ }^{140}$ Cohen, L. R., "Provocations of Restorative Justice," Social Justice Research, vol. 14, no. 2 (June 2001) at 209.
} 
system was failing in its main mission of public safety and rehabilitation: the public felt less safe and recidivism was growing. ${ }^{141}$ In all of this, victims often felt that they did not have a voice, that is, even though they were directly affected by the crime, they were virtually shut out of the administration of justice; they were sidelined. The dissatisfaction was matched perhaps only by the frustration that, try as it may, conventional justice was not about to break free of this spiral and improve the situation.

In addition to the perceived failure of the conventional system, restorative justice received a push from several complementary movements that also sought to make an impact on criminal justice. Prominent among these are the victims' movements. There was a proliferation of victims' groups (victims' rights, victim advocacy groups and victim support programs) more or less at the same time that restorative justice had started to gain ground. ${ }^{142}$ These groups worked to shed light on the fact that victims were sidelined by the prosecutorial system, where the state stands in for the victims, effectively excluding them from the process. ${ }^{143}$ Previous assumptions about the congruency of the interests of the state and those of victims were proven false as victims were often left wanting vis-à-vis procedural matters and, of course, information concerning their particular experience. ${ }^{144}$ Naturally, many victims' groups embraced restorative justice to the extent that it gave victims much-needed voice. ${ }^{145}$ Also pertinent to restorative justice is the fact that victims' groups have made certain inroads, for example the practice of victim impact statements and the victims' bills of rights in Manitoba and Ontario. ${ }^{146}$ This

\footnotetext{
${ }^{141}$ Ibid. at 210.

${ }^{142}$ Transforming Relationships Through Participatory Justice (Ottawa: Law Commission of Canada, 2003) at 19 .

${ }^{143}$ Ibid. at 20.

144 Ibid.

145 Ibid.

${ }^{146}$ Ibid. at 23-24.
} 
growth in support for victims in the mainstream is a current that has done much to propel restorative justice in that it has helped create a perception that victims have needs as well as a rightful role in the administration of justice. However, the issue of whether such a perception should be contested is not without debate. Though perhaps it may be a debate for another place, I will nonetheless acknowledge that there are strong arguments for the limitation of victim influence over criminal adjudication, based primarily on the principle that sentencing should be contingent on the objective blameworthiness of the offender and the seriousness of his/her offence and not the whims of victims. ${ }^{147}$

\section{Origins of prison chaplains}

The origin of prison chaplaincy lies in the emergence of institutional prisons. The two have gone hand-in-hand right from the start. One of the earliest documented developments of key importance in respect to the formal institutional development of the role of prison chaplains dates back to the Victorian era. In early modern Europe the church courts "handled all kinds of matters in the realm of marriage and sexuality" "48 and later the church teachings expanded to the prisons. A role was prescribed for chaplains in the prison reforms (reforms "meant religious conversion"149) promulgated by Jonas Hanway and later by John Howard who gave chaplains a central role in prisons.

"Suffering was no longer physical pain exploited in a drama intended for an audience but was a spiritual ordeal provoked for the prisoner's own good." ${ }^{150}$ This role included

\footnotetext{
${ }^{147}$ Robinson, H. P., "Should the Victims' Rights Movement Have Influence Over Criminal Law Formulation and Adjudication?" McGeorge Law Review, vol. 33, no. 4 (summer, 2002) at 749. http://1sr.nellco.org/cgi/viewcontent.cgi?article=1040\&context=upenn/wps

${ }_{148}$ Morris, N. and Rothman, J. D., The Ox ford History of the Prisons: the Practice of Punishment in

Western Society, (Oxford University Press, 1998) at 45.

${ }_{149}$ Morris and Rothman at 77.

${ }^{150}$ Ibid. at 77.
} 
religious services, welfare and pastoral duties. ${ }^{151}$ In fact, prisons of the era "were designed to have religion within their core." 152 As of 1823, chaplains in British prisons "were required to visit cells and to keep written records of their visits." 153 A ministry comparable to modern prison chaplaincy had most definitely emerged. The motivation behind the chaplaincy aspects of Howard's prison reforms stems from his visits to numerous European prisons where he witnessed the reformative potential of ministering to inmates. ${ }^{154}$

Fortunately, for my purposes, I need not dwell much further on the history of British prison chaplaincy. I am, after all, interested in Canadian prisons. Nonetheless, the discussion of the origins of prison chaplaincy in Britain is relevant given that these developments in Britain did affect the nature of emergent prisons in Canada. It is to the discussion of the history of prison chaplains in Canada that I now turn.

\section{History of prison chaplains in Canada}

Prison chaplaincy in Canada has its origins in Britain. As alluded to previously, prison chaplaincy emerged in Britain just decades before Kingston Penitentiary was built. ${ }^{155}$ Because the religion of the establishment in Canada was the Church of England, the first chaplains in the Kingston Penitentiary were British-trained Anglican clergymen. ${ }^{156}$ They transplanted the British model of prison chaplaincy to Canada. The first chaplains were

\footnotetext{
${ }^{151}$ Beckford, A. J., and Gilliat, S., Religion in Prison: Equal Rites in a Multi-Faith Society (Cambridge: Cambridge University Press, 1998) at 26.

${ }^{152}$ Ibid.

${ }^{153}$ Ibid. at 26-27.

154 James, C.T., A Living Tradition: Penitentiary Chaplaincy, (Ottawa: Correctional Services of Canada, 1990 ) at 61.

${ }^{155}$ Ibid. at 59 .

${ }^{156}$ Ibid. at 60.
} 
integrated into the overall work of the prison and in this way were an important part of the institution. ${ }^{157}$

From the start, Canadian prison chaplains were required to write annual reports, a practice that originated in Britain. ${ }^{158}$ These reports went to various inspectors and commissioners and through them to the federal Minister of Justice. They were published until 1916. ${ }^{159}$ This practice accorded Canadian prison chaplains with a means to express concerns and advocate reform. ${ }^{160}$ A particularly notable example is that of Fr. Joseph Leclerc, who commenced his ministry in 1873. Leclerc wrote particularly lengthy, detailed reports, which over time took on the form of powerful discourses on penology. ${ }^{161}$ As one would suspect, these annual reports contain numerous insights into the individual motivations of the prison chaplains. A recurrent theme is the sense of humility and gratification that the chaplains experienced in doing God's work. ${ }^{162}$ So too is their evident desire to reform inmates by instilling them with "good principles" and "good emotions and habits" that "render their temporary detention in the institution a permanent blessing to them."163 Rev. George Schofield wrote in 1875 that he felt "it to be a very serious responsibility to attempt the reform and salvation of these men."164 He saw it as his duty to "care for these men, and if possible to train them to become good citizens and good Christians." 165 He perceived his ministry to have been successful because "in many hearts convictions of sin have been produced, holy resolutions have been cherished and

\footnotetext{
157 Ibid.

158 Ibid. at 65.

${ }^{159}$ Ibid.

160 Ibid.

${ }^{161}$ Ibid. at 65-66.

${ }^{162}$ Ibid. at 66-67.

${ }^{163}$ Ibid. at 67.

164 Ibid.

165 Ibid.
} 
aspirations after a purer and more religious life have been fostered."166 His words are consistent with those of Fr. Antoine Ouellet who in 1877 wrote that "it proves great consolation for a pastor of souls when he sees that the Lord blesses his humble efforts in rescuing sinners from the abyss of perdition."167 Likewise, Rev. A. W. Cooke commented in his report of 1906 on the inspiration received from the thanks received from those who benefited from the various aspects of his ministry and have become "disposed to think seriously of life and its responsibilities."

Some of the reports of early Canadian prison chaplains resemble what we know today as "mission statements." "The The are particularly revealing of the motives behind their individual ministries. For instance, Fr. Emile Pascal wrote in 1912 of his mission

To bring these poor inmates nearer to God, by the observance of the divine commandments and submission to the rules of our dear country, in a word, striving to alleviate the misery of man, and to lighten the burden of his infirmities, whether this misery and these infirmities are hereditary or whether they are the result of his own wrongdoing, such is my ambition as a minister of the gospel. ${ }^{170}$

More pointedly, in 1916 he wrote of his goal of "instilling into the minds of these unfortunates the necessity of not remaining buried in this deplorable condition, but to prepare to enter, upon their release, a useful and honourable life."

Early Canadian prison chaplains were also among the early penal reformers in this country. It is they that first observed that the rehabilitative efforts of prisons often were applied too late and they therefore recommended reforms at the community policing level. ${ }^{172}$ They also were cognizant of the fact that long prison sentences often had the

\footnotetext{
${ }^{166}$ Ibid. at 68 .

${ }^{167}$ Ibid.

${ }^{168}$ Ibid. at 71.

${ }^{169}$ Ibid.

170 Ibid.

${ }^{171}$ Ibid. at 72 .

${ }^{172}$ Ibid at 76.
} 
reverse reformatory effect. ${ }^{173}$ Some prison chaplains were concerned for the fate of prisoners after their release and successfully advocated retaining earnings to be paid out upon release. ${ }^{174}$ Others understood the importance for prisoners to maintain contact with the outside world and helped the illiterate write letters, often bringing upon themselves the chastisement of prison authorities. ${ }^{175}$

It is only fair to note that even with the work of prison chaplains, prisons remained brutal places. It is not clear to what extent prison chaplains succeeded in mitigating this brutality. Also, because prison chaplains served two masters (their respective church/faith group and the Correctional Service), ${ }^{176}$ in some cases they were co-opted by the institution to serve its ends, ${ }^{177}$ sometimes at the detriment of their intended pastoral commission. For example, a letter to the Commissioner of the Provincial Penitentiary from the Secretary to the Lieutenant Governor (November 26, 1847) provides an example of co-option and "the linkage between the chaplain and institutional discipline. $" 178$ It states:

"in cases when prisoners are refractory or indolent, His Excellency considers that it would not only be just to the others but really salutary to the offenders themselves that they should be confined in solitude with the reduced diet of bread and water, and he thinks that if the discipline were carried out with strictness and followed up by timely admonition from the chaplain, that the most hardened of them might be brought to some sense of their misconduct and the seeds of reformation be thus sown."179

Nonetheless, what is important for the purposes of this thesis is the underlying set of motivations that guided the intended work of chaplains historically and shaped its

\footnotetext{
${ }^{173}$ Ibid.

${ }^{174}$ Ibid.

${ }^{175}$ Ibid. at 77 .

${ }^{176}$ Ibid. at 107 .

${ }^{177}$ Ibid. at $84-85$

${ }^{178}$ Ibid.

${ }^{179}$ Ibid.
} 
evolution over time. Many of these underlying motivations are analogous to those that underpin the historical roots of restorative justice.

\section{Prison chaplains today}

The above discussion elucidates the motivations that guided prison chaplains as the ministry emerged in Canada and during its early days. Naturally, the thinking has been augmented over time. In addition to the motives stated above, many of which come from interpretations and understandings of sacred literature and sacred tradition, prison chaplaincy today must be guided by several sources, including the Canadian Charter of

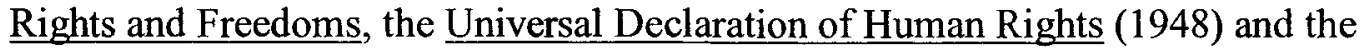
Canadian Human Rights Act (1977), the Corrections and Conditional Release Act (1992), the United Nations Standard Minimum Rules for the Treatment of Offenders (1955), and the (2000) Memorandum of Understanding between the Correctional Service of Canada and the Interfaith Committee. ${ }^{180}$ These documents present for prison chaplains (as well as other prison employees) a set of principles primarily concerning the human rights of inmates and, in some cases, Canadian legal norms that prison chaplains must adhere to when ministering to the prison community.

Canada's cultural composition has changed markedly over the past one hundred years and is now colloquially likened to a mosaic. In spite of the fact that this diversity of culture and faith tradition is reflected by the Canadian prison population, the prison chaplaincy system remains dominated by chaplains of Christian traditions, both in terms of their numbers and administrative positions (chaplaincy coordinators). That is not to

\footnotetext{
${ }^{180}$ National Chaplaincy Evaluation: Pastoral Care (Ottawa: Correctional Services of Canada, 2004) http://www.csc-scc.gc.ca/text/prgrm/chap/pastoral_care_report_e.shtml.
} 
say that they bar access to ministers of other faith traditions - far from it. They are in fact mandated to provide access to ministers of other faiths, as requested by prisoners. Nonetheless, Christian chaplains are often the de facto gate keepers of the chaplaincy system, as they were in the early days of the Canadian prison system.

\section{Historical confluence of motivations?}

It is apparent when the general histories of prison chaplaincy and restorative justice are compared that there is a significant commonality between the motivations that underpin the emergence and development of each. Most striking is the spiritual imperative. Both restorative justice, with its roots in various faith traditions, and prison chaplaincy emerge from a genuine concern for the spiritual well-being of offenders and other affected persons. Pastoral care figures in the history of each, even if its presence today is more explicit in the current mandate of prison chaplains.

Concern for material well-being is also characteristic of the origins of both restorative justice and prison chaplaincy. While restorative justice focuses on the victim more so than does prison chaplaincy, it also attends to the material well-being of the offender, as demonstrated in the discussion on the influence of Judaism in restorative justice.

Restoration of the offender to society is likewise a goal rooted both in the origins of restorative justice and prison chaplaincy. Perhaps restorative justice has been more explicit in this regard by identifying the community as one of the affected parties and its members as participants in its various different practices. However, prison chaplaincy too has shown concern in this regard by specifically helping inmates prepare for re-entry 
into society. In addition to working to reform the offender so that he/she may re-enter society better aware of his/her responsibilities and as a good citizen, prison chaplains have historically tried to facilitate some communication between the prisoner and the outside. How they have come to do so in the present will be discussed in Chapter 4 . While both restorative justice and prison chaplaincy have adapted in different ways to the prevailing justice system, both are motivated by a notion of an alternate path. Restorative justice quite explicitly offers an alternative to conventional justice. Prison chaplaincy, though nested in an institution of the conventional justice system, also traditionally offers inmates means to transcend their sentence.

Finally, both restorative justice (in its modern sense) and prison chaplaincy have shared many notions of the need for institutional reform. Most notably, both have been critical of the detriment of long periods of incarceration.

In sum, the histories of restorative justice and prison chaplaincy reveal a commonality of motivations that underpin both movements. 


\section{Chapter 3: Overview of Restorative Justice Theory}

This chapter provides an overview of restorative justice theory and offers a theoretical guide against which the restorative role of prison chaplains can be better understood. I am interested in the coincidental restorative function of prison chaplains, that is, through their typical work in a corrections environment, apart from any formal restorative justice programme. I am also interested in the aspects of this natural complement as they pertain to the participation of prison chaplains in formal restorative justice programmes. For this reason, I bear both circumstances in mind as I distil the key elements of restorative justice, my purpose being to produce a broad theoretical framework against which the restorative role of prison chaplains can be assessed, both in terms of their natural pastoral activities, as well as their efficacy as participants in formal (court sanctioned) restorative justice programmes. In doing so, I will lay the foundation for Chapter 4, in which I demonstrate there is a natural complement between prison chaplaincy and the main elements, principles and practices of modern restorative justice.

In this overview of restorative justice, I begin by reviewing some of the generally accepted definitions of restorative justice in order to highlight the main commonalities that they, or at least the schools of thought from which they spring, share. I then hone in on what I perceive to be the core elements of restorative justice, first by describing the roles of key participants in restorative justice encounters. I also consider the main principles that underpin restorative justice, its goals, and the most common processes or practices of restorative justice. 


\section{Defining restorative justice}

As mentioned in Chapter 1, there are several different definitions for restorative justice.

Nonetheless, the most widely cited definitions do not bear any sharp contradictions.

Likewise, they do contain many commonalities which become apparent upon comparison.

Tony Marshall offers a commonly cited definition of restorative justice;

Restorative justice is a process whereby all the parties with a stake in a particular offense come together to resolve collectively how to deal with the aftermath of the offence and its implications for the future. ${ }^{181}$

On the one hand, this definition appears somewhat general as it does not specify who are the parties that have a stake in a offense, nor does it provide much insight into the process itself. Marshall's definition is silent in those areas because it reflects the reality that restorative justice takes different forms in different contexts and therefore does not lend itself easily to a rigid meaning. ${ }^{182}$ It is likely that Marshall wants to present the concept in a way that does not connote any artificial, fixed boundaries thereby reflecting the true nature of restorative justice as a more fluid concept or a concept that could be applied to many different situations. If that is his intent, he finds concurrence with Llewellyn and Howse, who in their response to Marshall's definition of restorative justice state that "restorative justice does not force situations to fit theory. Rather, as a theory, it is open and flexible enough to apply on a variety of levels and to different contextual imperatives." 183

\footnotetext{
${ }^{181}$ Marshall, T., "Restorative Justice: An Overview," Restorative Justice Consortium, Social Concern. (London, England, 1998) http://2ssw.che.umn.edu/rjp/Resources/Documents/bmar98a.PDF at 1 (Accessed November 26, 2005).

${ }_{182} \mathrm{Zehr}, \mathrm{H}$., The Little Book of Restorative Justice (Intercourse: Good Books, 2002) at 36.

${ }^{183}$ Llewellyn, J.J., and Howse, R., "Restorative Justice - A Contextual Framework." (1998) This paper was prepared for the Law Commission Canada. The views expressed are those of the author and do not necessarily reflect the views of the Commission. at 19.
} 
In a similar vein, Zehr (a foremost expert in restorative justice) puts forward a more specific version of Marshall's definition which identifies some of the key principles that underpin the concept. His reformulation is as follows:

Restorative justice is a process to involve, to the extent possible, those who have a stake in a specific offense and to collectively identify and address harms, needs, and obligations, in order to heal and put things as right as possible. ${ }^{184}$

Zehr retains the notion of involving those who have a stake in the offense, with a significant a caveat ("to the extent possible"), thereby injecting an even greater degree of flexibility. He also prefers the much more specific notion of "identifying and addressing harms" to Marshall's ambiguous "dealing with the aftermath." As for what Marshall terms "the implications for the future," Zehr is more unambiguous in stating the need to identify needs and obligations in order to put things as right as possible.

A comprehensive approach to the purpose of the restorative justice process is offered by Daly:

The restorative justice process, involving as it does mediation, direct exchanges between victims, offenders, and their supporters, permits the potential for honesty and humanity to emerge in ways foreclosed in a courtroom process (or one dominated by formal legality). It is within this process where the meaning and purpose of a restorative sanction can be forged, agreed upon, and taken on by an offender for a victim (or where relevant, others). It is the understanding between an offender and victim (and often others present) of how a sanction connects meaningfully with a harm that can make a process and outcome in part 'restorative', at least ideally. ${ }^{185}$

From this it is evident that Daly conceptualizes the restorative justice process in a more elaborate way. She clearly identifies the main affected persons ("stakeholders") and describes the mechanics of an encounter. Also, from her definition it becomes evident

\footnotetext{
${ }^{184} \mathrm{Zehr}, 2002$ at 37.

${ }^{185}$ Daly, K., "Revisiting the Relationship between Retributive and Restorative Justice," in Heather Strang and John Braithwaite, eds., Restorative Justice: Philosophy to practice (Aldershot: Ashgate Publishing Ltd., 2000) at 19.
} 
that the restorative justice process is situation and context sensitive, applicable to a variety of situations where the victim, offender and the community are involved, where all three players take a central role. It is significant that she spells out who the three main affected persons are, that is, the victim, the offender and the community. Even though Marshall and Zehr do not identify the affected persons in their definitions, it is apparent in their literature that they have the same set in mind. ${ }^{186}$

The Correctional Service of Canada has also developed its own definition of restorative justice that echoes much of the above:

In the face of crime or conflict, restorative justice is a philosophy and approach that views these matters as principally harm done to people and relationships. It strives to provide support and safe opportunities for voluntary participation between those affected (victims, offenders, community) to encourage accountability, reparation, safety and movement towards understanding, feelings of satisfaction, healing and closure. ${ }^{187}$

This definition also echoes the fact that the process of restorative justice involves the victim, the offender and community members. It underscores the central principle that the offence should be viewed as a harm done to a person (rather than merely a transgression of an impersonal law). It also reiterates the basic goal of making things right, albeit in a slightly more elaborate way. Importantly, it sheds light on the requisite voluntary nature of any restorative intervention. While the other definitions presented do not stipulate this element, their authors do share in the view that participation must be voluntary. For instance, Zehr states that in all restorative justice models, victim participation must be voluntary and efforts must be made to maximize the offender's

\footnotetext{
${ }^{186}$ See for instance Zehr (2002) at 27-28, where the key stakeholders named are "victims, offenders and communities of care."

187 "With a little imagination and a lot of courage." International Perspectives on Restorative Corrections: A Review of the Literature. (2005) CSC Draft, Restorative Justice and Dispute Resolution Branch at 3.
} 
voluntary participation. ${ }^{188}$ In detailing their position on the voluntary participation of affected persons, Llewellyn and Howse speak of "protecting both victims and wrongdoers from being forced to participate." ${ }^{\text {"189 }}$ The Law Commission of Canada asserts that the free, voluntary and informed consent of victims and offenders is a procedural safeguard for the use of restorative justice. ${ }^{190}$ In spite of what appears to be a consensus among restorative justice experts on the prerequisite of voluntary participation, one needs to be mindful of the coercive nature of the prison environment and the ramifications for free choice, when discussing the application of restorative justice in the prison setting. Prisoners who choose to participate in restorative justice programmes may do so out of real or perceived pressure to participate. For example, participation in restorative justice processes in prison often factors into parole hearing decisions. ${ }^{191}$ Likewise, there are cases in which participation has led to reduced sentences. ${ }^{192}$ Prior knowledge of these possibilities puts much pressure on the prisoner when it comes time to decide whether or not to participate. For this reason, offender participation in prisonbased restorative justice initiatives may not be voluntary in the proper sense of the word.

While there is no single universal definition of restorative justice, it is apparent that the various different conceptualizations share the core elements (to be listed and discussed in the subsequent sections of this chapter). In fact, the Correctional Service of Canada (CSC) recognizes this and urges a need for understanding the roots and common core elements of restorative justice. The CSC states that "adhering to these elements is

\footnotetext{
188 Zehr, 2002 at 46.

${ }^{189}$ Llewellyn and Howse, 1998 at 62-63.

190 Transforming Relationships Through Participatory Justice (Ottawa: Law Commission of Canada, 2003) at 34.

${ }^{191}$ Van Ness, W. D., "An Overview of Restorative Justice Around the World," $11^{\text {th }}$ United Nations Congress on Crime Prevention and Criminal Justice, April 22, 2005.

192 Ibid.
} 
fundamental to ensuring that restorative justice approaches remain consistent with the philosophy underpinning it." 193 Of the definitions provided above, I favour the one put forward by the Correctional Service of Canada for its level of detail and choice of words, though I do draw upon the work of other authors in expanding upon the elements of this definition.

\section{Affected persons}

As previously indicated, one of the main ways in which restorative justice differs from the mainstream justice system is its primary concern for those who have a direct stake in a crime that has been committed, notably the victim, the offender and the community. I begin my inventory of restorative justice elements with a discussion of each of these main participants. In Chapter 4, I weigh the evidence that has been documented on the work of prison chaplains against the insights of this section, to illustrate how and to what extent prison chaplains interact with the persons affected by an offence in a way that is restorative. I would like to point out at the outset that most of the literature on restorative justice uses the term "stakeholders" for the persons affected by an offence. I do not use this term here because its true meaning does not capture the essence of the concept. It is a term that is over-used in the policy arena and lacks inclusivity. Rather, in keeping with the definition of restorative justice provided by the Correctional Services of Canada (above), I favour the term "affected persons" for those who have a stake in or are in some way affected by an offence.

193 "With a little imagination and a lot of courage." International Perspectives on Restorative Corrections: A Review of the Literature. (2005) CSC Draft, Restorative Justice and Dispute Resolution Branch at 4. 


\section{$\underline{\operatorname{Victim}(\mathrm{s})}$}

Intuitively, a victim is the person who suffered the wrong during an act of wrongdoing.

However, this basic distinction is made hazy by the restorative justice notion that each of the main affected persons, in one way or another, experienced harm as a result of the wrongdoing. ${ }^{194}$ A distinction remains nonetheless. It relies not only on the experience of harm but also on the position vis-à-vis the cause of the harm. Simply put, a victim's experience of harm is the consequence of the actions of somebody else. ${ }^{195}$

There is also a tendency in the restorative justice field to further distinguish between primary and secondary victims. Primary victims are those who are directly affected by the offence. Secondary victims are those who experience an indirect harm. While each have a stake in the restorative justice process and can in theory participate, it is generally accepted that the priority should be given to the primary victim, mainly because of the challenges involved in making adequate reparations to secondary victims. ${ }^{196}$ Naturally, this leads us into a theoretical and practical mine-field related to the identification of victims. ${ }^{197}$ How close to the offence must a victim be in order to be considered a primary victim? Which victims should be given priority in terms of reparation? If a secondary victim is anyone who experiences some indirect harm from the incident, is there really a distinction between secondary victims and the community? These questions all point to a murky gray area that restorative justice theorists and practitioners need yet to work out in order to provide for conceptual clarity.

\footnotetext{
${ }^{194}$ Llewellyn and Howse, 1998 at 45-46.

195 Ibid. at 46.

${ }^{196}$ Ibid. at 46-47.

${ }^{197}$ Miers, D., Maguire, M., Goldie, S., Sharpe, S., Hale, C., Netten, A., Uglow, S., Doolin, K., Hallam,A., Enterkin, J., and Newburn, T., "An Exploratory Evaluation of Restorative Justice Schemes," Crime

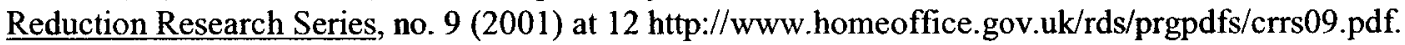


It is important to underscore that in the restorative approach, the victim has centre stage. ${ }^{198}$ This is in stark contrast to conventional justice in which victims are "largely left out of the court process, except in their role as witnesses." ${ }^{\prime 99}$ Restorative justice begins with a concern for the harm experienced by victims and their resultant needs. ${ }^{200}$ Given the purported voluntary nature of restorative justice, victims may participate directly if they so choose (and if circumstances permit), or they may participate indirectly through a representative (representative for a victim might be a parent for a young child victim ${ }^{201}$ ), particularly if the nature of their experience makes direct participation unsuitable or undesirable. $^{202}$

Questions emerge as the voluntary nature of restorative justice is mentioned; more specifically can restorative justice be applied in cases of sexual violence and child sex victims? Would a person who has experienced sexual violence or a child sex victim voluntarily participate in restorative justice process, I put emphasis on voluntary. Would the victims want to participate due to the crime being so private? According to Daly "there are just two jurisdictions in the world today - New Zealand and the Australian state of South Australia - which routinely use conferences in responding to youth sexual assault." 203 Daly continues that "in other jurisdictions, sexual offences have been

\footnotetext{
${ }^{198}$ Zehr, 2002 at 22; Daly, "Revisiting the Relationship between Retributive and Restorative Justice," in Heather Strang and John Braithwaite, eds., Restorative Justice: Philosophy to practice (Aldershot: Ashgate Publishing Ltd., 2000) at 36

${ }^{199}$ Law Commission of Canada, 2003 at 30.

${ }^{200}$ Zehr, 2002 at 23.

${ }^{201}$ Daly., K., "Restorative Justice and Sexual Assault," British Journal of Criminology (2006) at 335.

202 Morris, A., and Gelsthorpe, L., "Something Old, Something Borrowed, Something Blue, but Something New? A comment on the prospects for restorative justice under the Crime and Disorder Act 1998," Criminal Law Review (2000), at 20.

${ }^{203}$ Daly, K., "Restorative Justice and Sexual Assault," British Journal of Criminology (2006) at 334.
} 
excluded from the restorative justice agenda as they are understood to be 'too sensitive' or 'too serious' to be handled by a RJ process." 204 What is clear, however, that

"what most victims want most is quite unrelated to the law. It amounts more than anything else to three things: victims need to have people recognize how much trauma they've been through... They need to express that, and have it expressed to them; they want to find out what kind of person could have done such a thing, and why to them; and it really helps to hear that the offender is sorry - or that someone is sorry on his or her behalf." 205

When the victim chooses to voluntarily participate in the face-to-face meeting with an offender there are potential risks involved. The outcome of these meetings between the affected persons may not be as rosy as the literature of restorative justice portrays. Barbara Hudson elaborates in her article that there are common complaints. For example, due to the low prosecution rates, low conviction rates, the possibility of the 'revictimization', women during the proceedings face serious risks. ${ }^{206}$ For instance, "if the offender is acquitted or is not given a custodial sentence, they [victims] fear more violence, aggravated by the perpetrator's anger at being prosecuted." ${ }^{207}$ It may also permit power imbalances that other participants many not recognize. ${ }^{208}$ It may result in shifting the blame to a victim or the victim may be too intimidated to advocate effectively on their behalf. ${ }^{209}$ Thus, voluntary nature of restorative justice especially for the victims of sexual abuse poses some dilemmas revealing a grey area in the application of restorative justice. However, by not participating in the restorative justice process, results in the loss of an opportunity to tell their story, which "it is well known from

\footnotetext{
204 Ibid.

${ }^{205}$ Bazemore, B., "Restorative Justice and Earned Redemption: Communities, Victims, and Offender Reintegration," American Behavioral Scientist, Vol. 41. no. 6 (March 1998) at 783.

${ }^{206}$ Hudson, B., "Restorative Justice and Gendered Violence: Diversion or Effective Justice?" British Journal of Criminology (2002) at 622 .

${ }^{207}$ Hudson at 622 .

${ }^{208}$ Ibid at 337.

${ }^{209}$ Ibid.
} 
studies of victims of gendered violence, and especially sexual violence, that victims want to describe what the offender did and how it affected them." 210 Telling their story "[victims] can be empowered by confronting the offender and by participating in decision making outcomes" and "the victim's account of what happened can be validated, acknowledging that she/he is not to blame."211 Also, the process can be flexible to accommodate child sex victim's needs and capabilities, as mentioned earlier in this chapter, restorative justice "is flexible enough to apply on variety of levels and to different contextual imperatives." 212 Daly explains that "because it is flexible and less formal, it may be less threatening and more responsive ... for child and adolescent victim." 213 Thus as Hudson puts it "it remains an open question ... whether restorative justice offers better hope of protection and redress women and children." ${ }^{214}$

Therefore, voluntary nature of restorative justice, when it deals with victims of sexual violence or a child sex victim needs further empirical research, as it poses many unanswered questions and points yet to another murky area that restorative justice theorist and practitioners need to examine in the future research.

\section{Offender}

The offender is one who has inflicted harm in the course of committing an offence. In restorative justice, the offender is - along with the victim - one of the main affected persons due to his/her role in the offence and his/her own experience of harm. The

\footnotetext{
${ }^{210}$ Daly, "Restorative Justice and Sexual Assault," British Journal of Criminology (2006) at 338.

211 Ibid.

${ }^{212}$ Llewellyn, J.J., and Howse, R., "Restorative Justice - A Contextual Framework." (1998) This paper was prepared for the Law Commission Canada. The views expressed are those of the author and do not necessarily reflect the views of the Commission. at 19 .

${ }^{213}$ Daly at 338 .

${ }^{214}$ Hudson, "Restorative Justice and Gendered Violence," at 622.
} 
voluntary involvement of each is typically deemed necessary to most basic conceptualizations of restorative justice, though is not absolutely necessary in all contexts.

As opposed to the conventional justice system that focuses on the accountability of offenders based solely on punishment, restorative justice encourages offenders to understand the ramifications of their actions, empathize with victims and ultimately to "put things right." 215 The process involves addressing the harms that the offenders themselves have experienced as a result of their action (for example, alienation from the community). ${ }^{216}$ By acknowledging and addressing the affected person's injuries, restorative justice helps to empower offenders to the extent that they are able to take responsibility and become accountable for their transgressions. ${ }^{217}$ Admitting responsibility for harm(s) done is one of the core elements of restorative justice. Daly argues that "although crucial, this is commonly overlooked feature." ${ }^{, 18}$ They [offenders] are empowered through being given the opportunity to speak for themselves during the face to face meeting without any third party intermediaries (for example, lawyers) and are able to discuss their offending behaviour directly with their victims, accept responsibility for it, express remorse, apologize and attempt to make amends. ${ }^{219}$ However, Daly makes a strong point saying that "the restorative justice literature is littered with assumptions about the potential for, and the desirability of, 'reconciliation'. When considering the myriad contexts of offending and victim-offender relations, reconciliation may be

\footnotetext{
${ }^{215}$ Zehr, 2002 at 16.

${ }^{216}$ Llewellyn and Howse, 1998 at 49-51.

${ }^{217}$ Ibid. at 51.

${ }^{218}$ Daly, "Restorative Justice and Sexual Assault," British Journal of Criminology (2006) at 335.

${ }^{219}$ Morris and Gelsthorpe, 2000 , at 19.
} 
desirable in some cases, but not at all in others. ${ }^{, 220}$ Nevertheless, restorative justice advocates "hope that a victim and offender may reconcile and that a victim will recover from the offence."221 The end result is to hope that the offender will not re-offend and by taking responsibility for acts committed will "provide some form of reintegration into the community, although neither may be achieved."222 Morris and Gesthorpe concur that offenders' participation in restorative justice processes will contribute to "a better understanding of their offending and its consequences, and that, as a result of these increased understandings, the offender will be less likely to re-offend."223 However, they also acknowledge that "some steps will have to be made to put right, where possible, the circumstances which led to the offending in the first place (for example, addressing the drug and alcohol abuse and offering training or exploring job options)."224

The question whether the voluntary participation of offenders in restorative justice processes can exist in the coercive prison environment is worth examining? I will not be able to examine and provide answers to this question as literature is scarce regarding this question, however this question opens possibilities for the future research.

\section{Community}

The community is considered one of the three main affected parties because often the offense harms the community in addition to the direct victim. Also, community members quite often have a role to play in the process, ${ }^{225}$ not just in terms of having the offense

\footnotetext{
${ }^{220}$ Daly, D., "Restorative Justice and Sexual Assault," British Journal of Criminology (2006) at 336.

221 Ibid.

222 Ibid.

${ }^{223}$ Morris and Gelsthorpe, 2000, at 20.

${ }^{224}$ Ibid.

${ }^{225}$ Zehr, 2002 at 17.
} 
redressed but also in terms of supporting the reintegration of the offender. The community plays this part by determining the terms of accountability for the offender, that is, by "exercise[ing] moral authority in denouncing the crime and deciding requirements of offenders to make amends," while the state/courts function as a back-up to the community, to formalize the requirements. ${ }^{226}$ For example, in the circle approach to restorative justice, the community cooperates with the victim and the offender to decide the sentence and the court pronounces the sentence and gives it legal weight. ${ }^{227}$ In addition to determining accountability, the community also has a role in its implementation primarily by providing avenues for meaningful community service, supervising completion and providing "affirmation to offenders" for the successful completion of obligations. ${ }^{228}$ It is also the community that is best equipped to provide professional training and skills-development programs, which can aid in offender reintegration, and employment opportunities for offenders, so that they may earn a legitimate income in addition to the money for restitution. ${ }^{229}$ The community can also play a role in fostering relationships with incarcerated offenders, through various volunteer initiatives (prison ministry, one-to-one friendship programs, volunteer skills development consultations, organizational partnerships, etc.). ${ }^{230}$

"Community" is a term that is not always very useful, according to Zehr, because it is abstract, that is, it is not well defined in and of itself (with respect to boundaries, geographical scope, networks of relationships, relation to other concepts such as

\footnotetext{
${ }^{226}$ Pranis, K.., Engaging the Community in Restorative Justice, St. Paul: University of Minnesota, 1998, internet resource, http://2ssw.che.umn.edu/rjp/Resources/Documents/cpra98a.PDF at 5.

${ }^{227}$ Ibid.

${ }^{228}$ Ibid. at 9 .

${ }^{229}$ Ibid. at 10.

${ }^{230}$ Ibid.
} 
"society."231 He prefers the terms "communities of care" or "micro-communities."232 By these Zehr means more than just geographic proximity. Rather, he is interested in the networks of relationships. ${ }^{233}$ Determining who constitutes these for the purpose of practicing restorative justice involves answering two basic questions: "who in the community [writ large] cares about these people or this offense?" and "how can we involve them in the process?"234 Some authors disagree with Zehr's usage of the word "communities" and maintain that he is in fact referring to something else. They prefer the term "social networks" and contend that the term "community" should be reserved for its meaning in the broader sense. The broader community is also affected by crime albeit in ways significantly different than the social networks connected to the offender and the victim. ${ }^{235}$ The impact on the broader community is most often less direct and personal, but very real nonetheless, especially when the offence in question affects perceptions of public safety, property values, etc. While I continue to use the term "community," I do acknowledge that this term is contentious and therefore am sensitive to its use in the narrower and broader senses. I use it in both the narrow sense, as well as the broader sense, as both understandings are relevant to this discussion, however I clarify my usage in each instance.

\footnotetext{
${ }^{231}$ Zehr, 2002 at $27-28$.

232 Ibid.

233 Ibid.

${ }^{234}$ Ibid. at 28.

${ }^{235}$ Umbreit, S. M., Coates, B. R. and Vos, B., "Restorative Justice versus Community Justice: Clarifying a Muddle or Generating Confusion?" Contemporary Justice Review vol. 7, no. 1 (March 2004) at 84-85.
} 


\section{Main principles of restorative justice}

Drawing mainly upon the work of Zehr and the Correctional Service of Canada, I distil the following set of basic principles of restorative justice. It is my intention to use these, along with other elements of restorative justice, to assemble a range of criteria or indicators against which activities may be compared in order to better understand how they relate to or perhaps complement restorative justice. These principles of restorative justice will serve as part of the litmus test for the restorative aspects of prison chaplaincy in Chapter 4.

\section{$\underline{\text { Harms and needs }}$}

Restorative justice focuses on the harms (offender's negative impact on victims, the direct community and beyond) and consequent needs of victims, as well as those experienced by the community and even the offender. ${ }^{236}$ In the restorative approach, crime is foremost understood as harm done to people and communities rather than rule or law-breaking. Practitioners and proponents of restorative justice seek to address the harm both in concrete terms and symbolically by honing in on the needs of victims. ${ }^{237}$ The victim explains how he/she was violated and, in doing so, initiates the dialogue concerning the transgression that has occurred as well as what needs to be done in order to put right the wrongs. ${ }^{238}$ As mentioned previously, restorative justice also recognizes that, as a result of the commission of a crime, the community and the offender him/herself experience harm, usually because of the disruption of the social fabric. That

\footnotetext{
${ }^{236} \mathrm{Zehr}, 2002$ at 32.

${ }^{237}$ Ibid., p 22.

${ }^{238}$ Hudson, B., "Restorative Justice: The Challenge of Sexual and Racial Violence," Journal of Law and Society, vol. 25, no. 2 (June, 1998) at 241.
} 
is, the harm perpetrated by the offender creates a situation of anger, antagonism and ongoing conflict. Restorative justice seeks to restore the social fabric and to mend the harm. This focus on the harm and related needs, rather than on the rules, immediately compels a transformation of the perception of the transgression, from the perspective of the offender. The act suddenly becomes very personal and very real, as the offender is brought to understand that his/her actions have harmed real people. The victim and members of the immediate community also have an experience not often accorded in the conventional justice system in that they are given a central opportunity to participate in the process and to directly express their experience.

\section{$\underline{\text { Remorse }}$}

It is not enough for the persons affected by an offence to come to understand the act as harm done to people and not mere rule-breaking. The offender in particular needs to articulate this understanding and express remorse for the harm that he/she has caused, because an expression of genuine remorse is an "initial movement towards reparation.,"239 Also, when the offender expresses remorse and offers an apology and "knows that forgiveness has occurred, [it] may have important implications for the perpetrator's selfimage." 240 Estrada-Hollenbeck argues further that "the affect change is less dramatic for the perpetrator, but knowledge of forgiveness does affect the perpetrator's emotions such that he or she feels less negatively when he or she recalls situations in which the victim

\footnotetext{
${ }^{239}$ Daly, 2000, at 43 .

${ }^{240}$ Estrada-Hollenbeck, M., "Forgiving in the Face of Injustice: Victims' and Perpetrators' Perspectives" in Restorative Justice: International Perspectives edited by_Galaway B., and Hudson J., (Kugler Publications and Criminal Justice Press, 1996) at 311.
} 
forgave, than when the victim did not forgive."241 However, the author also argues that "the issue remains unresolved, and that justice is not truly restored as long as the perpetrator is oblivious of the victim's forgiveness process. ${ }^{, 242}$ Annalise Acorn further states that "the significance of forgiveness to restorative justice lies in its possible contribution to the ultimate restorative goal of right-relation - that is, a lived relationship of mutual equality and respect." 243 Therefore, "in this way, forgiveness is a contributor to the restoration of justice to the extent that it restores a neutral or positive relationship between the victim and perpetrator."244

In order for victims to let go of the anger and fear that is often part of victimization, they need to hear the offender express remorse and apologize for his/her actions. $^{245}$ It allows for an "amelioration of the victim's sense that they have been wronged," which in turn makes it more possible for victims to "let go of the anger and fear that is part of victimization."246 For these reasons, a true sense of remorse by the offender is a prerequisite for successful restorative justice. Therefore, remorse for harm(s) must also be considered a central principle in restorative justice. Given that this principle is so crucial to the overall enterprise of restorative justice, the extent to which (if any) that prison chaplains facilitate a true sense of remorse among the offenders that they work with is a key consideration in evaluating the restorative role of prison chaplains and will be given due attention in Chapter 4.

\footnotetext{
241 Ibid.

242 Ibid.

${ }^{243}$ Acorn, A., Compulsory Compassion (UBS Press: Vancouver, 2004) at 11.

${ }^{244}$ Estrada-Hollenbeck, M., at 312.

${ }^{245}$ Brunk, G. C., "Restorative Justice and the Philosophical Theories of Criminal Punishment," in Michael L. Hadly, ed., The Spiritual Roots of Restorative Justice (Albany: State University of New York Press, 2001) at. 52 .

246 Ibid.
} 
Naturally, a question arises as to the ability to judge whether a person is truly remorseful. After all, a sincere apology prefaced by a sincere statement expounding one's understanding of the impact of the offence can be feigned. While often times false contrition is detectable, some people are no doubt masters of deceit and can conceivably put on a show of remorse, just so that they can play the game in an attempt to evade further punishment. This reality needs to be borne in mind by restorative justice practitioners as it poses a problem for the restorative justice approach. The question whether the offender is genuinely remorseful will be examined in greater detail in Chapter 4 .

\section{Obligations/accountability}

In the traditional justice system, punishment is carried out through incarceration as the primary means of sanctioning offenders for violations against the state. ${ }^{247}$ In restorative justice punishment is carried out through "accountability for crime as the obligation of offenders to make amends to victims." ${ }^{248}$ A major principle of restorative justice is the imperative to create an understanding of the obligations that result from the harms that result from transgressions (that is, those of the offender, community, society). ${ }^{249}$ The harms and needs necessarily give rise to obligations. One of the chief concerns of restorative justice is the creation of means for offenders to take responsibility for their transgressions, directly in front of those who have been harmed. ${ }^{250}$ This often involves

\footnotetext{
${ }^{247}$ Bazemore, G., "Three Paradigms for Juvenile Justice," in Restorative Justice: International Perspectives, edited by Galway, B. and Hudson, J. (NY: Criminal Justice Press, 1996) at 20.

248 Ibid. at 20 .

249 Zehr, 2002 at 33.

${ }^{250}$ International Perspectives on Restorative Corrections: A Review of the Literature (draft), Restorative Justice and Dispute Resolution Branch, Correctional Services Canada, 2005, at 5.
} 
the offender personally (that is, not through a representative) explaining his/her behaviour to the victim and community members. ${ }^{251}$ Also, according to Bazemore, "performance objectives in restorative justice are driven by the needs of victims for material, physical, and emotional restoration and involvement, and simultaneously, the need for offenders to understand the consequences of their actions and to actively make amends for the harm done."252

However, there are limitations, as mentioned earlier in the chapter, this may not apply to offenders of sexual assault, thus leaving them excluded out of the restorative justice face-to-face conferences as the nature of such encounters are understood to be "too serious."

\section{Righting the wrongs}

Another main principle of restorative justice that emerges from the act of accountability is the need to put right the wrongs that have been committed through an offence. ${ }^{253}$ The outcomes sought through restorative justice encounters include "healing, personal growth, reparation of harms, restoration of positive relationships and creation/recreation of enhanced personal and communal situations." 254 Thus, righting the wrongs of an offence or repairing harm caused by a crime to the victim and community can come in two general forms: meaningful reparations and the restoration of damaged community networks. In other words, according to Paul Skanks, an offender has to earn his/her way

\footnotetext{
${ }^{251}$ Cooley, D., Restorative Justice in Canada: Lessons Learned (Ottawa: Law Commission of Canada, 2002) at 7.

${ }^{252}$ Bazemore 1996 at 20.

${ }^{253}$ Zehr, 2002 at 33.

${ }^{254}$ International Perspectives on Restorative Corrections: A Review of the Literature (draft), Restorative Justice and Dispute Resolution Branch, Correctional Services Canada, 2005, at 6.
} 
back into community. An offender has to demonstrate that he/she is willing to change, to restore. ${ }^{255}$ Further, "in the eyes of the offender, there needs to be a clear connection established between the crime committed and the measures carried out to 'make things right. ${ }^{256}$ Therefore, the active participation of the offender, victim and the community in establishing what reparative actions need to be taken is a crucial element in restorative justice. ${ }^{257}$ If and how prison chaplains effect change in both respects is another consideration when weighing the overall restorative attributes of their office.

\section{Inclusive, collaborative processes}

The use of inclusive, collaborative processes is an important principle of restorative justice. ${ }^{258}$ Inclusion gives voice, accessibility, ownership of the process and support to everyone who takes part. ${ }^{259}$ The communication that is engendered through restorative justice may take many formats in addition to the face-to-face encounters, including correspondence, video exchanges, shuttle communication, online discussions and multiparty representation. ${ }^{260}$ Inclusion also means participation in a meaningful way. It is therefore pertinent to consider if prison chaplains open up such alternative channels of meaningful communication. Whether they in fact help give voice, accessibility, ownership of the process and support to any of the affected persons of a particular offence would lend further credence to the argument of this thesis. This point will be examined in Chapter 4.

\footnotetext{
${ }^{255}$ Skans, P. Interview with the author, Ottawa, ON, September 12, 2006.

${ }^{256}$ Bazemore, 1996 at 20.

${ }^{257}$ Bazemore, 1996 at 20.

${ }^{258}$ Zehr, 2002 at 33.

${ }^{259}$ International Perspectives on Restorative Corrections: A Review of the Literature (draft), Restorative Justice and Dispute Resolution Branch, Correctional Services Canada, 2005, at 5.

${ }^{260}$ Ibid at 7.
} 


\section{Affected persons involvement}

One of the key principles that sets restorative justice apart from the prevailing law-based system is that it involves, or at least seeks to involve, all of the affected persons, that is, those with a stake in the situation, including victims, offenders, community members and society. ${ }^{261}$ Restorative justice attempts to directly engage all of the people affected by an offence. In addition to the victim, offender and community, these may include their individual support people, such as family and friends. ${ }^{262}$ Doing so brings them into the middle of the process of justice, whereas in the conventional approach many, including the victim, would remain on the sidelines.

However, it is not clear from the literature who determines the participation of affected persons? Also, what happens when the number of affected persons who would like to participate in restorative justice might be too large for the restorative justice process to handle? Then who gets to decide who has been affected by crime more and who has been affected less and therefore, who gets to be invited to participate? These questions are beyond the scope of my research and I do not attempt to answer them, however it does open up some grey areas in restorative justice that require clarification and attention in the future research.

While it is apparent that prison chaplains interact with at least one set of affected persons by virtue of their pastoral mandate to prisoners, the argument that they are significant agents of restorative justice will be further bolstered by examining patterns of interaction with other affected persons as they minister to the prison community.

\footnotetext{
${ }^{261} \mathrm{Zehr}, 2002$ at 33

262 International Perspectives on Restorative Corrections: A Review of the Literature (draft), Restorative Justice and Dispute Resolution Branch, Correctional Services Canada, 2005, at 4.
} 


\section{Goals of restorative justice}

In addition to the basic restorative justice principles outlined above, a congruence of goals between restorative justice and prison chaplaincy would offer yet further support to the thesis. Surely prison chaplains' work may be deemed parallel to restorative justice if they are working towards some or all of the same goals.

What are the basic goals of restorative justice? It is useful to conceive of the goals of restorative justice both in terms of process and outcome, as restorative justice is concerned with its ends as it is with the means to those ends. According to Zehr, restorative justice programs strive to put key decisions into the hands of those most affected by crime (process); make justice more healing and, ideally, more transformative (outcome); and reduce the likelihood of future offences (outcome). ${ }^{263}$ (On the critical note, Zehr does not provide an explanation on who determines who has been most affected by crime.) The Law Commission of Canada puts forward a rather different, albeit complementary, set of objectives of restorative justice, also which can be divided according to process and outcome. It lists as restorative justice objectives denouncing unacceptable behaviour (process); supporting victims (process); reforming individual offenders through active responsibility taking (process); restoring community order and peace (outcome); and identifying restorative, forward-looking outcomes (process). ${ }^{264}$ I would like to stipulate another goal that pertains specifically to restorative justice in the prison setting, that of the need for offenders to engage in "self-

\footnotetext{
${ }^{263}$ Zehr, 2002 at 37.

${ }^{264}$ Law Commission of Canada, 2003 at 44-45.
} 
restoration". ${ }^{265}$ This goal is deemed important to the restorative justice process in prisons in that it is often a precondition for meetings with victims.

\section{Some hallmarks of an effective restorative justice practitioner in the prison setting}

This thesis straddles two spheres: the context of traditional prison chaplaincy and the context of prison chaplain participation in formal restorative justice programmes. While the above discussions serve to distill elements of restorative justice relevant to the examination of the restorative nature of the work of prison chaplains in the first context, these do not on their own suffice for the examination of the restorative role of prison chaplains working in the second context. For this, it is necessary to consider a set of hypothetical endowments - related to the core philosophy of restorative justice, the realities of the prison environment and professional abilities - that would render someone an effective practitioner of restorative justice. I propose three: a unique restorative justice niche, an institutional ability to broker restorative justice options and a professional ability to facilitate greater healing.

\section{Unique niche}

Restorative justice, by its very nature is a holistic approach to justice. ${ }^{266}$ It is predicated on the holistic view that everything - people, land, structures, God - are interconnected and that this web of relationships is disrupted when harm is committed. ${ }^{267}$ Given this

\footnotetext{
${ }^{265}$ International Perspectives on Restorative Corrections: A Review of the Literature (draft), Restorative Justice and Dispute Resolution Branch, Correctional Services Canada, 2005, at 52.

${ }^{266}$ Guest, J.R.J., “Aboriginal Legal Theory and Restorative Justice, part 2," Justice as Healing vol. 4, no 2 (1999), http://www.usask.ca/nativelaw/publications/jah/guest2.html.

${ }^{267}$ Sawatsky, J., “A Shared Just Peace Ethic: Uncovering Restorative Values," Conciliation Quarterly vol. 20, no. 3 (March 2002), http://www.restorativejustice.org/articlesdb/articles/779/view? searchterm=holistic.
} 
encompassing, holistic nature, restorative justice encounters cross into numerous areas of professional competence, including law, psychology, social work, spirituality, etc.

Within all of this, do prison chaplains occupy a unique niche that cannot be fully served by other professionals working in the field of restorative justice?

\section{Making restorative justice available to inmates}

The prison setting poses inherent obstacles to the practice of restorative justice. Prison regimes make it difficult for inmates to exercise personal responsibility and experience a necessary degree of autonomy. ${ }^{268}$ Likewise, the prison subculture is often not conducive to restorative justice in that it makes a rejection of deviance difficult for prisoners. ${ }^{269}$ Also, the use and threatened use of force within prisons (by prison staff and among inmates) makes it difficult to accept the peaceful recourse of restorative justice. ${ }^{270}$ Complicating things further is the fact that inmates and prison administrators often do not share the same goals, thus making a single restorative purpose difficult to maintain. ${ }^{271}$ Also, prisons are focused on the offender and therefore make it difficult to inject the voice and needs of the victim and other affected persons into restorative efforts. ${ }^{272}$ Whether the institutional position of the prison chaplain accords him/her with the ability to bring restorative options to inmates is therefore a key consideration in positing the significance of his/her role as a formal practitioner of restorative justice.

\footnotetext{
${ }^{268}$ Van Ness, W. D., "Restorative Justice in Prisons," Restorative Justice Consortium (July, 2005) http://www.restorativejustice.org.uk/Resources/pdf/RJ_in Prisons_Dan_Van_Ness_05.pdf, at 5. ${ }^{269}$ Ibid.

${ }^{270}$ Ibid.

${ }^{271}$ Ibid.

${ }^{272}$ Ibid.
} 
Making the process more healing

In considering the efficacy of a restorative justice practitioner, perhaps the most significant matter is whether he/she is actually able to make the process more healing. Is there something about his/her profession that suits him/her to contribute significantly to the process?

The theoretical framework provided in this chapter is applied in Chapter 4 where I assemble the data on prison chaplains and highlight the parallels with restorative justice. 


\section{Chapter 4: Restorative Justice Role of Prison Chaplains}

This chapter will provide an opportunity to evaluate the restorative justice role of prison chaplains. Specifically, two central questions will be answered. First, whether prison chaplains operating outside the framework of formal restorative justice initiatives engage in the major elements of restorative justice simply as part of the their regular pastoral duties. Second, whether those who do purposefully engage in restorative justice are particularly good at it due to their position and role as chaplains. I look at the duties, responsibilities and services of prison chaplains for evidence. The data for this chapter comes from a variety of sources, including interviews with prison chaplains and experts in the field of restorative justice. It is assembled according to the framework established in Chapter 3, which is based on the existing literature on restorative justice. I start off the discussion by reviewing the general role and mandate of prison chaplains. The rest of the Chapter is organized into two major sections which specifically highlight the congruencies with restorative justice principles and practices. The first of these sections looks at the work of prison chaplains in a conventional correctional setting, where no formal attempts at restorative justice are made. I argue here that, by the very nature of the office of the prison chaplain, there is natural complement between prison chaplaincy and the main elements, principles and practices of modern restorative justice as these are developed in the existing literature of the field. The second section looks at the participation of prison chaplains in actual restorative justice practices. The goal of that section is to develop an understanding of the real-world potential and significance of prison chaplains in restorative justice. The evidence assembled in both sections will 
combine to make the case that prison chaplains are significant agents for restorative justice.

\section{General role and mandate of prison chaplains}

In a survey conducted for the Chaplaincy Impact Study - a component of the Results Based Management Accountability Framework developed by the Chaplaincy Branch and the Evaluation and Review Branch of the Correctional Service of Canada - offenders were asked whether faith or spirituality play a role in their lives. Eighty nine percent answered in the affirmative. ${ }^{273}$ This statistic alone bears witness to a very real dimension of the experience of those incarcerated in Canada's correctional institutions. It is the related needs of this spiritual dimension that form the raison d'etre of prison chaplaincy. Tending to the spiritual needs of prisoners, then, is what prison chaplains do. But is that all that they do? And what does it mean to tend to spiritual needs? What are the specific roles and responsibilities of prison chaplains?

Turning to the Correctional Service of Canada for a more concrete understanding of the role of prison chaplains, we are presented with a fairly concise definition. In the CSC's on-line documentation, under the heading of "Role of Chaplains," it is merely stated that "[c]haplains operating in CSC facilities provide spiritual guidance to members of all religious traditions. [...] In general, chaplains are responsible for maintaining a visible presence at the institutions."274 The latter part of the definition includes directing and coordinating religious/sacramental services and activities to inmates; relating the

\footnotetext{
${ }^{273}$ Chaplaincy Impact Study, Correctional Service of Canada http://www.cscscc.gc.ca/text/prgrm/chap/pastoral care report e.shtml

274 "Role of Chaplains," Correctional Service of Canada http://www.csc-scc.gc.ca/text/prgrm/chap/pro062 e.shtml
} 
needs and concerns of persons affected by the criminal justice system to the community, including the community's role in reconciliation; recruiting volunteers for prison work; and integrating chaplaincy services into the life of the institution. ${ }^{275}$

Although this definition does not provide a detailed picture of the day-to-day work of prison chaplains, which would allow us to understand better what exactly they do, it nonetheless provides some useful information. For instance, from this definition, we are reminded that the pastoral services of chaplains must be made available to all inmates, regardless of their respective faiths, that is, a chaplain must serve not only inmates of his/her respective faith tradition, but also individuals of other faiths if these request his/her services. As mentioned in the earlier chapter, restorative justice procedures and applications must also be flexible enough to respond to the particular exigencies, personal needs and potential for action in each case. ${ }^{276}$ Therefore, this point is significant because it indicates that prison chaplaincy is akin to restorative justice in terms of its flexibility and individual treatment of individual cases. Its broad application across denominational lines also makes it relevant to the secular justice system.

Notable too is the brief but very significant mention of the chaplain's role in reconciliation. The definition provided above does not elaborate on the prison chaplain's role in reconciliation. However, the mere presence of the word suggests that the chaplain is involved in something quite different from the conventional justice system in which his/her career is nested. Furthermore, it is common knowledge that reconciliation and

\footnotetext{
${ }^{275}$ Ibid.

${ }^{276}$ Marshall, T., "Restorative Justice: an Overview," A Report by the Hope Office Research Development and Statistics Directorate, $1999 \mathrm{http} / /$ members.lycos.co.uk/lawnet/RESTRJUS.PDF at 9.
} 
restoration are kindred concepts. ${ }^{277}$ When at least one of the affected persons of an act of wrongdoing (for example, victim, member of the proximate or broader community) is reconciled with the offender, a major stride in the direction of restoration is made. For example, in victim's words:

"It was not easy to look at [the burglar] directly. This was a person who had invaded our privacy, desecrated our home and caused us great heartache, disruption and anger...He described how he had been on drugs and alcohol for several days and had picked our house at random... He described his fear... and that he was very sorry for what he had done.... As the [meeting] went on it became...more of a conversation... The most important effect for all of us was, I suspect, that we were able to move on from our fantasies. The imaginary picture we had of the man who had invaded our home was undermined by the welldressed, calm, articulate person in front of us. Similarly I suspect our readiness to want the best for him without expressing anger or bitterness was a help to [him]. We left feeling that there was hope for the future and that maybe our meeting had helped him to take a step forward. It had certainly helped us to come to terms with what had been a very traumatic and painful experience." 278

However, it is important to highlight the ambiguity in the literature of restorative justice. Aside from the fact that one of the main restorative justice practices is called "Victim-Offender Reconciliation" (see Chapter 1), the linkage between the two concepts by using the word "restore" in a definition for "reconcile," that is, "to restore to friendship or to harmony" often times, the two words are used side-by-side in a variety of contexts, but especially in the restorative justice context. While all of the instances are far too numerous to list, a few examples are Restorative Justice, (John Howard Society of Albert, 1997), Lorraine Stutzman Amstutz and Howard Zehr in Victim Offender

\footnotetext{
${ }^{277}$ Restorative Justice, (John Howard Society of Albert, 1997) http://www.johnhoward.ab.ca/PUB/PDF/C26.pdf at 8; Lorraine Stutzman Amstutz and Howard Zehr, Victim Offender Conferencing: In Pennsylvania's Juvenile Justice System (Mennonite Central Committee, 1998) http://www.mcc.org/us/peaceandjustice/voc.pdf at 35; and "Participant's Guide - Appendix," in Facilitating Restorative Group Conferences, Minnesota Department of Corrections, January 2003, http://www.doc.state.mn.us//rj/facilityconference/2003/PG\%207\%20App\%20-\%201-03.pdf at 7.19.

278 "Law, Victims and the Vulnerable," Prison Reform Trust, http://www.ws3.prisonreform.web.baigent.net/subsection.asp?id=708 at 12 .
} 
Conferencing: In Pennsylvania's Juvenile Justice System (Mennonite Central Committee, 1998) and "Participant's Guide - Appendix," in Facilitating Restorative Group

Conferences, Minnesota Department of Corrections. What is not clear from the research, however, is whether the two words used interchangeably in the literature of restorative justice share the same meaning and target to achieve same end result in the processes of restorative justice. Therefore, a lack of clear definition between the two concepts demonstrates a gap in the literature of restorative justice which restorative justice theorist and practitioners need to work out in order to provide conceptual clarity.

It should not go unnoticed that the role of the chaplain, according to the earlier provided definition, consists of liaison with the community, both in terms of educating the community about the effects of the justice system and in terms of seeking out individuals from the community to serve as volunteers. This facilitation of the interaction between the community and the correctional environment potentially provides an avenue for the interaction of affected persons, that is, the victim, the offender and the community. Whether this actually serves restorative ends is to be seen. However, the potential needs to be acknowledged.

The stipulation that chaplains must integrate their services with the life of the institution by interfacing and coordinating with prison staff, is also worthy of note. This is reflective of the history of prisons, in which clergy traditionally have had a prominent role right from their inception. Also, according to Pierre Allard and Wayne Norhey "[it] is certainly clear that the persecuted church quickly became the persecutor in its response to pagans, Jews, other outsiders, and eventually criminals. ${ }^{279}$ In fact, Kelly Hannah-

\footnotetext{
${ }^{279}$ Allard, P., and Northey, W., "Christianity: the Rediscovery of Restorative Justice" in Michael L. Hadley eds., Spiritual Roots of Restorative Justice (Albany: State University of New York Press, 2001) at 126.
} 
Moffat says that "[r]eligious ideas and agendas were central, not peripheral" to the punishment trends that prevailed before the era of large-scale incarceration. ${ }^{280}$ Furthermore, in those early days, it was merely a given that the institutionalized faith community was "the guardian of moral order and stability" and that it had a significant role in "the treatment of those who threatened to upset this moral order and stability."281 The forms of punishment had a religious air to them, bearing concepts of "mercy, pardoning, and sympathy" and incorporating rituals of confession and penitence along side of corporal and capital punishment. ${ }^{282}$

Though some of this history continues to resonate, much has changed and evolved since those early days. Prison chaplains today are concurrently part of the system and apart from it. ${ }^{283}$ As such, they operate within the context of the formal, secular justice system, all the while offering an avenue for personal reform that is quite different from merely doing the time that was meted out as part of a sentence handed down by a secular court. This parallels with restorative justice, which, although increasingly accepted in the mainstream, nonetheless distinguishes itself as a non-conventional approach to justice, which likewise emphasizes transformation on a personal level.

Additional details concerning the role of prison chaplains are present in other documents. These documents provide further evidence of the parallels between restorative justice and prison chaplains noted above and reveal additional ones. For instance, the chaplaincy Statement of Ethics underscores several of the points discussed above. It states that a chaplain is responsible for providing services to people of other faith traditions, while

\footnotetext{
${ }^{280}$ Hannah-Moffat, K., Punishment in Disguise: Penal Governance and Federal Imprisonment of Women in Canada (Toronto: University of Toronto Press, 2001) at 31.

281 Ibid.

${ }^{282}$ Ibid.

${ }^{283}$ Chaplaincy Impact Study.
} 
respecting their practices and beliefs, and not imposing his/her faith tradition on them. ${ }^{284}$ Also, it touches on the community dimension of a prison chaplain's work, noting that the prison ministry is "the work of the whole faith community," but because of the special circumstances of the correctional setting, prison chaplains are responsible for giving "shape and content to this work." 285 This point is reiterated in the 2002 Memorandum of Understanding Between the Interfaith Committee on Chaplaincy and the Correctional Service of Canada. ${ }^{286}$ Additionally, a chaplain must remain involved with his/her own faith community outside of prison. ${ }^{287}$ Furthermore, the statement reiterates the necessity of teamwork with chaplains of other faith communities and prison staff. ${ }^{288}$

The Statement of Ethics states that at the core of the ministry of prison chaplaincy is a "full biblical concept of justice." 289 As demonstrated in Chapter Two (please see the discussion on "Judeo-Christian roots"), justice in the biblical sense has much in common with restorative justice. Here is a potentially profound parallel between the ministry of prison chaplaincy and the modern restorative justice movement. It is not astonishing then, that the same document acknowledges the "restorative justice paradigm" and encourages a commitment to it. ${ }^{290}$

A chaplain who is approved to minister (Correctional Services and the faith communities share the responsibility for the selection and termination of chaplains) in the prison setting is granted the right to hold regular services, as well as to pay pastoral visits

\footnotetext{
284 "Statement of Ethics" Correctional Service of Canada http://www.cscscc.gc.ca/text/prgrm/chap/soe_e.shtml.

285 Ibid.

286 "Memorandum of Understanding Between the Interfaith Committee on Chaplaincy and the Correctional Service of Canada" Correctional Service of Canada, 2002, http://www.csc-

scc.gc.ca/text/prgrm/chap/mou_e.shtml.

287 "Statement of Ethics".

288 Ibid.

${ }^{289}$ Ibid.

${ }^{290}$ Ibid.
} 
in private to inmates of his or her religious affiliation. ${ }^{291}$ Inmates may, in fact, request the provision of specific religious rites and the chaplain must invite a leader from the appropriate denomination to attend if the chaplain himself or herself cannot see to the request. $^{292}$ Thus, with respect to his/her ministering to the spiritual needs of the inmates, the chaplain has a dual role: that of presiding over or officiating at official denominational services and interfacing on a more direct, one-on-one basis with inmates, or at least facilitating such encounters. Both may nourish the spiritual needs of inmates and both may provide distinct avenues for learning, understanding, spiritual and moral growth, conversion, and reconciliation, all of which may be the first steps towards restoration. These chaplaincy activities often involve volunteer members from the community and thus pave the way for a form of community interaction with inmates. As with restorative justice activities, the participation of offenders in prison chaplaincy activities is voluntary. ${ }^{293}$

Whether directly pertinent to the discussion on restorative justice or not, the Statement of Ethics, the Memorandum of Understanding and the Ontario Policy and Procedures Manual shed additional light on prison chaplaincy and this is beneficial to the ensuing discussion. Chaplains are typically contractors. They are hired by contract with their respective faith community and remain employees of their respective religious authority. ${ }^{294}$ A prison chaplain is to be a "person of God,"295 or to put it in more secular parlance, it is someone who is committed to and espouses a particular faith tradition.

\footnotetext{
291 "Memorandum of Understanding Between the Interfaith Committee on Chaplaincy and the Correctional Service of Canada."

292 "Religious services and spiritual care," Adult Institutions Policy and Procedures Manual, (Ontario Ministry of Public Safety and Security, Correctional Services Division, July 2004). 293 Ibid.

294 "Memorandum of Understanding Between the Interfaith Committee on Chaplaincy and the Correctional Service of Canada".

295 "Statement of Ethics."
} 
$\mathrm{He} /$ she must be professionally trained so as to provide effective pastoral care. ${ }^{296}$ In terms of personal qualities, a chaplain must be humble, generous, open-hearted (without prejudices), and hopeful in the transformative power of God. ${ }^{297}$ This character profile is of relevance to the discussion not only because it shows what sort of person is ideally sought for the position, but also points to some of the linkages with restorative justice discussed further on.

There is one prison chaplain for every 150 to 200 inmates. $^{298}$ In addition to providing religious services and individual pastoral care, chaplains help ensure that prisoners with special faith-based dietary requirements receive meals that conform to their religious affiliation. ${ }^{299}$ Chaplains are informed when inmates experience serious injury, illness, hospitalization or death and are often present when the inmate's next of kin/significant other are informed of the occurrence. Likewise, a chaplain is notified when an inmate has a family crisis and is often present when the news is relayed to the inmate. $^{300}$ Often, chaplains are involved in inmate discharge planning. ${ }^{301}$ Prison chaplaincy is considered an essential service, ${ }^{302}$ mostly because it is integral to the correctional system and because of the possibility that human life would suffer in the event that the duties of these employees were interrupted. ${ }^{303}$

\footnotetext{
${ }^{296}$ Ibid. and "Memorandum of Understanding Between the Interfaith Committee on Chaplaincy and the Correctional Service of Canada".

297 "Statement of Ethics."

${ }^{298}$ Memorandum of Understanding Between the Interfaith Committee on Chaplaincy and the Correctional Service of Canada".

299 "Religious services and spiritual care."

${ }^{300}$ Ibid.

301 Ibid.

${ }^{302}$ Memorandum of Understanding Between the Interfaith Committee on Chaplaincy and the Correctional Service of Canada".

${ }^{303}$ A concise explanation of "essential services" is provided by the Treasury Board Secretariat in "Guidelines for Essential Services Agreements," Treasury Board Secretariat, http://www.tbssct.gc.ca/pubs_pol/hrpubs/TBM_11B/esa-ese01_e.asp.
} 
Clearly, the mandate of prison chaplains is broad and by nature shares some interesting parallels with the principles of restorative justice. Sociological evidence reveals that prison chaplains have a significant impact upon the prisoners that they minister to. ${ }^{304}$ That they are also significant agents for the restorative paradigm is demonstrated by the evidence assembled below.

\section{Prison chaplains and restorative justice: the conventional setting}

While a few of the parallels between prison chaplaincy and restorative justice have already been drawn, they are not on their own sufficient to conclusively make the case that prison chaplains are formidable agents of restorative justice. A closer look is needed at examples of the actual work of prison chaplains in order to prove that these parallels are more than mere coincidences and that the complement between prison chaplaincy and restorative justice in fact runs deep. A closer look at chaplains working in the conventional corrections setting, that is, those engaged in the typical work of prison chaplains and not participating in explicitly "restorative justice" initiatives serves this end.

The chaplain, the prisoner and other participants

Perhaps a good starting point is to reflect in more detail on who it is that the prison chaplain works with in the course of executing his/her duties. Is the prison chaplain's ministry directed towards one or more of the affected persons of an offence/conflict, as

\footnotetext{
${ }^{304}$ One study found that among former prisoners who credited members of the prison staff for their postrelease success, one sixth cited prison chaplains, even though they comprised less than one percent of staff. Also, chaplains were the second most frequently cited staff members credited with fostering prisoners' rehabilitation. Other studies indicate that participation in chaplaincy programs improves prisoners' institutional adjustment and reduces recidivism. See Sundt and Cullen at 370.
} 
these are understood in the restorative justice paradigm? There are strong hints to that effect in discussions earlier in this and in previous chapters. At this juncture, I lay out the evidence that substantiates the point that prison chaplains do in fact interact with some of the most affected persons.

It is obvious that, in fact, the prison chaplain's ministry is intended for at least one of the affected persons, that is, the offender who is incarcerated in a correctional facility. At first glance, this self-evident fact may lead one to overlook the other people in the corrections environment, namely the staff, as well as those members of the community whom the chaplain interacts with in his/her professional capacity, and thus cause one to assume that the prison chaplain serves incarcerated offenders exclusively. That, however, would not be reflective of reality. Chaplaincy programs vary one from the other. Some, granted, are more inward focussed, that is, on matters internal to the penitentiary, while others have substantive external outreach. But even the former are not totally isolated from the outside world, mandating the prison chaplain to interact with members of the outside community, even if in a limited way. And their work certainly extends beyond service to inmates, providing for a "safe non-judgemental space" for both inmates and staff. ${ }^{305}$ This is corroborated by Rev. Carl Wake, Coordinating Chaplain at the Ottawa Carleton Detention Centre, who explains that he is formally responsible for "the provision of spiritual care and religious services [...] at the Detention Centre and that involves inmates, staff, administration and all of our families. ${ }^{306}$ On occasion, he is contacted by distraught family members of an inmate and is asked to relay sad news (for

\footnotetext{
${ }^{305}$ Staffand inmate family support is part of the Pastoral Care component of chaplaincy. See "Evaluation Report: Chaplaincy EXCOM Presentation."

${ }^{306}$ Wake, C., interview with the author, Ottawa, ON, April 26, 2005.
} 
example, a death in the family) and to be with the inmate to make sure he or she is alright. $^{307}$

The more outward reaching programs draw upon the services of community chaplains and are geared towards helping the inmate reintegrate into the community after his/her release and often facilitate discussions between the inmate and his/her family (at the inmate's request), giving the inmate an opportunity to patch damaged relationships prior to his/her release. ${ }^{308}$ In fact, many prison chaplains provide counselling and help to the families of inmates. ${ }^{309}$ Rev. Dr. Pierre Allard, Assistant Commissioner for Community Engagement at the Correctional Service of Canada and long-time prison chaplain, affirms that traditionally prison chaplaincy is very much a link between inmates and the outside world. ${ }^{310}$ Evidently the work of prison chaplains is not limited to interfacing with prisoners and often involves other affected persons, primary and secondary.

As discussed in the previous chapter, the community is one of the affected persons involved in any given offence and consists of both the social network of the offender and the broader community within which that network is nested. Therefore, a prison chaplain's interaction with members of the community may entail linkages with primary and/or secondary victims of an offence. Also, volunteers both in the past and in the present have been important partners of prison chaplains and their involvement in the prison ministry is one way in which their respective churches and religious bodies can

\footnotetext{
307 Ibid.

${ }^{308}$ Skaljin, M., interview with the author, Ottawa, ON, June 26, 2005.

${ }^{309}$ Sundt and Cullen, "The correctional ideology of prison chaplains: A national survey," Journal of Criminal Justice no. 30 (2002) at 370.

${ }^{310}$ Rev. Dr. Allard, P., interview with the author, Ottawa, ON, April 8, 2005.
} 
take on a greater role in helping inmates. ${ }^{311}$ Rev. Carl Wake, Coordinating Chaplain at the Ottawa Carleton Detention Centre, makes clear his current reliance on a network of volunteers and professional visitors. ${ }^{312}$ Veteran Ottawa area prison chaplain, Father Victor Skilandziunas, who coordinated Prison Pastoral Services for three institutions (Ottawa Carleton Detention Centre, Rideau Correctional Centre, Burrit's Rapids, Ont., and Perth Jail) from 1972 to 1984 , had organized approximately 150 volunteers of different faiths that would come into the correctional facility on a regular basis. ${ }^{313}$ Clearly, then, prison chaplains provide a link between incarcerated offenders and members of the community, thus facilitating a spirit of reconciliation between offenders and the community affected persons.

Clearly, prison chaplains are demonstrated to interface with various affected persons in addition to the inmate. However, an observation that is apt is that there is no systematic pattern consistent for all chaplains for such interfacing. Much appears contingent on the nature of each individual context, such as the structure of the chaplaincy program, the particular workload and other constraints on the chaplain, the security classification of the institution and so forth. The examples cited above therefore point to individual facets of particular contexts that are consistent with the principle under consideration, but also to a potential that could be further developed across the board, perhaps through information sharing and a delimitation of best practices principles for affected person's engagement.

\footnotetext{
${ }^{311}$ James, J.T.L., 1990 at 200.

${ }^{312}$ Wake, C., interview with the author, Ottawa, ON, April 26, 2005.

${ }^{313}$ Bradley, J. W., letter to Rev. Br. Justin Howson (April 10, 1982) in Behind the Prison Walls (Part One), Ottawa, 1997.
} 
Chaplains' effect on the broader community

There is another dimension to the prison chaplains' interaction with the community: an effect that may be described as a healing reverberation back into the community that volunteer and other community-related activities have. To explain, by taking part in prison chaplaincy programs, members of the community interact with offenders and other members of the corrections environment. In this way, a major barrier separating the incarcerated from society is penetrated, if not partly broken down. The humanity of prisoners is thus restored in the eyes of the volunteers, who then find it easier to identify with their plight and in this way develop a sense of compassion for them that they carry with them and even witness to outside of the prison. The effect may be described as healing and even restorative that exists on a broader, social level, thereby rendering the post-incarceration environment more hospitable.

It is possible to draw upon the vast experience of Fr. Skilandziunas for a specific example of this dynamic. During his ministry (1972 to 1984), Skilandziunas organized two groups of college and high school student musicians that would meet almost every week to rehearse for their weekly (Sunday) visits to the prison, during which they would perform at Masses held for the prisoners. ${ }^{314}$ Through the facilitation of the prison chaplain, students were brought into direct contact with prisoners, worshiping and socializing with them. These encounters broke down prejudices and stereotypes, and the effect spilled over outside of the prison as these students returned to the community with their new impressions of the prison environment and those who are incarcerated in it.

\footnotetext{
${ }^{314}$ Skilandziunas, V., "Letter of recommendation and nomination of Sister Elisabeth Ann Kinsella and Mr. James P. Teehan for Community Service Award," in Behind the Prison Walls (Part 1), Ottawa: 1997.
} 
There are other ways in which prison chaplains have an impact on the community. Perhaps in large part due to the draw of volunteers, prison chaplains sometimes gain positive media attention for their work. Numerous articles about the work of Fr.

Skilandziunas have appeared in the mainstream Canadian press, as well as the newspapers and other periodicals of the Lithuanian Community of North America, of which Fr. Skilandziunas is a part. ${ }^{315}$

Also, because of the chaplain's position within his or her respective faith community, he/she potentially has linkages with various segments of the broader community, including community leaders. For instance, Rev. Carl Wake discusses how his service to the community at large is in the form of information about prison and his work in the prison. ${ }^{316} \mathrm{He}$ is often approached by various churches that ask how they can become involved in the prison ministry and he visits them and gives talks. ${ }^{317} \mathrm{He}$ also arranges placements for interested college and university students. ${ }^{318}$ In these ways, he exposes the otherwise hidden prison environment to the community writ large and, in doing so, opens up the possibility for a sort of nascent mutual understanding and healing that clearly shares a likeness with restorative justice.

Fr. Skilandziunas is also known to have attracted interest from various segments of the community. Perhaps most notable were the interest and attention of the

\footnotetext{
${ }^{315}$ See for instance, Rūta Ona Šiūlytè, "Lietuvis kunigas tarp žmogžudžių" [Lithuanian priest among murderers], Ateitis (October 10, 1982) at 345-347; B.P. Kleinotas, "Pasikalbèjimas su kaléjimo kapelionu" [Conversation with a prison chaplain], Mūsu žinios vol. 5, no. 225 (May 22, 1987), at 90-91; K.J. Ambrasas, "Labiausiai paveikus yra pavyzdys" [Most effective is an example], Tèviškès Žiburiai (January 23, 1996); K. J. Ambrasas, "Lietuviu pèdsakai Kanadoje" [Lithuanian footprints in Canada], Draugas (December 9, 1995) at 4; Ghulam Nanji "Faith in God not forgone at local detention centre," Ottawa Journal (April 26, 1980); Peter Rabb, "Prison chaplain's life has rewards," Ottawa Journal, (June 24, 1978) at 40; "A welcome recidivist," Correctional Update, vol. 11, no. 1 (March/April 1983); R. G. MacNeil, "Ex-prisoners and the church: Is enough being done?", The Citizen (July 23, 1983) at 13; "Des meurtriers, des voleurs et des...", Le Droit (April 6, 1974) at 14.

${ }^{316}$ Wake, C., interview with the author, Ottawa, ON, April 26, 2005.

${ }^{317}$ Ibid.

${ }^{318}$ Ibid.
} 
Archbishop of the Ottawa Diocese, J.A Plourde and the Papal Nuncio (Pope's

representative) in Ottawa, Archbishop Angelo Palmas. The Ottawa Archbishop's interest

is clearly articulated in a letter to Fr. Skilandziunas, accepting his invitation celebrate

Mass at one of the correctional facilities:

Thank you for your excellent report on the Prison pastoral services during the year 1976. I read it with interest and renew my congratulations on the fine work being done by you and your associates. I will be delighted to preside at the special Christmas Folk Mass at Burritt Rapids at 2 P.M., on Sunday, December $18^{\text {th }}$. Similar celebrations in the past are among my most pleasant memories. ${ }^{319}$

The letter clearly demonstrates how a prison chaplain's links with community leaders

helps to attract their attention quite directly to the prison environment by even facilitating their presence among the prisoners. The same tendency is illustrated in a letter from the

Papal Nuncio following his visit to one of the correctional facilities:

After my visit to the "Rideau Correctional Center", I want to thank you warmly for taking the initiative of inviting the representative of the Holy Father to have an encounter with that community of friends whose qualities of mind and kindness I was allowed to appreciate. It was for me a very enriching experience, and its souvenir will always kindle my soul. ${ }^{320}$

That these words reflect a sincere interest and appreciation is further illustrated by a

subsequent letter, in which the Papal Nuncio writes:

I am writing to ask of you a kind favour. The Inspector of Chaplains for jails and houses of correction in Italy wants information about the position and work of the ministers of the cult in the prisons in Canada. This information is meant for a forthcoming study on the pastoral work to the mentioned institutions. ${ }^{321}$

\footnotetext{
${ }^{319}$ Plourde J. A., (Archbishop of Ottawa), Letter to Fr. Victor Skilandziunas, October 24, 1977, in Victor Skilandziunas, Behind the Prison Walls (Part I), Ottawa, 1997.

${ }^{320}$ Palmas, A., (Archbishop), Letter to Fr. Victor Skilandziunas, March 19, 1979, in Victor Skilandziunas, Behind the Prison Walls (Part I), Ottawa, 1997.

${ }^{321}$ Palmas, A., (Archbishop), Letter to Fr. Victor Skilandziunas, February 29, 1980, in Victor

Skilandziunas, Behind the Prison Walls (Part I), Ottawa, 1997.
} 
That officials from such a prominent civil society organization ${ }^{322}$ as the Roman Catholic Church in Ottawa took sincere notice of Fr. Skilandziunas's work is significant in terms of restorative justice because it demonstrates the bridging function that prison chaplains can play between prisoners and the society from which they are segregated. In addition, such bridging produces a positive reverberation within the community by fostering a better understanding of the condition of prisoners, as well as shedding light on their humanity.

The fact that prison chaplains, through their networks and their own standing in their respective faith communities, are able to impact the wider community makes them considerably well-placed to generate a broader societal context of healing, one in which the community-writ-large is not totally cut off from the plight of prisoners, understands them better and is potentially more accepting of them during their post-incarceration reintegration.

\section{$\underline{\text { Self-restoration }}$}

As mentioned earlier on, prison chaplains have an impact upon the prisoners that they minister to. The change that they help bring about often begins with self-restoration,

\footnotetext{
${ }^{322}$ Religious/church groups are commonly considered to be "civil society organizations." See for instance "Frequently Asked Questions," in Civil Society (Organization of American States), http://www.civilsociety.oas.org/Pages/FAQ_ENG.htm; "Civil Society Organizations," Developing Ideas Digest (January, 1998), http://www.iisd.org/didigest/jan98/2jan98.html; "Gender Equality and Peacebuilding: Lessons Learned," Canadian International Development Agency, July 3, 2000, http://www.acdicida.gc.ca/cida_ind.nsf/0/5c6765165f390eb585256a87000f6763?OpenDocument; "Examples of Government-Civil Society-World Bank Collaboration," The World Bank Group (2005) http://web.worldbank.org/WBSITE/EXTERNAL/TOPICS/CSO/0,,contentMDK:20138127 pagePK:22050 3 piPK:220476 theSitePK:228717,00.html; and "Secretary General's Message at the Civil Society Forum," United Nations, Sao Paulo, June 2004, http://www.un.org/apps/sg/sgstats.asp?nid=977.
} 
which can be defined as the regaining of a minimum of self-respect and self-validation. ${ }^{323}$ Odillo Guidoni in his article explains that for this to take place, the offender "needs to reconstruct his life path and in particular his moral career, that is, self-image and selfconception." ${ }^{\text {324 }}$ Paul Skanks, Traditional Mohawk Nation Teacher, provides a definition for self-restoration by saying that "it is something that has existed in its form, it has been covered up or maybe even obliterated and one needs to peel that back to come to the way it was." 325 Moreover, Guidoni continues "any process of assuming responsibility for one's acts is also a process of reconstruction of the self, of one's identity, so that the person can say what he is compared to what he was." ${ }^{326}$ Therefore, prison chaplains' help prisoners see themselves differently, separating themselves from their actions and coming to the understanding that it is possible to repent, to correct mistakes that have been made and to strive for better self. Chaplaincy volunteers at the Ottawa Carleton Detention Centre, Sandra Stott and Bev Moorhead explain the premise for self-restoration by drawing attention to the fact that prisoners are often victims themselves:

They have been victims of sexual abuse, abandonment, rejection, physical abuse. So in some respects, with every inmate that we deal with, we are dealing with a victim themselves, plus they have become victimizers out of their own hurt. ${ }^{327}$

Also Stuart Schroeder, from Ontario Multifaith Council concurs by saying that:

Prisoners are people, they are normally scared, hurt, badly abused and products of our own social systems. ${ }^{328}$

\footnotetext{
${ }^{323}$ Bastiansen, R., and Vercruysse, J., "Review of Restorative Justice in Belgium Prisons: Commentary on responding to the crisis," Prison Service Journal, no. 140 (March 2002) at 20.

${ }^{324}$ Guidoni, V. O., "The Ambivalence of Restorative Justice: Some Reflections on an Italian Prison Project," Contemporary Justice Review, 2003, Vol. 6, no.1 at 62.

${ }^{325}$ Skanks, P., interview with the author, Ottawa, ON, September 12, 2006.

${ }^{326}$ Ibid

${ }^{327}$ Stott, S., and Moorhead, B., interview with the authors, Almont, ON, September 15, 2005.

${ }^{328}$ Schroeder, S., interview with the author, Scarborough, ON, April 4, 2005.
} 
This links profoundly with restorative justice because it supports one of the main tenets of restorative justice, that is, that offenders themselves have been harmed at some point, if not earlier in their lives then certainly as a consequence of the offence that they themselves committed. This harm, along with those experienced by the victim and other affected persons within the immediate social network and broader community, needs to be repaired for restorative justice to succeed. From the point of view of the prisoner, selfrestoration really is the first step in the process. As Michael Skaljin - a prison chaplain of the Buddhist faith and Manager of the re-integration program at the Ontario Multifaith Council in Toronto - explains, the self-restoration of prisoners is a very important concern of prison chaplains:

That's really the key that has to happen before the rest can happen. [...] the person needs to change about how they see themselves because a lot of them have very negative images or ideas about themselves and a lot is because of their conditioning. They usually have been told that they are bad people. [...] in order for a person's self-restoration to happen, they need to start to see themselves as separate from their actions [...] that there is an innocent person within them, that their actions have been negative, [but] they need not see themselves as bad, but the actions [as such]. So we help them with their self-restoration. ${ }^{329}$

Likewise, Father Victor Skilandziunas affirms self-restoration as a priority concern for prison chaplains:

Yes, that is very important. Important for them to know that change is possible. That it is possible to become better, because many prisoners thought they could not do so anymore. ${ }^{330}$

Part and parcel of this is a sense of awareness that prison chaplains try to foster.

According to Skilandziunas, that means

an expanded consciousness, not only of oneself, but of others, which, as it develops, grows into a sense of unity with all these other human beings, so that selfishness, self-importance and self-interest are no longer first considerations. ${ }^{331}$

\footnotetext{
${ }^{329}$ Skaljin, interview with the author, Ottawa, ON, June 26, 2005.

${ }^{330}$ Skilandziunas, interview with the author, Ottawa, ON, November, 2003.
} 
Thus, in helping meet the moral and spiritual needs of prisoners, a main part of the chaplain's task is to help them "regain their sense of dignity, self-esteem and freedom to make their own decisions" ${ }^{\prime 332}$ and to convince them that they have not been rejected by their faith. ${ }^{333}$ A chaplain should be a presence that leads people behind bars to understand that they are "greater than their worst crime" and that "there is [in them] a spark of the divine that can be found and ignited; so there could be a transformation., ${ }^{334}$ This is self-restoration.

That this essential goal of prison chaplains is achieved in reality is evident in the testimonies of prisoners themselves. In a letter to fellow convicts, a former hardened criminal tells the story of his conversion. The major turning point for this man was when he was led towards self-restoration:

Father Victor, the Padre at the jail, came to see me in the hole and brought me a bible. He told me that Jesus Christ loves me and that he loves me. As a child I didn't get much love or attention, lots of punishment and beatings, but love is I guess what I really needed. ${ }^{335}$

Letters of other prisoners bear similar witness. One man writing to thank the prison chaplain for helping him find God reveals the self-restoration that he underwent: "I can tell you I have accepted the Lord into my heart and I've never felt more at peace with myself and the people around me." ${ }^{336}$ Another man compares the initial experience of his incarceration to a great darkening that was lifted by the prison chaplain, resulting in this man's self-restoration:

\footnotetext{
${ }^{331}$ Skilandziunas, interview with the author, Ottawa, ON, Novemeber 2003.

332 Skilandziunas, 1997 at 2.

${ }^{333}$ Rabb, P., "Prison chaplain's life has rewards," Ottawa Journal (June 24, 1978) at 40.

${ }^{334}$ Allard, interview by the author, Ottawa, ON, April 8, 2005.

335 Skilandziunas, (2003) at 39.

${ }^{336}$ Ibid. at 54.
} 
It was like the almighty light of God's first creation, the sun, obscured by big, dark clouds [...] that my burden of guilt and shame dawned upon me like a rainy day, I mean raining in my heart and soul and mind in the holding cell at reception. Well that's gone now, thanks to you and the Salvation Army. ${ }^{337}$

Likewise, the chaplain's success in leading the prisoner to self-restoration is evident in the following statement from a prisoner's letter:

It has been a great privilege for me and I think you will whole-heartedly agree with me. I am able to go to sleep at night without any regrets of the tomorrow in what it may bring. I can wake up in the morning with a "Thank you Jesus." [...] I really enjoy living, life has a meaning, life has become real and I surely want to share it with you and whoever you share these letters with. ${ }^{338}$

Another example from a prisoner's letter provides further evidence:

Hi. In case you don't remember me, I'm the one with Cancer, Aids, Hep C and that tumour on my neck. Ok, if that doesn't ring a bell, I'm the proud Irishman with tattoos who used to hate and dislike Protestants. Anyways both of you ladies impacted my life in each your own way. I have thought about our meeting often and prayers said within that day. It really was the Holly Spirit that day. I know that now. Not to mention the beautiful song played for me which to this day echoes. While this Irishman is still doing time I 'Thank you' for your compassion, caring and concern. I've gotten a lot of insight from both of you and I'm so glad I've gotten a chance to meet you. You thought this Irishman a valuable lesson 'God cares!' For now forgiveness is what I'm working on and trying to read God's word a little more each day. I shall bid you my ladies a fair well from Irishman who renounce Hell! ${ }^{339}$

From all of this evidence, it is clear that prison chaplains not only strive to lead inmates to self-restoration, they actually succeed in doing so. Even though, the concept of selfrestoration is not very prevalent in much of the literature on restorative justice, I argue that it is a key ingredient for the fuller sense of restoration that restorative justice seeks to bring about. Likewise, as Michael Skaljin (a prison chaplain of the Buddhist faith and Manager of the re-integration program at the Ontario Multifaith Council in Toronto)

\footnotetext{
${ }^{337}$ Ibid. at 55 .

${ }^{338}$ Ibid. at 98 .

${ }^{339}$ Prisoner's letter was provided by volunteers Stott, S., and Moorhead, B. This prisoner died two weeks after writing this letter. Spring 2006.
} 
affirms, it is a prerequisite for restorative justice in the prison setting. That prison chaplains succeed in this aspect gives credence to the argument that they are significant agents for restorative justice.

Whether "finding God", "Creator" or experiencing some other religious conversion is an actual prerequisite for self-restoration and thereby a prerequisite for restorative justice in prison, is up for debate. Can self-restoration occur without attending to the prisoner's spiritual dimension? Perhaps. It is likely that positivists and humanists would argue that self-restoration is a purely psychological phenomenon and the effect can be brought about by solely psychological means. It is not my purpose here to test such a hypothesis and I therefore neither accept nor reject its validity, however I do not discount the possibility out of hand either. One thing, though, that I can claim with certainty, based on the evidence assembled above, is that spiritual conversion experiences are certainly conducive to the self-restoration of inmates and herein prison chaplains often play a crucial role.

It is also worth considering whether the spiritual conversions that take place in the prison setting are truly authentic. That is because these experiences are often viewed sceptically and are pejoratively labelled "jailhouse religion," which is taken to mean a "false, temporary faith," often at great consternation to the inmates who are trying to change their ways. ${ }^{340}$ As others have put it, "“[j]ailhouse religion' typically invites an incredulous response from a sceptical general public."341 This tendency stems from a notion that "prisoners are inherently manipulative" and that "prisoners convert to religion

\footnotetext{
${ }^{340}$ Dominiquez, C., Interview by Scott Schaffer, "I never achieved chocolate status': Conversations with a reformed convict," Journal of Mundane Behavior, vol. 1, no. 3 (October, 2000), http://mundanebehavior.org/issues/v1n3/dominguez.htm.

${ }^{341}$ Curran, L. K., and Mitchell, W. E., "Abstract" in Born-Again? The Meaning and Significance of Religious Rebirth in Prison, 1999, http://www.asc41.com/www/1999/abscr094.htm.
} 
as a way to get out of prison" or to get lighter sentences. ${ }^{342}$ However, along with such insincere expressions of newfound religious faith, authentic "jailhouse conversions" do occur. ${ }^{343}$ In fact, there are ways of testing the sincerity of prison conversions, for instance by observing if they endure past an upcoming parole hearing, regardless of its outcome. ${ }^{344}$ That said, a reliable set of statistics demonstrating a probable ratio of sincere to insincere conversions is not available and has probably not been compiled.

Nonetheless, there is evidence that a significant proportion of prison conversions are authentic ${ }^{345}$ as well as meaningful "identity-transforming experience[s]."346

Transforming the conflict: from breaking rules to causing harm

As stated previously, one of the main aims of restorative justice is to transform the way that the offender looks at his/her particular offence, that is, to see it not in terms of breaking rules but as a harm done to one or more individuals and perhaps the community. There is no doubt that prison chaplaincy has traditionally shared this same aim, perhaps throwing into the mix the understanding of wilful harm as a transgression against God. Evidence to substantiate this claim abounds.

\footnotetext{
${ }^{342}$ Lozoff, B., and Maull, F., "Nation Behind Bars," Prison Dharma vol. 3, no. 1 (Spring 2001) http://www.prisondharmanetwork.org/pdf_nwltr/nwlterspring01.pdf, p. 4.; see also Harry R. Dammer, "Religion in Corrections," Encyclopedia of Crime and Punishment, vol. 3. at 1375-2002, http://academic.uofs.edu/faculty/DAMMERH2/ency-religion.html.

${ }^{343}$ Miller, D. P., "Ten Questions for Validating Spiritual Paths, Groups, and Teachers: Part I," Peaceful Paths, http://www.peacefulpaths.com/cgi-

bin/Web_store/web_store.cgi?page=sens0501.htm\&cart_id=95214.3381.

344 Ibid.

${ }^{345}$ Adullam House Newsletter (Queensland: Adullam House Fellowship Inc., September 2001), http://netministries.org/see/charmin/CM04371?frame=N; C. Robert Allred, "Forgiving Again, Again," Sermon Archive December, 1999, http://bobssermons.com/sermons/archive/990912.html; Robert L. Maginnis, "Faith-Based Prison Programs Cut Costs and Recidivism," Family Research Council, http://www.heartland.org/pdf/13134a.pdf.

346 "Recent Research Bolsters Case for Addressing Spiritual Needs of Prisoners," Inside Out, December 2003 , at 7 .
} 
Michael Skaljin, provides striking evidence of such transformation of conflicts as

a priority aim for prison chaplains. According to him,

[...] that's where the transformation really happens for a person mentally and emotionally, $[\ldots]$ when they see that their actions are harmful to people and are causing negative consequences or suffering for other people. That's when transformation can really happen and that's really the role of a chaplain. It's to talk with the person about the real effects that [the harm] is having on others. And not that they have broken some kind of rules of society and that is why they've been put into jail. That won't have any effect. [...] Where it affects us more is when we actually see that we have a negative impact on other people, that affects us more strongly to change our ways and to not do it again. ${ }^{347}$

The same sentiments resonate in Carl Wake's (Coordinating Chaplain at the

Ottawa Detention Centre) discussion of his approach to pastoral care:

When I work with inmates, I encourage them to think about the victim, think about their relationships and what it [the offence] does to their loved ones, to the victims. There are primary victims - the person you beat up or that you robbed and the secondary victims - your family, that is, your family worrying about you being in prison. ${ }^{348}$

There are concrete examples of this sort of transformation brought about through

prison chaplaincy. In an interview, prison chaplaincy volunteers (Ottawa Carleton

Detention Centre), Sandra Stott and Bev Moorhead, discussed one case where an

Aboriginal man, in prison for murder, spoke of his transgressions not as breaking the law, but in terms of the hurt that he caused real people. According to Ms. Stott,

in that particular case, he is a man that did not have a great upbringing and he was into sort of a criminal life-style. So for him to have recognition that he actually harmed people as opposed to just doing a criminal act was huge. ${ }^{349}$

Prison chaplains also play an important role as experts in, and ministers of, their particular faith traditions in seeing people through this transformative process by relating it to the central tenets of their faith and providing guidance in that regard. According to

\footnotetext{
${ }^{347}$ Skaljin, interview with the author, Ottawa, ON, June 26, 2005.

${ }^{348}$ Wake, interview with the author, Ottawa, ON, April 26, 2005.

${ }^{349}$ Stott and Moorhead, interview with the authors, Almont, ON, September 15, 2005.
} 
Scott Harris (Director, Restorative Justice and Dispute Resolution Division, CSC), it is often the case that

when people start to look at their crimes particularly, or their victimization, deeply from a restorative point of view, at some point they will hit a faith crisis of some kind. $[\ldots]$ chaplaincy and the role of chaplains is fairly central to being there and to accompany them through that crisis. ${ }^{350}$

So prison chaplains not only help offenders understand their offence as harm done to people, they also support them through a potentially stressful period that typically accompanies this recognition. They are in effect brokers of this crucial element of restorative justice and in this respect may be deemed significant agents of restorative change. Naturally, this observation needs to be framed within the recognition that it applies to those cases in which the prisoner is receptive to the chaplain's messaging. As discussed previously, participation in chaplaincy programs and one-on-one encounters is voluntary. Not all inmates choose to participate. Of those that do, there are a proportion of inmates that are either non-receptive or insincere. Nevertheless, this qualification does not refute the evidence that illustrates this transformative function of prison chaplains.

\section{A sense of remorse}

Another transformative aspect of restorative justice is the concept of remorse. Remorse for wrongs committed, that is, for harm done, is one of the crucial elements in any process of restoration. It should flow naturally from the acceptance of personal responsibility for the infliction of harm. In their pastoral and counselling roles, prison chaplains are well placed to guide offenders beyond the recognition of the harm that was caused and to this point of empathy for the harmed individual(s).

${ }^{350}$ Harris, interview with the author, Ottawa, ON, April 11, 2005. 
One dramatic example of an inmate experiencing remorse for past wrong-doing is documented by Father Skilandziunas (retired chaplain):

Once a young woman approached me telling me that she would like to make a confession. I said OK. When we sat down, she told me that it is very hard for her to express her feelings verbally, but that she has written down everything on three pieces of paper. Just imagine! She continued to say "if you don't mind, could you please read my confession, Father Victor, and then it is up to you what you want to do with it." When I read the confession, it moved me. Everything was written straight from the heart, very honest. She had put down all of the pain that she had suffered, all the bad things that she has done in her life - in those three pages. While I was reading, I smiled at one point and she became so happy. I told her that this is perfect, there can never be a better confession, even verbally it is hard to express oneself the way she did on paper. I gave her absolution and she was truly happy. ${ }^{351}$

This particular example is directly significant to the discussion of restorative justice. It illustrates how prison chaplains enable the expression of remorse (an important step from a restorative justice perspective) by providing an ear, by listening. It is also illustrative of their capacity to help the offender move forward from dwelling on that remorse by attaining reconciliation on a spiritual level, in this particular case by hearing the offender's confession and granting absolution (the approach varies from faith tradition to faith tradition).

Though remorse is a feeling and thus sometimes difficult to observe in and of itself, it also finds expression in the form of denunciation of one's own unacceptable behaviour and genuine concern for the wronged party. In Chapter 3, denouncing one's own unacceptable behaviour was listed as one of the goals of restorative justice. There is evidence of offenders denouncing their transgressions as a product of the pastoral guidance of prison chaplains. For example, in a letter to fellow inmates, a prisoner

${ }^{351}$ Skilandziunas, interview with the author, Ottawa, ON, November, 2003. 
expresses his remorse for past mistakes by denouncing them and attributing his changed

frame of mind to the prison chaplain who guided him:

I'm far from great, probably worse than a lot of people you know, but now I'm leaving here with a peace of mind [...] If any of you inmates know me from the Ottawa Jail you'll remember what I was like. If I wasn't starting a riot I was fighting with 2 or 3 guards. I spent almost a year at the Ottawa Jail on bean cake in the hole there and another year in population between maximum and minimum and the male seg. (I was so naughty one night they made me sleep in the visiting room.) But that makes me think of how much a fool I was. I had money; I had fast cars and fast women. Where did it get me? Millhaven, of all places. I don't know how to ever thank Father Victor for turning me to Christ. ${ }^{352}$

Sandra Stott describes a similar transformation of an inmate who had typically been considered a hard case:

He is a person that we had seen in prison when we first started going into prison, and he was with OCDC and then he got moved. [...] He did not have a lot of remorse, he was questioning a lot of things, he ended up being a cell mate of somebody else we ministered to and through [exposure to] that process came to understand the error of his ways and then wrote after he left the OCDC [...] And he had at that point in time given his life to Jesus, and it was all through the work of the Holy Spirit; he was feeling the presence of the Holy Spirit. We were not actually saying [to him] "you did wrong." He recognized his wrongs through that conviction and was very, very remorseful and wanted freedom from his dark past. He denounced his bad behaviour. ${ }^{353}$

Denouncing one's own wrongful behaviour is not only consistent with restorative justice, but it is deemed one of its goals and is a logical prerequisite for the offender's wilful participation in the reparation of harms.

Likewise, it is not uncommon for those offenders who have responded to the pastoral care of prison chaplains to exhibit genuine concern for the victim. That is because the approach of chaplains is to be non-judgemental, open and to build a trusting relationship. This is something that many inmates have never really had in their lives.

\footnotetext{
${ }^{352}$ Skilandziunas, Behind the Prison Walls (2003) at 44.

${ }^{353}$ Stott and Moorhead, interview with the authors, Almont, ON, September 15, 2005.
} 
By providing this, chaplains can help lead inmates to experience an authentic regret for some of their actions, recreating the approaches of Jesus and Buddha. ${ }^{354}$

A specific case illustrating this effect is that of an inmate who committed a serious assault while in prison, but prior to experiencing the full effects of pastoral care. Through the influence of the chaplain, the inmate came to the realization that he had harmed another person by his actions and wrote in a letter to the chaplain: "I deeply regret what unfortunately happened to Mr. Lennon. [...] Please visit Mr. Lennon and say I regret what happened and wish him a speedy recovery. ${ }^{, 355}$ His expression of remorse came about through his own initiative, perhaps after some reflection and contemplation, in the form of a letter. The sincerity and authenticity of the remorse are evident. Whether or not it was his interaction with the chaplain that impelled him to feel remorse for his wrongs, it is clear from the letter that he felt that he could look to the chaplain as someone with whom he could share and make sense of this experience.

There are some chaplaincy programs that are specifically geared towards these ends, that is, towards helping inmates explore the effects of the harms that they have caused and to identify with the victims of those harms. There is one program called "Making Wrongs Right," where inmates are invited to think of a few people whom they have harmed and are encouraged to write letters of apology to them. ${ }^{356}$ These letters are not always sent out to the addressees. Nonetheless, there is much therapeutic value ${ }^{357}$ in

\footnotetext{
${ }^{354}$ Skaljin, interview with the author, Ottawa, ON, June 26, 2005.

${ }^{355}$ Skilandziunas, Behind the Prison Walls (Vilnius: Vilnius University Publishing House, 2003) at 52-53.

${ }^{356}$ Skaljin, interview with the author, Ottawa, ON, June 26, 2005.

${ }^{357}$ Letter writing as a therapeutic technique can help one face his/her problems in a deeper way. It can be a way to relieve stress as it allows one to expand on specific thoughts and feelings. Writing about emotional upheavals has been shown to enhance the mental and physical health of prisoners. For a description of the therapeutic aspects of this and other types of expressive writing, see Haifa Al Sanousi, The Psychological Role of Expressive and Literary Writing - A Case Study on Kuwaiti Women" PSYART, article 040706 (2004), http://www.clas.ufl.edu/ipsa/journal/articles/psyart/2004_sanousi01.shtml.
} 
the process itself, which causes the inmates to reflect on what they did to real people and how they might go about owning up to their role in causing the harm and asking for forgiveness.

As these examples clearly demonstrate, prison chaplaincy does foster the psychological strides that lead offenders to experience a true sense of remorse (again the same caveats concerning level of participation and sincerity of the participants apply). Given that this is also a crucial element of restorative justice, especially from the point of view of the offender, prison chaplains are in this regard a significant driving force.

There are potential risks, however, to the "reparative possibilities"358 of remorse. First, the affected persons coming in to the face-to-face meeting may automatically suppose that the offender is genuinely remorseful. ${ }^{359}$ When victims do not receive an acknowledgement from an offender for committed crime, does not apologize, does not show any signs of remorse, it is likely to be painful to victim. ${ }^{360}$ For example this is a brief example of Deborah Eappen's story, "whose eight month son Mathew was allegedly murdered by his caretaker, Louise Woodward:

Deborah: She (Louise) doesn't seem to have a conscience. She has lied so much, she probably even believes what she's saying. It is incredible.

Terry: Would your feelings about Louise be different if she had apologized after Mathew died?

Deborah: The fact that she showed no remorse is very offensive."361

Such unsuccessful encounters between affected persons and an offender run the risk of revictimization. Also, with sexual offences the offender may manipulate the situation placing the blame on the victim, the offender may verbally cause harm, thus reinforcing

\footnotetext{
${ }^{358}$ Presser, L., "Remorse and Neutralization Among Violent Male Offenders," Justice Quarterly, Vol. 20 No. 4 (December 2003) at 804.

${ }^{359}$ Ibid.

${ }^{300}$ Ibid.

${ }^{361}$ Ibid.
} 
abusive behaviour $^{362}$ and instead of victim's feelings to be restored to actual extent possible, the feelings of anger, shame, guilt and hurt may surface again. I will reiterate Daly's point that the hope of the affected persons and offender to reconcile is just a hope, reconciliation is not to be expected. ${ }^{363}$

Second potential risk to the "reparative possibilities"364 of remorse is by what rules do prison chaplains' measure offender's genuine remorse for the crime committed? How do they know when offender is sincere rather just manipulating the situation and feelings? Paul Skanks, Mohawk Traditional Teacher also points out that it is difficult to know exactly whether a person is remorseful for his/her wrongdoing ", [it] is one of the difficulties because there are people who are playing the lip-service." 365 According to Ross London, “while we may never know the offender's real intent, the very act of offering an apology by one who was previously a 'victimizer' - even if it is performed in the hope of gaining lenient treatment - is inherently empowering to the victim, since it is the victim who has the authority to evaluate the sincerity of the offender and to accept or reject the offer of apology." 366

\section{A sense of obligation}

Quite central to the restorative perspective is the notion that offenders need to develop a sense of obligation towards the wronged parties. This follows quite naturally from a sense of remorse. Often times, though, guidance through this transformative process is

\footnotetext{
${ }^{362}$ Daly, "Restorative Justice and Sexual Assault," British Journal of Criminology, 2006 at 337.

${ }^{363}$ Ibid at 336.

${ }^{364}$ Presser at 804.

${ }^{365}$ Skanks, E. P., interview with the author, Ottawa, ON, September 12, 2006.

${ }^{366}$ London, D. R., "The Restoration of Trust: Bringing Restorative Justice Reform from the Margins to the Mainstream," (Criminal Justice Studies, Vol.16, No. 3) at 183.
} 
beneficial. The prison chaplain can often play a useful role by guiding the offender to take personal responsibility for the harm and to help him/her to "map a restorative way forward."

Michael Skaljin explains how he and his organization help inmates plan out how they can meet with family members in order to seek forgiveness and make amends. ${ }^{367}$ It is usually the lingering pain of a hurt that forms an obstacle to the restoration of the inmate with his/her family. In Skaljin's words, "we kind of help that family restoration happen [through] dialogue and a controlled situation and so eventually the family will welcome that person back and maybe will even give them a place to stay." 368 However, in order for the family, for the community to welcome offender back, Skanks explains that offender has to earn his/her way back. The person has to demonstrate it: "if part of your problem is alcohol and drugs, then you have to clean that up. If your problem is some petty theft or whatever, then you have to demonstrate it again that you are not going to do that but that you are going to restore." 369

\section{Righting the wrongs: facilitating meaningful reparations}

The offender's ability to make meaningful reparations can go a long way towards overall restoration, as demonstrated in the Elmira case that is often cited as the first contemporary case of restorative justice. On occasion, the prison chaplain may play a facilitating role for the making of reparations. As discussed above, the same program that Michael Skaljin runs is involved in facilitating meaningful reparations by helping

\footnotetext{
${ }^{367}$ Skanks, E. P., interview with the author, Ottawa, ON, September 12, 2006.

368 Ibid.

${ }^{369}$ Ibid.
} 
inmates write letters of apology, which are sometimes sent out to their addressees. In addition to the therapeutic effect of this sort of letter-writing, the letters (when actually sent out) help restore the lines of communication between the offender, the victim(s) and/or the offender's immediate network of social support. One of the potential effects of such chaplaincy programs is the partial restoration of damaged relationships, or at least the beginning of a dialogue that is conducive to such a restoration.

\section{Righting the wrongs: restoring social network}

One of the key aims of restorative justice is to restore the social network that was damaged as a result of an offence. There are some striking instances of the restoration of inmates' social networks, resulting from the growth that takes place under the chaplain's guidance and pastoral care. In one example, an inmate writes about his reconciliation with his mother:

I just used to write my mom hate letters and she would write back and make light of me being the same old Ken and she would tell me that she loved me. When I met [Jesus], I wrote my mom and told her I loved her. She came up to Ottawa to visit me to see if I had flipped my lid. ${ }^{370}$

In another example, an inmate relates her appreciation to the chaplain for his role in helping her reconcile with her husband:

You helped me in many ways, especially in my decision with Rick. I said, "Hi," to him for you, but it will be a while before I get a reply. I'm sure he was pleased. All in all, I hope that everything turns out for the best, as far as the family. We're going to work together on it. I hope that Rick is paying for his sins, that he will have God's and your blessing. I hope we can make it together as I will try my hardest to always give him my support. ${ }^{371}$

\footnotetext{
${ }^{370}$ Skilandziunas, 2003 at 50.

371 Ibid. at 56.
} 
While this example illustrates the point that prison chaplains can play a part in restoring the prisoner's social network, it also introduces the concept of sin. What is sin? How does it differ from crime? Both concepts are related and, given the subject of this thesis, deserve to be clarified. Without digressing too far into what could otherwise be a very lengthy discussion, I simply offer up my own understandings of these two words in their most basic form. "Sin" is a wilful transgression of God's will. "Crime" is a wilful transgression of the laws of the state. Key differences between sin and crime as I have just defined them are that the will of God is eternal and unchanging, whereas the laws of the state come about as a compromise between governments and those that they govern, and are therefore changeable and contingent on time and place. Again, based on my understanding, the overlap of sin and crime is not perfect. That is, not everything that is permitted by God is necessarily permitted by the state. Not everything permitted by the state is permitted by God. By logical extension, not everything forbidden by God is forbidden by the state and not everything forbidden by the state is forbidden by God. The relevance to this thesis is profound. A person is imprisoned for committing crime, that is, breaking the laws of the state. The approach of restorative justice is to re-cast the crime as harm done to people, that is, to put it in terms that are remarkably similar those of sin (most would agree that wilfully harming people constitutes a transgression of God's will). In helping inmates cope with sin and restore the social relationships that were damaged through sin, the prison chaplain is in effect doing restorative justice, only is coming at it from the other (spiritual) angle. 


\section{$\underline{\text { Similarities between approaches? }}$}

Restorative justice has gained much credence in prison chaplaincy circles. ${ }^{372}$ As mentioned, the imperative to adhere to restorative principles is presently enshrined in the Correctional Service of Canada Statement of Ethics for prison chaplains. Does prison chaplaincy bear resemblance in form to any of the major approaches of restorative justice? A case could be made that some aspects of prison chaplaincy can resemble, or at least can lead to events that resemble, some of the conferencing approaches of restorative justice. Michael Skaljin (a prison chaplain of the Buddhist faith and Manager of the reintegration program at the Ontario Multifaith Council in Toronto) makes the case that when the prison chaplain is able to bring people (affected persons) together, what transpires most resembles the conferencing model. ${ }^{373}$

That said, one should bear in mind that prison chaplaincy was created for the purpose of tending to spiritual needs over a period of time. It is multidimensional in its nature and does not centre around a one-off event like many of the predominant restorative justice approaches. And it fulfills a mandate that is much broader than the narrower (albeit nonetheless broad) aims of restorative justice. For this reason, restorative justice and prison chaplaincy are not interchangeable. Nonetheless, prison chaplaincy often generates events that bear resemblance to formal restorative justice approaches. Furthermore, Scott Harris, (Director of Restorative Justice and Dispute Resolution Division, CSC) makes the case that restorative justice is both a perspective (a way of looking at things, an understanding) and a process (a systematic way of doing

\footnotetext{
${ }^{372}$ See for instance the text of a 1985 sermon by Rev. Don Misener, reproduced in J.T.L James, 1990 at 204-207, in which he casts the Judeo-Christian concept of justice in clearly restorative terms, emphasizing the need to restore harmony to relationships over isolation and retribution.

${ }^{373}$ Skaljin, interview with the author, Ottawa, ON, June 26, 2005.
} 
something). ${ }^{374}$ It is likely that prison chaplaincy typically resembles more so the restorative justice perspective in that it bears many of the same principles and goals of restorative justice, but is not structured the same way around encounters involving multiple affected persons.

An interesting comparison between the form of restorative justice and that of prison chaplaincy can nonetheless be made by viewing the two from a slightly different perspective. That is, prison chaplaincy may be conceived in terms of a potentially significant means for laying the groundwork for successful restorative justice encounters. When considering how prison chaplaincy relates to restorative justice in terms of form, a useful analogy for its groundwork-laying function may be found in the literature of conflict analysis, specifically on the topic of "prenegotiation." Prenegotiation is an important element or phase of the overall process of negotiation, ${ }^{375}$ however it is the part that precedes actual negotiation, that is, when disputants actually sit down and talk. Essentially, prenegotiation is the "span of time and activity in which parties move from conflicting unilateral solutions for a mutual problem to a joint search for cooperative multilateral or joint solutions." 376 It is the laying of the groundwork necessary before actual negotiations can take place. But at the same time, it is much more than that. A lot is accomplished during prenegotiation, including lowering the risks of cooperation, an assessment of costs, establishment of an understanding of reciprocity for concessions, consolidating internal support for a shift to a conciliatory position, eliminating some of the alternative solutions, defining/selecting participants and building bridges. ${ }^{377}$ To avoid

\footnotetext{
${ }^{374}$ Harris, interview with the author, Ottawa, ON, April 11, 2005.

${ }^{375}$ Zartman, I. W., "Prenegotiation: phases and functions," International Journal, XLIV Spring 1989 at 238.

${ }^{376}$ Ibid. at 240 .

${ }^{377}$ Ibid. at $244-249$.
} 
straying off topic, I will not go into detail about all of these aspects of prenegotiation. The purpose is merely to describe something that most people intuitively know, even if they are not familiar with the term "prenegotiation" - that prior to formal negotiations, much is achieved in terms of laying the groundwork, working out problems and perhaps even achieving the goals of the intended negotiation.

Prison chaplaincy, in this sense, can be thought of as functioning as a sort of "prenegotiation" of restorative justice. In many ways, prison chaplaincy does much of the heavy lifting of restorative justice by laying the groundwork for the restoration of the inmate. As stated elsewhere, "[p]rison chaplains help prisoners develop a spiritual and moral framework that can further their individual efforts to reform their lives." 378 Often times, the success of prison chaplaincy goes beyond mere stage setting because of its significant restorative capability. Nonetheless, its main impact, as with prenegotiation, is upfront, as a momentous change that enables a desired outcome. For that reason, prison chaplaincy is not so much a standalone model for restorative justice as it is a significant implement, and its practitioners - significant agents. And in this sense, prison chaplaincy could be coupled with restorative justice initiatives, where prison chaplains may have additional latitude as agents of restoration.

\section{Formal participation of prison chaplains in restorative justice}

The fact that prison chaplains naturally play a significant role in restoration has not gone unnoticed. Perhaps it is for this reason that prison chaplains are increasingly involved in

\footnotetext{
378 "Prison Ministry - The Need Remains," Wisconsin Catholic Conference (February 25, 2002), http://www.wisconsincatholic.org/issuebrf/prison.htm.
} 
formal restorative justice in one form or another in prisons, ${ }^{379}$ adding even further credence to the thesis that prison chaplains are significant agents of restorative justice. In fact, there is reason to believe that the role of prison chaplains in restorative justice will be enhanced over time. ${ }^{380}$ In this section, this main argument is further strengthened by examining relevant aspects of the participation of prison chaplains in actual (formal) restorative justice initiatives and encounters.

\section{$\underline{\text { Unique position }}$}

In a very general, almost philosophical sense, prison chaplains are suited in a unique way to the process of restorative justice in that they are knowledgeable in the matters of the soul and are specialists in the spiritual aspects of restoration. Along with law enforcement officials, psychologists, social workers and other professionals, prison chaplains occupy a special niche that is no doubt relevant to this field and must be recognized. As Rev. Carl Wake explains,

I believe strongly in the holistic approach and human beings are not just body and mind. We meet the physical needs here: we provide food, clothing, shelter, water - the basic necessities. There are psychologists [...] if anyone is in real crisis, they get to see a psychologist. But there is a spiritual side to everyone [...] and the spiritual side has everything to do with how the body is running and how the mind is running. Body, mind and spirit are intertwined. [...] God created people with all of these needs: physical, mental, spiritual, psychological, social. People are trying to meet all their needs all the time, but they are not used to thinking about the spiritual side. [...] I believe strongly that these men and women, they haven't made the right decisions, they are not in contact with their spiritual side and if they were to honestly explore their relationship with God and start getting right with God, other things will just naturally fall into place. ${ }^{381}$

\footnotetext{
${ }^{379}$ Rabey, S., "Redeeming the Prisoners: Prison ministers embrace 'restorative justice' methods," Christianity Today (March 1, 1999) at 27.

${ }^{380}$ Harris, interview with the author, Ottawa, ON, April 11, 2005.

${ }^{381}$ Wake, interview with the author, Ottawa, ON, April 26, 2005.
} 
Wake's observation supports this notion that prison chaplains have a special niche in their service to the prison community. Furthermore, it should give pause to those policymakers who oversee corrections policy in an environment increasingly influenced by secular humanist trends, ${ }^{382}$ which function in opposition to the spiritual side of things, thus posing a risk to this important dimension of the restoration of inmates.

Wake's point of view is echoed by Harris, who makes the case that the prison chaplain, in helping an inmate understand the impact of a crime, discusses the consequences "on the spiritual level" including "what happens to a person with a consequence for them spiritually and what they need to do to respond to some of those crises in their own lives." 383 It is very difficult for people to "go through a restorative justice experience/journey without at least wrestling with questions of faith." 384 Restorative justice itself, at a very deep level, can be said to branch out of spirituality. ${ }^{385}$ A prison chaplain's participation in restorative justice thus helps ensure that the spiritual side of things is attended to during the process. An illustration of this from the Buddhist perspective is given by Skaljin:

For me as a Buddhist, one of the basic principles that helps is that we have the principle of interdependence. So, it's trying to help someone to understand that they are part of a larger system, that they don't live autonomously. [...] And for us it is to try to show that spiritual message that if we put out positive energy or helpful actions that those will come back to us and so we try to show to somebody that they need to move in that direction because that is a kind of universal law of

\footnotetext{
${ }^{382}$ Hadley, "Introduction: Multifaith Reflection on Criminal Justice," in Michael L. Hadley, ed., The Spiritual Roots of Restorative Justice (Albany: State University of New York Press, 2001) at 3-5. ${ }^{383}$ Harris, interview with the author, Ottawa, ON, April 11, 2005. 384 Ibid.

${ }^{385}$ Allard, interview with the author, Ottawa, ON, April 8, 2005; see also Wayne Northey, "Spirituality Evaluation of Restorative Justice, Sixth International Conference on Restorative Justice, "Best Practices in Restorative Justice", June 4, 2003, http://www.sfu.ca/cfrj/fulltext/northey2.pdf at 2, where he expands upon the argument of the Bible as spiritually the first and main source for the emerging phenomenon of Restorative Justice. Furthermore, Hadley (2001) affirms that restorative justice is "a deeply spiritual process," a "tough-minded journey that challenges the human spirit," whose "context and focus are unabashedly theological," at 9-11.
} 
cause and effect. So rather than a person getting angry about what they've got, we try to show them how they can create for themselves a positive situation by being nice to others, especially those whom they have harmed in the past. ${ }^{386}$

Furthermore, by attending to the spiritual side of the matters at hand, the chaplain helps bring participants into closer touch with the universal morality that is also at the core of restorative justice. In that way, he/she helps the inmate transcend the various man-made rules, and other limitations that impede his/her restoration, thereby leading to the achievement of a full sense of justice.

\section{Making restorative justice available to inmates}

In addition to their qualifications as spiritual guides, prison chaplains are in an institutional position to create opportunities for restorative justice encounters. It is safe to say that the majority of inmates had not been offered an opportunity to deal with their transgression in a restorative way at any point from their arrest to their incarceration. The whole notion of restorative justice is foreign to many. However, for those who undergo the sort of transformation catalyzed by prison chaplaincy, the yearning for restoration is not foreign. There are some situations where inmates are aware to some degree of the restorative justice approach and would like to try it. In each situation, it is possible for a prison chaplain to initiate a restorative justice conferencing event, if the prison allows for it. $^{387}$

It is in these circumstances that the service of the prison chaplain can be of great assistance. As Rev. Wake (Coordinated chaplain at the Ottawa Carleton Detention Centre) explains, inmates are sometimes referred to him for restorative justice

\footnotetext{
${ }^{386}$ Skaljin, interview with the author, Ottawa, ON, June 26, 2005.

387 Ibid.
} 
conferencing. ${ }^{388}$ In those instances, his role is to conduct pre-conference and postconference interviews. During these interviews, he asks the inmate if he/she would ever consider meeting with the victim sometime down the road (after release) in order to make peace with him or her. In doing so, he plants a seed in the victim's mind and sometimes, following a successful conference, the inmate actually requests to meet with the victim. Rev. Wake has a contact in the Collaborative Justice Project, an organization that works with people who are in conflict with the law and are interested in repairing the harm experienced by the victim. He refers such inmates to his contact, who meets with the inmate following his/her release and then facilitates a meeting between the inmate and his/her victim. ${ }^{389}$

Naturally, meetings between the offender and victim can only take place with the mutual consent of both parties. In circumstances where victims do not want to meet with the offender, the meeting simply does not take place. That does not necessarily close the door to restorative justice entirely. As has been demonstrated earlier in this chapter, prison chaplains are at times able to facilitate indirect encounters, such as communication by letter. There are other types of physical encounters, called victim impact panels that bring offenders together with a set of volunteer victims unconnected to the offence of the participating inmates. The victims explain to the gathered inmates how the crimes have affected them and in some cases there are discussions between the victims and inmates. ${ }^{390}$ While there is no available documented evidence of Canadian prison chaplains

\footnotetext{
${ }^{388}$ Wake, interview with the author, Ottawa, ON, April 26, 2005.

389 Ibid.

${ }^{390}$ Edwards, A., and Sharpe, S., "Restorative Justice in the Context of Domestic Violence: A Literature Review," Mediation and Restorative Justice Centre, Edmonton, Alberta, 2004, http://www.mrjc.ca/forms/CM\%20Documents/RJ-DV\%20Lit\%20Review\%20PDF.pdf at 8; for a description of a victim impact panel initiative in Alberta, including the personal testimony of one of the participating inmates, see "Rehabilitation options for impaired drivers in Alberta," University of Alberta, http://www.ualberta.ca/PAID/treatment.htm.
} 
participating in or facilitating victim impact panels, the involvement of prison chaplains in other jurisdictions ${ }^{391}$ suggests a realistic potential in this regard.

\section{Making the process more healing}

When engaging in, or prior to engaging in, actual restorative justice encounters, the prison chaplain consciously helps the inmate towards self-restoration, that is, he/she tries to repair what was broken in the offender. Rev. Wake admits to this as one of his goals, noting that he tries to at least to "plant seeds and walk with [inmates] for a while." 392

Likewise, the prison chaplain works at fostering an appropriate understanding of harm. During a restorative justice encounter, such as one of the conferencing approaches, the prison chaplain works to change the prisoner's understanding of his or her crime from having broken a rule or law into having committed harm against a person. According to Rev. Wake, inmates often feel that some of the crimes that they have committed are essentially victimless and there are no consequences for the people implicated or affected. $^{393}$ During the conference, Rev. Wake tries to get the inmate to understand the full implications of what has occurred. When he asks the inmate who is affected by the crime, it is not immediately obvious to the inmate that someone other than him/her feels repercussions. Together with the other participants in the conference, Rev. Wake tries to broaden the inmate's perspective. He tries to get him/her to understand how the direct victim and the other affected persons have been impacted by a crime. ${ }^{394}$ And he does not leave it at that. Rev. Wake also relates the incident and its effects to Biblical lessons,

\footnotetext{
${ }^{391}$ For an example, see Rebecca Evans, "An Innovative Concept: Victim Impact Panels at Lancaster CI," Correctional Compass May, 2000, http:/www.dc.state.fl.us/pub/compass/0005/page06.html.

${ }_{392}$ Wake, interview with the author, Ottawa, ON, April 26, 2005.

393 Ibid.

${ }^{394}$ Ibid.
} 
particularly the Ten Commandments and he ensures that his explanations are understood by the inmate. ${ }^{395}$ The goal is not to lecture the offender, but to teach him/her that his/her actions were wrong and why they were wrong, as well as to give the offender an opportunity to make it right. ${ }^{396}$

The mere presence of the prison chaplain in restorative justice engagements makes the process more healing and restorative. That is because of the way that the prison chaplain "manifests him/herself in the relationship as non-judgemental, with unconditional acceptance." 397 This has a very positive effect on the process because the inmate is better-able to relate to someone who is non-judgemental towards him/her. ${ }^{398}$ In a group setting, the inmates

drop their macho behaviour [...] because they trust the chaplain and they begin to trust the guys that they are with. [...] they know that they don't have to be afraid of being hurt and don't have to be afraid of being their vulnerable selves, which is where the pain is, their emotional pain. And they are able to express that and so that's really where the whole process of restorative justice can then really work because a person has to be in tune with his/her emotions in order to confront those who they have hurt. ${ }^{399}$

Therefore, the relationship that the prison chaplain tries to foster with the inmate is key. ${ }^{400}$ It is one in which there is a sense of trust, love and being cared for. ${ }^{401}$ This relationship allows the inmate to get in touch with sacredness, and also with his/her own emotions and vulnerability, and not cover these up when in the presence of others, especially those whom he/she has hurt. This is important because if the inmate covers up

\footnotetext{
${ }^{395}$ Ibid.

${ }^{396}$ Ibid

${ }^{397}$ Skaljin, interview with the author, Ottawa, ON, June 26, 2005.

${ }^{398}$ Ibid.

${ }^{399}$ Ibid.

${ }^{400}$ Ibid

${ }^{401}$ Ibid.
} 
his/her vulnerability in front of the victim, restorative justice becomes very difficult. ${ }^{402}$ In this regard, the prison chaplain's role is important.

When present at a restorative justice encounter, prison chaplains also have a role in identifying a positive and restorative way forward for the participants. They do this first by recognizing that everyone who has been affected by an offence must have input into finding appropriate solutions. When the chaplain is engaged in this stage of the process, his/her role is to facilitate the discussions through which the whole group decides on the right sanction. ${ }^{403}$

It has been demonstrated that prison chaplains are significant agents of restorative justice, both in terms of their natural, regular pastoral duties, as well as their unique contribution to restorative justice encounters involving inmates under their care.

\footnotetext{
402 Ibid.

${ }^{403}$ Wake, interview with the author, Ottawa, ON, April 26, 2005.
} 


\section{Chapter 5: Conclusion}

This thesis emerges from insufficient attention paid to the work of prison chaplains and inadequate attention devoted to the congruencies of prison chaplaincy and restorative justice. The aim of this thesis was to fill the existing gap. The thesis begins with a historical overview of restorative justice and prison chaplaincy. Specifically, it provides a review of restorative justice and its historical influences that are penetrated into modern restorative justice today. Likewise, it provides a historical review of prison chaplaincy. The third chapter provides an overview of restorative justice theory and outlines a theoretical guide against which the restorative role of prison chaplains is evaluated in Chapter 4.

The fourth chapter is assessed according to the theoretical criteria mapped out in Chapter 3. Also, interviews with prison chaplains, visiting chaplains, and professionals involved in the correction of prisoners, restorative justice experts and prison volunteers were applied in the chapter. Personal letters from prisoners were examined and integrated in this research. Overall, the interviews and letters provided a body of qualitative data that illustrated real-life examples shedding light on the parallels between restorative justice and the work of prison chaplains.

\section{Future research}

In the process of completing this thesis, it became apparent that more research needs to be completed, more empirical evidence needs to be collected and more clarification needs to be provided on restorative justice voluntary nature and its applications to real-life situations. This thesis uncovered some gray areas in the application of restorative justice 
which need to be addressed in the future research in order to provide a more clear understanding on the application of restorative justice.

\section{Limitations}

It is important to note that this thesis did not reflect unsuccessful experiences involving restorative justice processes nor the unsuccessful work of prison chaplains in the prison environment. However, by not discussing such my research does not suggest that there are not any. Given the purpose of this thesis, the methodological approach was geared to interview prison chaplains and their work in prisons. In order to collect data of unsuccessful and/or negative encounters involving prison chaplains, this research would have required additional participants in the interview process - prison inmates, which was beyond the scope of this research.

\section{Interpreting the findings}

From this research it became apparent when the general histories of prison chaplaincy and restorative justice are compared that there is a significant commonality between the motivations that underpin the emergence and development of each. Most striking is the spiritual imperative. Both restorative justice, with its roots in various faith traditions, and prison chaplaincy emerge from a genuine concern for the spiritual well-being of offenders and other affected persons. Pastoral care figures in the history of each, even if its presence today is more explicit in the current mandate of prison chaplains.

It became evident that concern for material well-being is also characteristic of the origins of both restorative justice and prison chaplaincy. While restorative justice 
focuses on the victim more so than does prison chaplaincy, it also attends to the material well-being of the offender, as demonstrated in the discussion on the influence of Judaism in restorative justice.

Further, restoration of the offender to society is likewise a goal rooted both in the origins of restorative justice and prison chaplaincy. Perhaps restorative justice has been more explicit in this regard by identifying the community and its members as participants in its various different practices. However, prison chaplaincy too has shown concern in this regard by specifically helping inmates prepare for re-entry into society. In addition to working to reform the offender so that he/she may re-enter society better aware of his/her responsibilities and as a good citizen, prison chaplains have historically tried to facilitate some communication between the prisoner and the outside.

While both restorative justice and prison chaplaincy have adapted in different ways to the prevailing justice system, both are motivated by a notion of an alternate path. It was demonstrated that restorative justice quite explicitly offers an alternative to conventional justice. Prison chaplaincy, though nested in an institution of the conventional justice system, also traditionally offers offenders means to transcend their sentence.

Both restorative justice (in its modern sense) and prison chaplaincy have shared many notions of the need for institutional reform. Most notably, both have been critical of the detriment of long periods of incarceration. In sum, the histories of restorative justice and prison chaplaincy reveal a commonality of motivations that underpin both movements. 
The various elements of restorative justice presented in this thesis - its main principles, goals, common models - together with considerations related to its application to the prison environment were intended to serve as a framework for evaluating the restorative roles of chaplains in two different contexts, that is the traditional correctional context and the formal restorative justice context. This framework was applied where I assembled the data on prison chaplains and highlighted the parallels with restorative justice.

The evidence assembled demonstrated a natural affinity between the work of prison chaplains and the principles and goals of restorative justice. It was found that in the course of their work, prison chaplains often have meaningful interaction with affected persons in addition to offenders. Likewise, prison chaplains have demonstrated to foster key moral and psychological changes within the offender. Namely, they lead inmates to the crucial step of self-restoration. Also, they work towards, and often succeed in, transforming the offender's perception of his/her crime from rule breaking to harm committed against individuals. A natural consequence of this is genuine remorse demonstrated by denunciation of the crime by the offender and concern for the fate of the victim. Prison chaplains help inmates develop a sense of obligation toward those who have been harmed, leading them to take responsibility for their actions and helping them map a positive, restorative way forward. Often, they facilitate inmates' desires to make reparations to their victims. As for the wrongs that the offender experiences as a result of his/her crime, that is, disrupted community networks, prison chaplains often attempt to assist in mending these relations and, in doing so, in essence practice restorative justice. The chaplain also has a degree of influence within the community and has a healing 
impact outside of prison. Prison chaplaincy helps lay the groundwork for the restoration of the inmate and in this way is an important implement of restorative justice.

The formal participation of prison chaplains in restorative justice was also discussed in this research. Because of their expertise in spiritual matters, it was found that prison chaplains are uniquely positioned to make a significant contribution to the conduct of restorative justice. Furthermore, their position within the institution accords them with an ability to arrange for restorative justice approaches for individual inmates under their pastoral care. Therefore, in various respects, the participation of the prison chaplain makes the process more healing and restorative.

It has been demonstrated in this thesis that prison chaplains are significant agents of restorative justice, both in terms of their natural, regular pastoral duties, as well as their unique contribution to restorative justice encounters involving offenders under their care. 


\section{Bibliography}

Adullam House Newsletter. (Queensland: Adullam House Fellowship Inc., September 2001), http://netministries.org/see/charmin/CM04371?frame=N.

Allard, Pierre and Northey, Wayne. "Christianity: the Rediscovery of Restorative Justice" in The Spiritual Roots of Restorative Justice (Albany: State University of New York Press, 2001), 119-141.

Allred, Robert. "Forgiving Again, Again" (1999) Sermon Archive, http://bobssermons.com/sermons/archive/990912.html.

Ammar, Nawal H. "Restorative Justice in Islam: Theory and Practice" in The Spiritual Roots of Restorative Justice (Albany: State University of New York Press, 2001), 161180.

Acorn, Annalise. Compulsory Compassion (UBS Press: Vancouver, 2004).

Al Sanousi, Haifa. The Psychological Role of Expressive and Literary Writing - A Case Study on Kuwaiti Women" PSYART, article 040706 (2004), http://www.clas.ufl.edu/ipsa/journal/articles/psyart/2004_sanousi01.shtml.

Ambrasas, K. J. "Labiausiai Paveikus yra Pavyzdys" [Most Effective is an Example] (January 23, 1996) Tèviškès Žiburiai.

Ambrasas, K. J. "Lietuvių Pèdsakai Kanadoje" [Lithuanian Footprints in Canada], Draugas (December 9, 1995).

“A welcome recidivist" (March/April 1983) Correctional Update, vol. 11, no. 1.

Bastiansen, Ria and Johan, Vercruysse. "Review of Restorative Justice in Belgium Prisons: Commentary on responding to the crisis" (2002) Prison Service Journal, no. 140, 18-19.

Bazemore, G., "Three Paradigms for Juvenile Justice" in Restorative Justice: International Perspectives, edited by Galway, B. and Hudson, J. (NY: Criminal Justice Press, 1996), 37-67.

Bazemore, G. "Crime Victims and Restorative Justice in Juvenile Courts: Judges as Obstacles or Leader" (1998) Western Criminology Review, vol. 1, no. 1, http//wcr.sonoma.edu/vln1/bazemore.html.

Bazemore, G. "Restorative Justice and Earned Redemption: Communities, Victims, and Offender Reintegration" (1998) American Behavioral Scientist vol. 41, no. 6, 768-813. 
Beckford, James A. and Sophie Gilliat. Religion in Prison: Equal Rites in a Multi-Faith Society (Cambridge: Cambridge University Press, 1998).

Blue, Arthur W. and Meredith A. Rogers Blue. "The Case for Aboriginal Justice and Healing: The Self Perceived through a Broken Mirror" in The Spiritual Roots of

Restorative Justice (Albany: State University of New York Press, 2001), 57-79.

Bradley, William J. Letter to Rev. Br. Justin Howson (April 10, 1982) in Behind the Prison Walls, Part One (Ottawa, 1997).

Braithwaite, John. "Restorative Justice: Assessing Optimistic and Pessimistic Accounts" (1999) Crime and Justice (The University of Chicago Press), vol. 25, 1-127.

Brunk, G. Conrad. "Restorative Justice and the Philosophical Theories of Criminal Punishment" in Michael L. Hadly, ed., The Spiritual Roots of Restorative Justice (Albany: State University of New York Press, 2001), 31-56.

Butler, Don. "How a Drunken Rampage Changed Legal History" Ottawa Citizen, (September 11, 2004).

Butler, Don. "Restorative justice processes fall into three broad categories, though increasingly they are being blended" Ottawa Citizen (September 11, 2004).

Caroline G. Nicholl. Toolbox for Implementing Restorative Justice and Advancing Community Policing, (US Department of Justice, 1999), http://nicic.org/Library/017741.

Case Study 1: "Maori of Aotearoa (New Zealand)" in Sustainable Social Relationships UNESCO

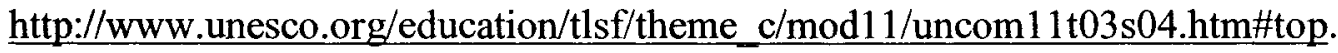

Chaplaincy Impact Study, http://www.cscscc.gc.ca/text/prgrm/chap/pastoral_care_report_e.shtml.

“Civil Society Organizations" Developing Ideas Digest (January, 1998), http://www.iisd.org/didigest/jan98/2jan98.html.

Cohen, Ronald L. "Provocations of Restorative Justice" (2001) Social Justice Research vol. 14 , no. 2 , 209-232.

Correctional Service of Canada. Role of Chaplains, http://www.cscscc.gc.ca/text/prgrm/chap/pro06-2_e.shtml.

Cooley, Dennis. Restorative Justice in Canada: Lessons Learned (Ottawa: Law Commission of Canada, 2002). 
Curran, L. Kathryn and Edward W. Mitchell. "Abstract" in Born-Again? The Meaning and Significance of Religious Rebirth in Prison,

http://www.asc41.com/www/1999/abscr094.htm.

Daly, Kathleen. "Restorative justice: The real story" (2002) Punishment and Society, vol. 4 , no. 1, 55-79.

Daly, Kathleen. "Revisiting the Relationship between Retributive and Restorative Justice" in Heather Strang and John Braithwaite, eds., Restorative Justice: Philosophy to practice (Aldershot: Ashgate Publishing Ltd., 2000), 33-54.

Daly, Kathleen. "Restorative Justice and Sexual Assault" (2006) British Journal of Criminology, no.46, 334-356.

Dammer, R. Harry. "Religion in Corrections" (2002) Encyclopedia of Crime and Punishment, vol. 3, http://academic.uofs.edu/faculty/DAMMERH2/ency-religion.html.

Damren, C. Samuel. "Restorative Justice: Prison and the Native Sense of Justice" (2002) Journal of Legal Pluralism, no. 47, 83-113.

Department of Justice Canada, Corrections and Conditional Release Act (1992), http://laws.justice.gc.ca/en/showtdm/cs/C-44.6///en.

“Des meurtriers, des voleurs et des..." (April 6, 1974) Le Droit.

Dominiquez, Cezar. Interview by Scott Schaffer, "I never achieved chocolate status': Conversations with a reformed convict" (2000) Journal of Mundane Behavior, vol. 1, no. 3 , http://mundanebehavior.org/issues/v1n3/dominguez.htm.

Dickson-Gilmore, Jane and La Prairie, Carol. Will the Circle be Unbroken? Aboriginal Communities, Restorative Justice, and the Challenges of Conflict and Change (University of Toronto Press, 2005).

Estrada-Hollenbeck, Mica. "Forgiving in the Face of Injustice: Victims' and Perpetrators' Perspectives" in Restorative Justice: International Perspectives edited by Galaway Burt and Hudson Joe. (Kugler Publications and Criminal Justice Press, 1996).

Eastern Mennonite University. Centre for Justice and Peace Building, http://www.emu.edu/ctp/little-rj.html.

Edgar, K. "Restorative justice in prison?" (1999) Prison Service Journal, no. 123, 6-7.

Edwards, Alan and Sharpe Susan. "Restorative Justice in the Context of Domestic Violence: A Literature Review" (2004) Mediation and Restorative Justice Centre, 
Edmonton, Alberta, http://www.mrjc.ca/forms/CM\%20Documents/RJ-

DV\%20Lit\%20Review\%20PDF.pdf.

Evans, Rebecca. "An Innovative Concept: Victim Impact Panels at Lancaster CI" (2000)

Correctional Compass, http://www.dc.state.fl.us/pub/compass/0005/page06.html.

"Evaluation Report: Chaplaincy EXCOM Presentation" (November, 2004) Correctional Service of Canada, http://www.csc-scc.gc.ca/text/PA/chaplaincy_deck_e.pdf.

"Examples of Government-Civil Society-World Bank Collaboration" The World Bank Group (2005), http://web.worldbank.org/WBSITE/EXTERNAL/TOPICS/CSO/0,contentMDK:2013812 7 pagePK:220503 piPK:220476 theSitePK:228717,00.html.

"Frequently Asked Questions" in Civil Society (Organization of American States), http://www.civil-society.oas.org/Pages/FAQ_ENG.htm.

Frankel, E. "Repentance Psychotherapy and Healing through a Jewish Lens" (1998) American Behavioral Scientist vol. 41, no.6, 814-833.

"Gender Equality and Peacebuilding: Lessons Learned" (2000) Canadian International Development Agency, http://www.acdicida.gc.ca/cida_ind.nsf/0/5c6765165f390eb585256a87000f6763?OpenDocument.

Glaser, Daniel. The Effectiveness of a Prison and Parole System (The Bobbs-Merrill Company, Inc. University of Illinois, 1964).

Guest, J. R. James. "Aboriginal Legal Theory and Restorative Justice, part 2" (1999) Justice as Healing vol. 4, no 2, http://www.usask.ca/nativelaw/publications/jah/guest2.html.

"Guidelines for Essential Services Agreements" Treasury Board Secretariat, http://www.tbs-sct.gc.ca/pubs_pol/hrpubs/TBM_11B/esa-ese01_e.asp.

Guidoni, V. Odillo. "The Ambivalence of Restorative Justice: Some Reflections on an Italian Prison Project" (2003) Contemporary Justice Review, vol. 6, no. 1, 55-68.

Hadley, L., Michael. "Introduction: Multifaith Reflection on Criminal Justice" in Michael L. Hadley, ed., The Spiritual Roots of Restorative Justice (Albany: State University of New York Press, 2001), 1-29.

Hannah-Moffat, Kelly. Punishment in Disguise: Penal Governance and Federal Imprisonment of Women in Canada (Toronto: University of Toronto Press, 2001). 
Helfgott, J. B., M. Lovell, C. Lawrence and W. Parsonage. "Development of the citizens, victims, and offenders restoring justice program at the Washington State Reformatory" Criminal Justice Policy Review, vol. 10, no. 3, 363-399.

Howard, Sharon. Early Modern Resources, http://www.earlymodernweb.org.uk/emr.

Huculak, Wilson and McWhinnie. "Restorative Justice Innovations in Canada" (2002) Behavioral Sciences and the Law vol. 20, 363-380.

Hudson, Barbara. "Beyond White Man's Justice: Race, Gender and Justice in Later Modernity" (2006) Theoretical Criminology, (University of Central Lancashire, UK, SAGE Publications, London) vol. 10 (1), 29-47.

Hudson, Barbara. "Restorative Justice and Gendered Violence: Diversion or Effective Justice?" (2002) British Journal of Criminology, vol. 42, 616-634.

Hudson, Barbara. "Restorative Justice: The Challenge of Sexual and Racial Violence" (1998) Journal of Law and Society, vol. 25, no. 2, 237-256.

International Perspectives on Restorative Corrections: A Review of the Literature (draft) Restorative Justice and Dispute Resolution Branch, Correctional Services Canada, 2005.

James, T. Canon. A Living Tradition: Penitentiary Chaplaincy. (Ottawa: Correctional Services of Canada, 1990).

Kleinotas, B. P. "Pasikalbejjimas su kalèjimo kapelionu" [Conversation with a prison chaplain], (May 22, 1987) Mūsu žinios vol. 5, no. 225.

Latimer, Jeff and Kleinknecht, Steven. The Effects of Restorative Justice Programming: A Review of the Empirical (Ottawa: Department of Justice Canada, 2000).

"Law, Victims and the Vulnerable" Prison Reform Trust, http://www.ws3.prisonreform.web.baigent.net/subsection.asp?id=708.

Liebmann, Marian and Stephanie Brathwaite. Restorative Justice in Custodial Settings: Report for the Restorative Justice Working Group in Northern Ireland (Restorative Justice Consortium, 1999), http://www.restorativejustice.org.uk/About_RJ/pdf/Restorative\%20justice\%20in\%20cust odial\%20settings_Marian\%20Liebmann\%20and\%20Stephanie\%20Braithwaite.pdf.

Llewellyn, Jennifer J. and Robert Howse. Restorative Justice: A Conceptual Framework, (Ottawa: Law Commission of Canada, 1998).

London, D. R., "The Restoration of Trust: Bringing Restorative Justice Reform from the Margins to the Mainstream" Criminal Justice Studies, vol.16, no. 3, 175-195. 
Lozoff, Bo and Fleet Maull. "Nation Behind Bars" Prison Dharma, vol. 3, no. 1 (2001), http://www.prisondharmanetwork.org/pdf_nwltr/nwlterspring01.pdf.

MacNeil, R. G. "Ex-prisoners and the church: Is enough being done?" The Citizen (July $23,1983)$.

Maginnis, Robert L. "Faith-Based Prison Programs Cut Costs and Recidivism" Family Research Council, http://www.heartland.org/pdf/13134a.pdf.

Marshall, Tony. "Restorative Justice: An Overview" Restorative Justice Consortium, Social Concern. (London, England, 1998), http://2ssw.che.umn.edu/rjp/Resources/Documents/bmar98a.PDF.

"Memorandum of Understanding between the Interfaith Committee on Chaplaincy and the Correctional Service of Canada" (2002) Correctional Service of Canada, http://www.csc-scc.gc.ca/text/prgrm/chap/mou_e.shtml.

Miers, D., Maguire, M., Goldie, S., Sharpe, S., Hale, C., Netten, A., Uglow, S., Doolin, K., Hallam,A., Enterkin, J., and Newburn, T. "An Exploratory Evaluation of Restorative Justice Schemes" Crime Reduction Research Series (2001) no. 9, http://www.homeoffice.gov.uk/rds/prgpdfs/crrs09.pdf.

Miller, D. Patrick. "Ten Questions for Validating Spiritual Paths, Groups, and Teachers: Part I" Peaceful Paths, http://www.peacefulpaths.com/cgibin/Web_store/web_store.cgi?page=sens0501.htm\&cart_id $=95214.3381$.

Ministry of Public Safety and Security (Ontario), Correctional Services Division, "Religious Services and Spiritual Care" in Adult Institutions: Policy and Procedures Manual, (July 2004).

Morris, Allison and Loraine Gelsthorpe. "Something Old, Something Borrowed, Something Blue, but Something New? A comment on the prospects for restorative justice under the Crime and Disorder Act 1998" (2000) Criminal Law Review, 18-30.

Morris, N. and Rothman, J. D. The Oxford History of the Prisons: the Practice of Punishment in Western Society, (Oxford University Press, 1998).

Nanji, Ghulam. "Faith in God not forgone at local detention centre" (April 26, 1980) Ottawa Journal.

National Chaplaincy Evaluation: Pastoral Care (Ottawa: Correctional Services of Canada, 2004), http://www.csc-scc.gc.ca/text/prgrm/chap/pastoral_care_report_e.shtml.

Newell, Tim. "Restorative Justice in Prisons" Restorative Justice Consortium, http://www.restorativejustice.org.uk/Resources/pdf/prisonrj.pdf. 
Newell, Tim. "Restorative Practice in Prisons: Circles and Conferencing in the Custodial Setting" (August, 2002) International Institute for Restorative Practices, http://restorativepractices.org/library/mn02/mn02 newell.html.

Northey, Wayne. "Spirituality Evaluation of Restorative Justice, Sixth International Conference on Restorative Justice "Best Practices in Restorative Justice" (June 4, 2003), http://www.sfu.ca/cfrj/fulltext/northey2.pdf.

Olson, M. Susan and Dzur, W. Albert. "Revisiting Informal Justice: Restorative Justice and Democratic Professionalism" Law and Society Review (2004), vol. 38, no. 1, 139176.

Palmas, Angelo (Archbishop). Letter to Fr. Victor Skilandziunas, February 29, 1980, in Victor Skilandziunas, Behind the Prison Walls (Part I), Ottawa, 1997.

Palmas, Angelo (Archbishop). Letter to Fr. Victor Skilandziunas, March 19, 1979, in Victor Skilandziunas, Behind the Prison Walls (Part I), Ottawa, 1997.

"Participant's Guide - Appendix" in Facilitating Restorative Group Conferences, Minnesota Department of Corrections, January 2003, http://www.doc.state.mn.us//rj/facilityconference/2003/PG\%207\%20App\%20-\%20103.pdf.

Pollard, Charles. "Victims and the Criminal Justice System: A New Vision" (2000) Criminal Law Review, 5-17.

Plourde, J. A. (Archbishop of Ottawa), Letter to Fr. Victor Skilandziunas, October 24, 1977, in Victor Skilandziunas, Behind the Prison Walls (Part I), Ottawa, 1997.

Pranis, Kay. Engaging the Community in Restorative Justice (St. Paul: University of Minnesota, 1998), http://2ssw.che.umn.edu/rjp/Resources/Documents/cpra98a.PDF.

"Prison Ministry - The Need Remains" Wisconsin Catholic Conference (February 25, 2002), http://www.wisconsincatholic.org/issuebrf/prison.htm.

Rabb, Peter. "Prison chaplain's life has rewards" (June 24, 1978) Ottawa Journal.

Rabey, Steve. 'Redeeming the Prisoners: Prison ministers embrace 'restorative justice' methods" (1999) Christianity Today,

http://www.ctlibrary.com/ct/1999/march1/9t3027.html.

"Restorative Justice in Canada: A Consultation Paper" (2000) Department of Justice Canada http://canada.justice.gc.ca/en/ps/voc/rjpap.html.

"Recent Research Bolsters Case for Addressing Spiritual Needs of Prisoners" (December 2003) Inside Out, http://www.pficjr.org/programs/apac/reports/InOutDec03.pdf. 
"Rehabilitation options for impaired drivers in Alberta" University of Alberta http://www.ualberta.ca/PAID/treatment.htm.

"Religious services and spiritual care" Adult Institutions Policy and Procedures Manual, (Ontario Ministry of Public Safety and Security, Correctional Services Division, July 2004).

Restorative Justice (John Howard Society of Albert, 1997), http://www.johnhoward.ab.ca/PUB/PDF/C26.pdf.

Robinson, H. Paul. "Should the Victims' Rights Movement Have Influence over Criminal Law Formulation and Adjudication?" (2002) McGeorge Law Review vol. 33, no. 4, 749-758.

"Role of Chaplains" Correctional Service of Canada, http://www.cscscc.gc.ca/text/prgrm/chap/pro06-2_e.shtml.

Sawatsky, Jarem. "A Shared JustPeace Ethic: Uncovering Restorative Values" (March 2002) Conciliation Quarterly vol. 20, no. 3

http://www.restorativejustice.org/articlesdb/articles/779/view?searchterm=holistic.

Schmid, J. Donald. Restorative Justice in New Zealand: A Model for U.S. Criminal Justice (Wellington: Fulbright New Zealand, 2001).

"Secretary General's Message at the Civil Society Forum" United Nations, Sao Paulo, June 2004, http://www.un.org/apps/sg/sgstats.asp?nid=977.

Segal, Eliezer. "Jewish Perspectives on Restorative Justice" in The Spiritual Roots of Restorative Justice (Albany: State University of New York Press, 2001), 181-197.

Šiūlyte, Rüta Ona. "Lietuvis kunigas tarp žmogžudžių," [Lithuanian priest among murderers], Ateitis (October 10, 1982), 345-347.

Skilandziunas, Victor. Behind the Prison Walls (Vilnius: Vilnius University Publishing House, 2003).

Skilandziunas, Victor. (1997) Behind the Prison Walls (Part One), Ottawa.

Skilandziunas, Victor. "Letter of recommendation and nomination of Sister Elisabeth Ann Kinsella and Mr. James P. Teehan for Community Service Award" in Behind the Prison Walls Part 1, (Ottawa: 1997).

Sundt, Jody L. and Francis T. Cullen. "The correctional ideology of prison chaplains: A national survey" (2002) Journal of Criminal Justice no. 30, 369-385. 
Sylvester, Douglas J. "Myth in Restorative Justice History" (2003) Utah Law Review no. 1, http://www.law.asu.edu/files/Programs/Sci-Tech/Commentaries/16Sylvester.pdf, 471522.

"Statement of Ethics" Correctional Service of Canada, http://www.csc-scc.gc.ca/text/prgrm/chap/soe_e.shtml.

Stutzman Amstutz, Lorraine and Howard Zehr. Victim Offender Conferencing: In Pennsylvania's Juvenile Justice System (Mennonite Central Committee, 1998), http://www.mcc.org/us/peaceandjustice/voc.pdf.

Spierenburg, P. "The Body and the State" in Mooris, N. and Rothman, J. D., The Oxford History of the Prison: The Practice of Punishment in Western Sociey, (Oxford University Press, 1995), 44-70.

Transforming Relationships Through Participatory Justice (Ottawa: Law Commission of Canada, 2003).

Umbreit, Mark S., Robert B. Coates and Betty Vos. "Restorative Justice versus Community Justice: Clarifying a Muddle or Generating Confusion?" (2004)

Contemporary Justice Review vol. 7, no. 1, 81-89.

Van Ness, W. Daniel. "Restorative Justice in Prisons" Restorative Justice Consortium (2005), http://www.restorativejustice.org.uk/Resources/pdf/RJ_in_Prisons_Dan_Van_Ness_05.p df.

Van Ness, W. Daniel. "An Overview of Restorative Justice Around the World" $11^{\text {th }}$ United Nations Congress on Crime Prevention and Criminal Justice, April 22, 2005.

James Waldram. The Way of the Pipe: Aboriginal Spirituality and Symbolic Healing in Canadian Prisons (Broadview Press, 1997).

Wemmers, Jo-Anne and Marisa Canuto. Victims Experiences With, Expectations and Perceptions of Restorative Justice: A Critical Review of the Literature (Montreal: Policy Centre for Victim Issues, 2002), http://www.justice.gc.ca/en/ps/rs/rep/2001/rr01-9.pdf.

Welch, Michael. Corrections: A Critical Approach $2^{\text {nd }}$ ed., (Boston: McGraw Hill, 2004).

Wilson, Robin J., Bria Huculak and Andrew McWhinnie. "Restorative Justice Innovations in Canada" (2002) Behavioral Sciences and the Law, vol. 20, 363-380.

"With a little imagination and a lot of courage" (2005) International Perspectives on Restorative Corrections: A Review of the Literature. CSC Draft, Restorative Justice and Dispute Resolution Branch. 
Zartman, I. William. "Prenegotiation: phases and functions," International Journal, (XLIV Spring 1989), 237-253.

Zehr, Howard and Mika, H. "Fundamental Concepts of Restorative Justice" in Restorative Justice On-Line Notebook (U.S. Department of Justice, 1997), http://www.ojp.usdoj.gov/nij/rest-just/ch1/fundamental.html.

Zehr, Howard. The Little Book of Restorative Justice (Intercourse: Good Books, 2002).

\section{List of participants:}

Allarrd, Pierre. Assistant Commissioner for Community Engagement at the Correctional Service of Canada (CSC). Interview with the author, Ottawa, ON. April 8, 2005.

Bonneville, Bruno. Executive Director of the Law Commission. Interview with the author, Ottawa, ON. April 18, 2005.

Fritz, Clarke. Director, Community Re-Integration CSC/OMCSRC. Private consultation by the author, Ottawa, ON. August 17, 2005.

Harris, Scott. Director, Restorative Justice and Dispute Resolution Division at the Correctional Service of Canada (CSC). Interview with the author, Ottawa, ON. April 11, 2005.

Landry, Michelle. Correctional Service of Canada (CSC). Private consultation by the author, Ottawa, ON. November 22, 2005.

Moorhead, Bev. Volunteer at the Ottawa Carleton Detention Centre. Interview with the author, Almont, ON. September 15, 2005.

Schroeder, Stuart. Ontario Multifaith Council. Interview with the author, Scarborough, ON. April 4, 2005.

Scott, Sandra. Volunteer at the Ottawa Carleton Detention Centre. Interview with the author, Almont, ON. September 15, 2005.

Skaljin, Michael. Manager Re-integration program, Ontario Multifaith Council. Interview with the author, Ottawa, ON. June 26, 2005.

Skanks, E. Paul. Traditional Mohawk Nation Teacher. Interview with the author, Ottawa, ON. September 12, 2006.

Skilandziunas, Victor. Retired Chaplain worked at the Ottawa Carleton Detention Centre. Interview with the author, Ottawa, ON. November, 18, 2003. 
Wake, Carl. Chaplain at the Ottawa Carleton Detention Centre. Interview with theauthor, Ottawa, ON. April 26, 2005. 


\section{Appendix A}

\section{Letter of Information to Prison Chaplains (former and present)}

Dear,

My name is Jurgita Rushkyte and I am inviting you to participate in my research project. I am currently working on my thesis for a Master's degree in Legal Studies at Carleton University. The aim of my research project is to broaden and enrich the knowledge and understanding of prison chaplains whose work and dedication are greatly understudied. A portion of the research will examine how prison chaplains apply the principles of restorative justice in the correctional system.

As a student in a socio-legal studies program, I am very interested in examining the congruency between prison chaplains and the principles of restorative justice in Canada. In order to effectively pursue this topic, it is crucial to listen to the first-hand experiences, viewpoints and perspectives of prison chaplains who are less-noticed, yet dedicated participants in the promotion and implementation of restorative justice principles in their work environment. In order to gain a well rounded understanding of what is going on behind the prison walls, I am hoping to conduct interviews with detention center chaplains who are dedicated in helping inmates, their families, the victim of the crime and their families, and the community at large.

Interview will take maximum 60 minutes and will be tape recorded, with your permission. However, in the event, where you decline to be tape-recorded during the interview, the interview will be recorded on paper. The interview will take place at a time and location convenient to you. The interview will be informal in nature with openended questions. During the interview, you have the right to refuse to answer any question and can withdraw from the study at anytime during the data gathering portion of the research. Should you decide to withdraw from the study you may decide at that time if I may use the information you have provided to that point. The tape recorded interview will be destroyed by me when the information is transcribed and the remaining information will remain stored in a secure computer and file cabinet in my home office.

Due to the nature of the research, there will be very minimal risk involved in participating in this study. The risks involved in this research could include of an emotional nature as I will be asking you about your experiences and opinions about the prison system and your experience with restorative justice movement. Openly discussing the nature of your work could be emotionally exhausting. Also, openly discussing views about the Canadian justice system, which may not concur with the policy of the employer, might lead to potential negative job-related consequences. As the primary researcher, I will take all the steps needed to minimize any potential risks to participants. 
As the topics on prison chaplaincy and restorative justice are openly discussed and because the subject is so small, I cannot offer anonymity to any participant in this study. I can ensure a degree of confidentiality and offer full respect for those willing to express their views. I will take precautions to ensure confidentiality, even though quotations and comments derived from the interviews will be used as a part of a qualitative case study for a public document.

I am not planning on conducting any follow-up interviews or sessions. The finished project will be available to participants upon their requests. This project has been reviewed and has received ethics clearance through the Carleton University Research Ethics Committee. If you have any concerns or questions about their involvement in this study you may contact the ethics committee chair, Prof. Antonio Gualtieri at (613) 520- 2517 or by email: ethics@carleton.ca

I would like to thank you for your time and cooperation. If you have any further questions regarding this study please do not hesitate to contact me at (613) 521-5526 or my supervisor, Prof. Dawn Moore at (613) 520-2600, ext. 3823.

Sincerely,

Jurgita Rushkyte 
Signature of Participant

Date
Signature of Researcher

Date 
Appendix B

\section{Letter of Information to Government Employees and Other Participants in the Restorative Justice}

Dear,

My name is Jurgita Rushkyte and I am inviting you to participate in my research project. I am currently working on my thesis for a Master's degree in Legal Studies at Carleton University. The aim of my research project is to broaden and enrich the knowledge and understanding of prison chaplains whose work and dedication are greatly understudied. A portion of the research will examine how prison chaplains apply the principles of restorative justice in the correctional system.

As a student in a socio-legal studies program, I am very interested in examining the congruency between prison chaplains and the principles of restorative justice in Canada. In order to effectively pursue this topic, it is crucial to listen to the first-hand experiences, viewpoints and perspectives of people who are the catalysts in the promotion and implementation of restorative justice principles. In order to gain a well rounded understanding of what is going on 'on the ground', I am hoping to conduct interviews with people involved in promoting the principles of restorative justice in Canada.

Interview will take maximum 60 minutes and will be tape recorded, with your permission. However, in the event, that you decline to be tape-recorded during the interview, the interview will be recorded on paper. The interview will take place at a time and place convenient to you. The interview will be informal in nature with openended questions. I will be asking you about your perspectives on the implementation of the principles of restorative justice, its effectiveness and its effects on the Canadian justice system. During the interview, you have the right to refuse to answer any question and can withdraw from the entire study. Should you decide to withdraw from the study you may decide at that time if I may use the information you have provided to that point. Tape recorded interviews will be destroyed when the information is transcribed by me and the remaining information will remain stored in a secure computer and file cabinet in my home office.

Due to the nature of the research, there will be very minimal risk involved in participating in this study. Although, very minimal, there is a possibility for professional risks for partaking in this study. Openly discussing views about the Canadian justice system and opinions about restorative justice movement, which may not concur with the policy of the employer, might lead to potential negative job-related consequences. As the primary researcher, I will take all the steps needed to minimize any potential risks to participants.

As the topics on prison chaplaincy and restorative justice are openly discussed, and because the subject is very small, I cannot offer anonymity to any participant in this 
study. I can offer full respect for those willing to express their views, however quotations and comments derived from the interview will be used as a part of a qualitative case study for a public document.

Since this is a student project, I am not planning on conducting any follow-up interviews or sessions. The finished project will be available to participants upon their requests. This project has been reviewed and has received ethics clearance through the Carleton University Research Ethics Committee. If you have any concerns or questions about their involvement in this study you may contact the ethics committee chair, Prof. Antonio Gualtieri at (613) 520- 2517 or by email, ethics@carleton.ca.

I would like to thank you for your time and cooperation. If you have any further questions regarding this study please do not hesitate to contact me at (613) 521-5526 or my supervisor Prof. Dawn Moore at (613) 520-2600, ext. 3823.

Sincerely,

Jurgita Rushkyte 
If I have further questions or concerns about this study I can contact Prof. Antonio Gualtieri, Chair of the Carleton University Research Ethics Committee at (613) 520-2517 or at ethics@carleton.ca

I have been informed of the purpose of this study on Restorative Justice and the role of prison chaplains in Canada. I have also had the opportunity to have any questions answered by the researcher. I agree to be interviewed by Jurgita Rushkyte and understand my rights as an interviewee.

Signature of Participant

Date
Signature of Researcher

Date 